Türkiye Jeoloji Bülteni
Geological Bulletin of Turkey
$60(2017) 383-432$
doi:10.25288/tjb.327047

\title{
Taxonomy and Distribution of Recent Benthic Foraminifera from Bir Ali Beach, Shabwah Governorate, Arabian Sea, Yemen
}

\author{
Mohammed Al-Wosabi ${ }^{1,2 *} \mathbb{D}$, Munef Mohammed $^{3} \mathbb{D}$, Fahad Basardah ${ }^{4} \mathbb{D}$ \\ ${ }^{I}$ Earth and Environmental Sciences Dept., Faculty of Science, Sana'a University, Yemen, \\ PO. Box: 11903 Sana'a \\ ${ }^{2}$ Current Address: Visiting Professor, Dept. Earth Sci., Col. Sci., Sultan Qaboos University, Oman \\ ${ }^{3}$ Earth and Environmental Sciences Dept., Faculty of Science, Sana'a University, Yemen \\ ${ }^{4}$ Oil and Gas Department, Faculty of Oil and Minerals, University of Aden, Shabwah, Yemen,
}

Geliş/Received : 21.02.2017 • Düzeltilmiş Metin Geliş/Revised Manuscript Received : 21.05.2017 • Kabul/Accepted : 09.06.2017 • Basku/Printed : 01.08.2017 Araştırma Makalesi/Research Article Türkiye Jeol. Bül. / Geol. Bull. Turke

\begin{abstract}
One hundred and eleven benthic foraminiferal species belonging to 36 genera, 25 families, 16 superfamilies and 4 suborders were identified from twenty samples collected from Bir Ali beach on the Yemeni Arabian Sea coastline. The benthic foraminifera assemblages were dominated by species belonging to Miliolina suborder with 71 species and 17 genera, followed by Rotaliina with 29 species and 14 genera, Textulariina 9 species and 3 genera and Lagenina 2 species and 2 genera. The distribution of recent shallow-water benthic foraminifera in surface sediment samples is in varians from sample to another. Higher abundance of genus Quinqueloculina is recorded in almost all the samples of the study area. The recorded assemblages show a high similarity to the foraminiferal assemblages of the IndoPacific region, East African coast and Red Sea.
\end{abstract}

Key Words: Arabian Sea, Bir Ali Beach, Recent benthic foraminifera, Shabwah, Yemen

\section{INTRODUCTION}

The Arabian Sea represents a tropical region of high priority, as it is one of the richest marine biological areas of the world. It is a major contributor to global ocean productivity and biogenic carbonate burial; It is therefore currently under intensive study to understand its role in both modern and palaeoenvironmental global ocean/climate system (Seears, 2011). The Arabian Sea is known to harbour a wide range of benthic foraminiferal morphospecies (Brummer and Kroon, 1988). This sea is a classical region for investigations in foraminifera taxonomy. Numerous researchers studied the foraminiferal diversity of the Arabian sea (i.e. Chapman,1895; Hofker,1927; Stubbings,1939; Rao, 1970; Nigam et al., 1979; Setty and Nigam, 1980; Cherif et al., 1997; Kurbjeweit et al., 2000; Erbacher and Nelskamp, 2006 and Sarkar and Gupta, 2009). The first study of benthic foraminifera in Arabian Sea goes back to the time of Chapman (1895) who reported 274 species of foraminifera from the Arabian Sea. This is followed by a monograph of foraminifera collected from the Arabian Sea published by Hofker (1927). Stubbings (1939) recorded about 300 species from the same area. Sarkar and Gupta 
(2009) recorded 201 benthic foraminifera species from southeastern Arabian Sea. Al-Wosabi et al. (2011) reported 86 foraminiferal species from Socotra Island, Indian Ocean, Yemen.

This study aims to introduce the classification of the benthic foraminifera assemblages and their surface distribution in the recent sediments from the Bir Ali beach, Yemeni Arabian Sea coastline (Figure 1).

\section{STUDY AREA}

Bir Ali Beach is choosen for this study due to its important location as a port for oil and gas export. The study area is located in the south-east part of Yemen, between $14^{\circ} 01^{\prime} \mathrm{N}$ and $48^{\circ} 20^{\prime} \mathrm{E}$ (Figure 1). This area is covered by basaltic rocks of Neogene and Quaternary age and has been defined as "Aden Volcanic Series" (Beydoun, 1966). Several large volcanic cones composed of

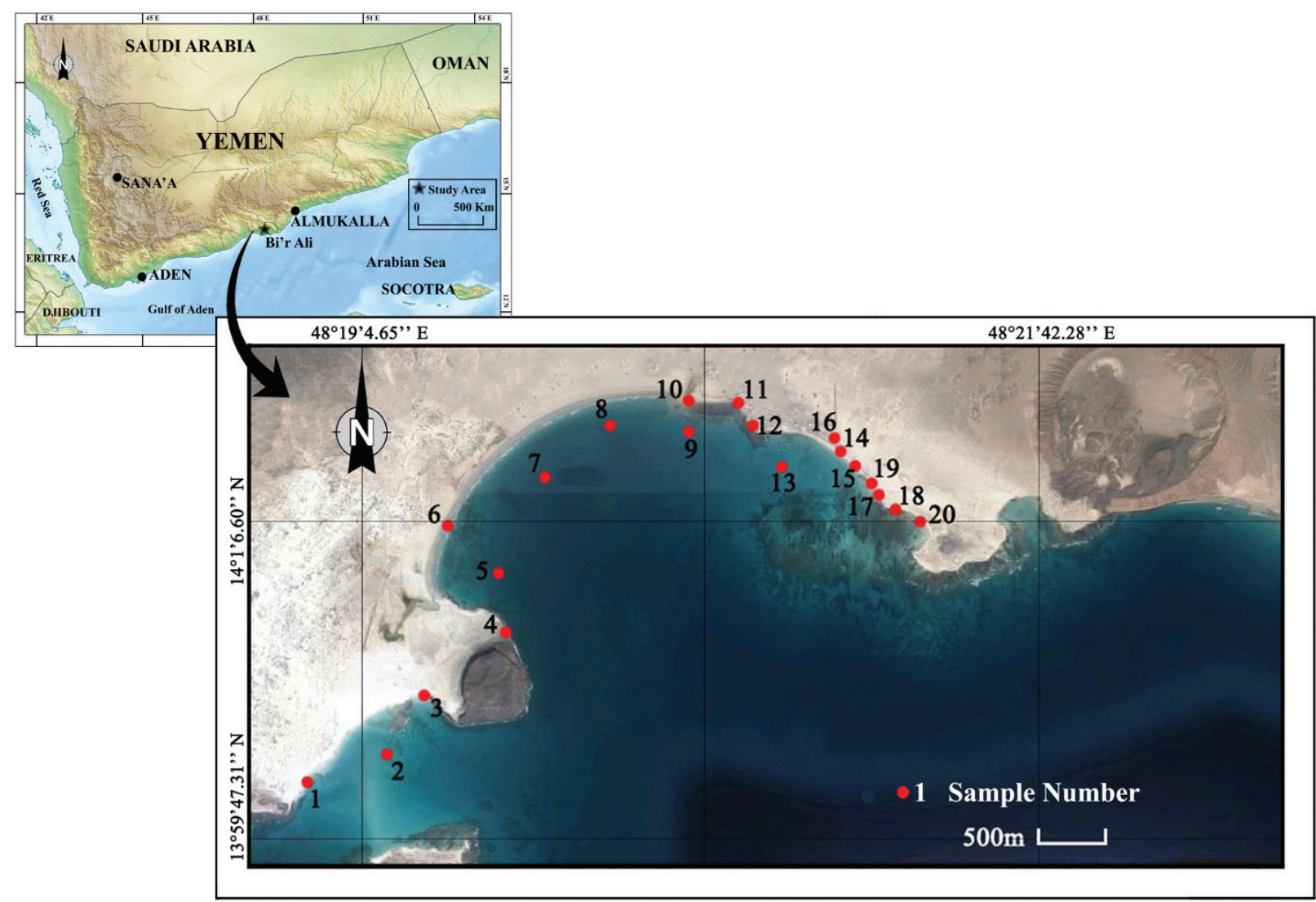

Figure 1. Location map of collected samples (After Google Earth and http://www.Maps-of-the-world.net/maps-of-/ asia/maps-of-yemen, with modification) 
light coloured and well-bedded basaltic tuffs align at the offshore parallel to the coastal sand of the land. The volcanic cones are restricted to the rift zone of the Gulf of Aden, characterized by a high volcanic activity. In the near coast areas, parts of the basaltic rocks are covered by thin sheets of blowing sand or by gritty-silty (tuff) weathering products, which may have considerably flattened the original rough surface. Parts of the cliff-coast are plained by abrasional processes of the sea and occurrences of beach rock, coral, or wave-cut platforms and small cliffs are frequent at levels of 5 to 7 meters above sea level (Fantozzi and Sgavetti, 1998).

The climate of the study area is tropicarid. It is essentially affected by the monsoon winds of the Indian Ocean. The Arabian Sea is a unique marine environment since its circulation is completely reversed biannually by seasonally reversing monsoon winds. It is therefore subject to greater seasonal variability than any other ocean basin on the globe (Clemens et al., 1991). This area is characterized by low and irregular rainfall (less than $50 \mathrm{~mm} / \mathrm{y}$ ) where the drainage system consists of dry watercourses, of wadis, which flow only episodically in times of torrential runoff after heavy rains (Caton-Thompson and Gardner, 1939).

\section{METHODOLOGY}

In the present study, twenty recent sediment samples were collected from the beach of Bir Ali area with depth ranging between $0.5-5 \mathrm{~m}$ (Figure 1). 100 grams of each sample were treated for extracting the foraminiferal tests. The sample immersed in water mixed with hydrogen peroxide (10\% conc.), and were boiled for about 5 hours to remove the organic materials, the clay, silt, and fine sand from the foraminiferal tests. By sterring the material with salty water in a plastic container and according to the difference in the density, the sediment sunk and the foraminiferal tests still suspended or floated for a short time. Repeating this method, most of the foraminiferal tests were separated from the other sample components, and then collected in a glass tubes. A binocular light microscope has been used to examine and identify the foraminiferal tests to the species level. These species are coated with gold using Blazer sputtering equipment (EMITECH, K550X sputter coater), and photographed using the scanning electron microscope (SEM) Model Philips XL 30, in the SEM Unit at the Egyptian mineral resources authority (Central Laboratories Sector), Geza Egypt.

\section{SYSTEMATIC PALEONTOLOGY}

Systematic classification of foraminiferal species has been accomplished according to their morphological features such as shell shape, wall composition and structure, chamber shape and numbers and other features. The systematic classification of the recorded foraminiferal assemblages here has been done according to Loeblich and Tappan, 1988; Kaminski, 2004 and Ellis and Messina, 1940 and their supplements as well as related publications in different scientific relevant journals. The distribution of the the species through the samples was determined and displayed in Table 1. In this paper, the description of species restricted to unknown species, whereas the description of identified species is similar to their identical type species. In case there are differences between present identified species and the type species, these differences will be shown in the remarks. All the illustrated specimens and sediment samples utilized for this study have been indexed and deposited in the repository of the Earth and Environmental Sciences Department, Faculty of Science, Sana'a University. 
Table 1. Distribution of identified foraminifera species from the study area.

\begin{tabular}{|c|c|c|c|c|c|c|c|c|c|c|c|c|c|c|c|c|c|c|c|c|c|}
\hline No & Species $\quad$ Stations & 1 & 2 & 3 & 4 & 5 & 6 & 7 & 8 & 9 & 10 & 11 & 12 & 13 & 14 & 15 & 16 & 17 & 18 & 19 & 20 \\
\hline 1 & $\begin{array}{l}\text { Spiroplectinella } \\
\text { sagittula }\end{array}$ & & A & & & A & & & & $\mathrm{A}$ & & & & & & & & & & & \\
\hline 2 & S. sp. & & & & & $\mathrm{F}$ & & & & & & & $\mathrm{R}$ & $\mathrm{F}$ & & $\mathrm{F}$ & & & & & \\
\hline 3 & Gaudryina rudis & & $\mathrm{A}$ & $\mathrm{F}$ & & A & & & & & & & & $\mathrm{F}$ & & & & & & & \\
\hline 4 & $\begin{array}{l}\text { Textularia } \\
\text { agglutinans }\end{array}$ & & A & $\mathrm{F}$ & & $\mathrm{R}$ & & & $\mathrm{R}$ & $\mathrm{A}$ & & & & A & & & & $\mathrm{A}$ & & & \\
\hline 5 & T. candeiana & & & $\mathrm{C}$ & $\mathrm{C}$ & & & & & $\mathrm{A}$ & & & & $\mathrm{C}$ & $\mathrm{A}$ & & & & & & \\
\hline 6 & T. conica & & $\mathrm{F}$ & & & $\mathrm{F}$ & & & & & & & $\mathrm{F}$ & $\mathrm{C}$ & & & & & & & $\mathrm{C}$ \\
\hline 7 & T. gramen & & A & & & $\mathrm{R}$ & & $\mathrm{R}$ & & & & & $\mathrm{F}$ & $\mathrm{R}$ & & & & & $\mathrm{F}$ & & \\
\hline 8 & T. sp.1 & $\mathrm{F}$ & & & & $\mathrm{F}$ & & $\mathrm{R}$ & & & & & $\mathrm{F}$ & $\mathrm{R}$ & & & & & $\mathrm{F}$ & & \\
\hline 9 & T. sp.2 & & $\mathrm{A}$ & & & $\mathrm{A}$ & & & & & & & & $\mathrm{C}$ & & & & & & & \\
\hline 10 & $\begin{array}{l}\text { Planispirinella } \\
\text { exigua }\end{array}$ & & & $\mathrm{C}$ & & $\mathrm{C}$ & & & & & & & & $\mathrm{C}$ & & & & & & & \\
\hline 11 & Adelosina laevigata & & $\mathrm{C}$ & & & & & $\mathrm{C}$ & $\mathrm{C}$ & & & & & $\mathrm{C}$ & & & & & & & \\
\hline 12 & A. mediterranensis & & & & & $\mathrm{F}$ & $F$ & & & & & & & $\mathrm{~F}$ & & & & & & & $\mathrm{~F}$ \\
\hline 13 & A. $\mathrm{sp}$ & & & & & $\mathrm{C}$ & & & $\mathrm{R}$ & & & & & $\mathrm{R}$ & & & $\mathrm{C}$ & & & $\mathrm{C}$ & \\
\hline 14 & Cribrolinoides curta & $\mathrm{C}$ & $\mathrm{C}$ & & & $\mathrm{C}$ & & & & A & & & & & & & & & & & \\
\hline 15 & \begin{tabular}{|l}
$\begin{array}{l}\text { Spiroloculina } \\
\text { acutimargo }\end{array}$ \\
\end{tabular} & $\mathrm{A}$ & $\mathrm{F}$ & & & & & & & & & & $\mathrm{F}$ & A & A & & & & & & \\
\hline 16 & S. аеqua & & $\mathrm{C}$ & & & $\mathrm{C}$ & & & & & & & & $\mathrm{R}$ & & & & $\mathrm{C}$ & $\mathrm{R}$ & & \\
\hline 17 & S. antillarum & & $\mathrm{A}$ & & & $\mathrm{F}$ & & & & $\mathrm{F}$ & & & & $\mathrm{A}$ & $\mathrm{A}$ & & & & & & \\
\hline 18 & S. communis & $\mathrm{F}$ & & & & $\mathrm{F}$ & & & & & & & & & & $\mathrm{F}$ & & & & & \\
\hline 19 & S. depressa & & $\mathrm{C}$ & & & $\mathrm{R}$ & & & & $\mathrm{C}$ & & $\mathrm{R}$ & & $\mathrm{C}$ & & & & & & & $\mathrm{C}$ \\
\hline 20 & S. elegans & & $\mathrm{F}$ & & & $\mathrm{F}$ & & & & $\mathrm{F}$ & & & & $\mathrm{R}$ & & & & $\mathrm{R}$ & & & \\
\hline 21 & S. tenuiseptata & & $\mathrm{C}$ & & & & & & & $\mathrm{C}$ & & & & $\mathrm{C}$ & & & & & & & \\
\hline 22 & S. sp.1 & $\mathrm{C}$ & & & & $\mathrm{C}$ & & & & & & & & $\mathrm{C}$ & & & & & $\mathrm{C}$ & & \\
\hline 23 & S. sp.2 & & & & & $\mathrm{R}$ & & & & & $\mathrm{R}$ & & & $\mathrm{F}$ & & & & & & $\mathrm{F}$ & \\
\hline 24 & \begin{tabular}{|l|}
$\begin{array}{l}\text { Siphonaperta } \\
\text { agglutinans }\end{array}$ \\
\end{tabular} & & A & & & $\mathrm{F}$ & & & $\mathrm{F}$ & & & & & & & & & A & & & A \\
\hline 25 & S. horrida & & $\mathrm{A}$ & & & $\mathrm{C}$ & & & $\mathrm{C}$ & & & & & & & $\mathrm{C}$ & & & & $\mathrm{C}$ & \\
\hline 26 & S. irregularis & & $\mathrm{A}$ & & & $\mathrm{R}$ & & & & & & & A & $\mathrm{R}$ & & & & & & & \\
\hline 27 & Hanerina diversa & & $\mathrm{A}$ & & & $\mathrm{R}$ & & & & & & & & $\mathrm{A}$ & & & $\mathrm{C}$ & & & & $\mathrm{C}$ \\
\hline 28 & $\begin{array}{l}\text { Quinqueloculina } \\
\text { agglutinata }\end{array}$ & $\mathrm{R}$ & A & & & A & & & & A & & & & & $\mathrm{R}$ & & & A & & & \\
\hline 29 & Q. bradyana & & $\mathrm{C}$ & & & & & $\mathrm{C}$ & & & & & & $\mathrm{C}$ & & & & & & & \\
\hline 30 & Q. carinatastriata & & $\mathrm{A}$ & & & A & & & $\mathrm{A}$ & $\mathrm{R}$ & & & $\mathrm{A}$ & $\mathrm{R}$ & & & & & $\mathrm{A}$ & & \\
\hline 31 & Q. corrugate & & $\mathrm{C}$ & & & A & $\mathrm{C}$ & & & & & & & $\mathrm{A}$ & & & & $\mathrm{A}$ & & & \\
\hline 32 & Q. debenayi & & $\mathrm{F}$ & & & A & & $\mathrm{F}$ & & & & & & $\mathrm{A}$ & & & & & $\mathrm{F}$ & & \\
\hline 33 & Q. granulocostata & & & A & & $\mathrm{C}$ & & A & $\mathrm{C}$ & & & & $\mathrm{A}$ & $\mathrm{C}$ & & & & & & & $\mathrm{A}$ \\
\hline 34 & Q. jugosa & & $\mathrm{A}$ & & & A & & & & $\mathrm{C}$ & & & & $\mathrm{A}$ & $\mathrm{C}$ & & & & & & \\
\hline 35 & Q. lamarckiana & & A & & & $\mathrm{R}$ & & $\mathrm{A}$ & & & $\mathrm{A}$ & & & & $\mathrm{R}$ & & & & & & \\
\hline 36 & Q. lata & & $\mathrm{C}$ & & & & & & & $\mathrm{C}$ & & & & $\mathrm{C}$ & & & & & & & $\mathrm{C}$ \\
\hline 37 & Q. multimarginata & & $\mathrm{A}$ & $\mathrm{F}$ & & $\mathrm{A}$ & & & $\mathrm{F}$ & & $\mathrm{A}$ & & & $\mathrm{F}$ & & & & $\mathrm{A}$ & & & \\
\hline 38 & Q. neapolitana & & $\mathrm{F}$ & & & $\mathrm{F}$ & & & & & $\mathrm{R}$ & & & $\mathrm{R}$ & & & & & & & \\
\hline 39 & Q. padana & & $\mathrm{R}$ & & & $\mathrm{R}$ & & $\mathrm{C}$ & & $\mathrm{C}$ & & & & $\mathrm{C}$ & & & & & $\mathrm{C}$ & & \\
\hline 40 & Q. parkeri & & $\mathrm{F}$ & $\mathrm{A}$ & & $\mathrm{F}$ & & & & & & $\mathrm{A}$ & & $\mathrm{F}$ & & & & $\mathrm{F}$ & & & $\mathrm{A}$ \\
\hline 41 & Q. plicosa & & $\mathrm{A}$ & & & $\mathrm{R}$ & & & & $\mathrm{A}$ & & $\mathrm{R}$ & & $\mathrm{A}$ & & & & & & & \\
\hline
\end{tabular}




\begin{tabular}{|c|c|c|c|c|c|c|c|c|c|c|c|c|c|c|c|c|c|c|c|c|c|}
\hline 42 & Q. poeyana & & $\mathrm{C}$ & & & $\mathrm{A}$ & & & $\mathrm{C}$ & & & A & & $\mathrm{C}$ & & & & & & & \\
\hline 43 & Q. pseudoreticulata & & $\mathrm{A}$ & & & $\mathrm{R}$ & & A & & & & & & $\mathrm{R}$ & & $\mathrm{A}$ & & & & & \\
\hline 44 & Q. cf. Q. rugosa & & $\mathrm{A}$ & & & $\mathrm{A}$ & & & & & & & & $\mathrm{F}$ & & & & & $\mathrm{F}$ & & \\
\hline 45 & Q. seminulum & & $\mathrm{A}$ & & & $\mathrm{A}$ & $\mathrm{C}$ & & & $\mathrm{A}$ & $\mathrm{C}$ & & & $\mathrm{C}$ & & & & & $\mathrm{A}$ & & $\mathrm{C}$ \\
\hline 46 & Q. subpolygona & $\mathrm{A}$ & $\mathrm{A}$ & & & $\mathrm{F}$ & & $\mathrm{A}$ & & & $\mathrm{F}$ & & & $\mathrm{F}$ & & & & & $\mathrm{A}$ & & \\
\hline 47 & Q.cf. Q. triangularis & & $\mathrm{R}$ & & & $\mathrm{R}$ & & & $\mathrm{C}$ & & & & & $\mathrm{C}$ & & & & & & & $\mathrm{C}$ \\
\hline 48 & Q. triangula & & $\mathrm{A}$ & & & $\mathrm{A}$ & & & & $\mathrm{F}$ & & & $\mathrm{A}$ & $\mathrm{F}$ & & & $\mathrm{A}$ & & & & \\
\hline 49 & Q. undulosecostata & $\mathrm{A}$ & & & & $\mathrm{R}$ & & & $\mathrm{A}$ & & & & $\mathrm{A}$ & $\mathrm{R}$ & & & & & & & $\mathrm{R}$ \\
\hline 50 & Q. vulgaris & & $\mathrm{A}$ & & & $\mathrm{A}$ & & $\mathrm{R}$ & & & & & & $\mathrm{R}$ & & $\mathrm{R}$ & & & $\mathrm{A}$ & & \\
\hline 51 & Q. sp. 1 & & $\mathrm{~A}$ & & & A & & & & $\mathrm{F}$ & & & & $\mathrm{F}$ & $\mathrm{F}$ & & & $\mathrm{A}$ & & $\mathrm{F}$ & \\
\hline 52 & Q. sp.2 & & $\mathrm{A}$ & & & $\mathrm{A}$ & & & & & & & & $\mathrm{R}$ & & & & $\mathrm{R}$ & & & \\
\hline 53 & $\begin{array}{l}\text { Miliolinella } \\
\text { subrotunda }\end{array}$ & & A & & & $\mathrm{R}$ & & A & & $\mathrm{R}$ & & & & $\mathrm{R}$ & & & & & & & \\
\hline 54 & M.sp. & & $\mathrm{F}$ & & & $\mathrm{F}$ & & & & & $\mathrm{F}$ & & & $\mathrm{F}$ & & & & & & & \\
\hline 55 & $\begin{array}{l}\text { Pseudomassilina } \\
\text { pacificiensis }\end{array}$ & & $\mathrm{R}$ & & & & & $\mathrm{R}$ & & & & & $\mathrm{R}$ & $\mathrm{R}$ & & & & & & & \\
\hline 56 & Pyrgo oblonga & & $\mathrm{R}$ & & & $\mathrm{R}$ & & & & & & & & $\mathrm{R}$ & & & & & & & $\mathrm{R}$ \\
\hline 57 & P. sp. & & $\mathrm{F}$ & & & $\mathrm{F}$ & & & & & & & & $\mathrm{F}$ & & & & $\mathrm{F}$ & & & \\
\hline 58 & Triloculina affinis & & & & & $\mathrm{R}$ & & $\mathrm{R}$ & & & & & & $\mathrm{R}$ & & & & & & & $\mathrm{R}$ \\
\hline 59 & T. brongniatiana & & $\mathrm{A}$ & & & $\mathrm{F}$ & & & & $\mathrm{A}$ & & & & $\mathrm{F}$ & & & & & & $\mathrm{A}$ & \\
\hline 60 & T. elongotricarinata & & $\mathrm{A}$ & & & $\mathrm{R}$ & & & & & & & & $\mathrm{A}$ & & & $\mathrm{R}$ & & & & \\
\hline 61 & T. fichteliana & & $\mathrm{C}$ & & $\mathrm{C}$ & $\mathrm{C}$ & & & & & & & & $\mathrm{C}$ & & & & & & & \\
\hline 62 & T. insignis & & $\mathrm{A}$ & & & $\mathrm{R}$ & $\mathrm{A}$ & & & & & & $\mathrm{A}$ & $\mathrm{R}$ & & & & & $\mathrm{A}$ & & \\
\hline 63 & T. marioni & & & & & $\mathrm{R}$ & & & $\mathrm{R}$ & & & & & $\mathrm{R}$ & & & & & & & \\
\hline 64 & T. oblonga & & $\mathrm{A}$ & & & $\mathrm{F}$ & & & & & & & $\mathrm{A}$ & $\mathrm{F}$ & & & & & & & \\
\hline 65 & T. plicata & & $\mathrm{R}$ & & & & & $\mathrm{R}$ & & & & & & $\mathrm{R}$ & & & & & & & \\
\hline 66 & T. rotunda & & $\mathrm{F}$ & & & $\mathrm{F}$ & & & & & & & & & & & & $\mathrm{F}$ & & & \\
\hline 67 & T. terquemiana & & $\mathrm{R}$ & & & & & & & $\mathrm{R}$ & & & & $\mathrm{R}$ & & & & & & & \\
\hline 68 & T. tricarinata & & $\mathrm{F}$ & & & & & & & & & $\mathrm{F}$ & & $\mathrm{F}$ & & & & & & & $\mathrm{F}$ \\
\hline 69 & T. trigonula & & $\mathrm{A}$ & & & & & & $\mathrm{A}$ & & & & & $\mathrm{R}$ & $\mathrm{A}$ & & & & & $\mathrm{R}$ & \\
\hline 70 & T. trihedral & & $\mathrm{A}$ & $\mathrm{C}$ & & $\mathrm{A}$ & & & & $\mathrm{A}$ & & & & $\mathrm{C}$ & & & & & $\mathrm{A}$ & & \\
\hline 71 & $\begin{array}{l}\text { Sigmoihauerina } \\
\text { bradyi }\end{array}$ & & & & & $\mathrm{F}$ & & & & & & & & $\mathrm{F}$ & & & $\mathrm{F}$ & & & & $\mathrm{F}$ \\
\hline 72 & $\begin{array}{l}\begin{array}{l}\text { Rupertianella } \\
\text { rupertiana }\end{array} \\
\end{array}$ & & $\mathrm{R}$ & & & $\mathrm{R}$ & & & & & & & $\mathrm{R}$ & $\mathrm{R}$ & & & & & & & \\
\hline 73 & \begin{tabular}{|l} 
Borelis \\
schlumbergeri
\end{tabular} & & $\mathrm{A}$ & & & $\mathrm{C}$ & & A & & & & & & $\mathrm{C}$ & A & & & & & A & \\
\hline 74 & $\begin{array}{l}\text { Coscinospira } \\
\text { hemprichii }\end{array}$ & A & $\mathrm{R}$ & & & & A & & & & $\mathrm{A}$ & $\mathrm{A}$ & & A & & & & & & & \\
\hline 75 & Peneroplis arietinus & & $\mathrm{C}$ & & & $\mathrm{C}$ & & & $\mathrm{C}$ & & & & & $\mathrm{C}$ & & & & & & & \\
\hline 76 & P. bradyi & $\mathrm{R}$ & $\mathrm{A}$ & & & $\mathrm{R}$ & & & & $\mathrm{A}$ & & & & A & & & & & & & \\
\hline 77 & P. pertusus & & $\mathrm{F}$ & & & $\mathrm{F}$ & & & & & & & & $\mathrm{F}$ & & & & $\mathrm{F}$ & & & \\
\hline 78 & P. planatus & & & & & $\mathrm{A}$ & & & & & $\mathrm{A}$ & $\mathrm{A}$ & & $\mathrm{R}$ & & & $\mathrm{A}$ & & & & $\mathrm{R}$ \\
\hline 79 & Sorites marginalis & & $\mathrm{A}$ & & & $\mathrm{F}$ & & & & & & & & $\mathrm{A}$ & & $\mathrm{F}$ & & & & & \\
\hline 80 & S. orbiculus & & $\mathrm{C}$ & & & $\mathrm{C}$ & & & & & & & $\mathrm{C}$ & $\mathrm{C}$ & & & & & & & \\
\hline 81 & $\begin{array}{l}\text { Amphimorphina } \\
\text { butonensis }\end{array}$ & & $\mathrm{R}$ & & & & & & & & & & & $\mathrm{R}$ & & & $\mathrm{R}$ & & & & \\
\hline 82 & Fissurina sp. & & $\mathrm{F}$ & & & & & & & & $\mathrm{F}$ & & & $\mathrm{F}$ & & & & & & $\mathrm{F}$ & \\
\hline 83 & \begin{tabular}{|l|}
$\begin{array}{l}\text { Bolivina } \\
\text { pseudoplicata }\end{array}$ \\
\end{tabular} & & A & & & A & & & $\mathrm{R}$ & & & & & & A & & & & & & \\
\hline 84 & B. pseudopunctata & & $\mathrm{C}$ & & & & C & & & & & & & $\mathrm{C}$ & & & & & & $\mathrm{C}$ & \\
\hline
\end{tabular}




\begin{tabular}{|c|c|c|c|c|c|c|c|c|c|c|c|c|c|c|c|c|c|c|c|c|}
\hline 85 & B. variabilis & & $\mathrm{F}$ & & & & & $\mathrm{F}$ & & & & & & & & & & & & \\
\hline 86 & Sagrinella lobata & & $\mathrm{R}$ & & & $\mathrm{A}$ & & & $\mathrm{A}$ & & & & A & & $\mathrm{R}$ & & & & $\mathrm{R}$ & \\
\hline 87 & Reussella spinulosa & & & & & $\mathrm{F}$ & & & & & $\mathrm{F}$ & & $\mathrm{F}$ & & & & & & & $\mathrm{F}$ \\
\hline 88 & Eponides repandus & & $\mathrm{C}$ & & & & & $\mathrm{C}$ & & & & & $\mathrm{C}$ & & & & & & & \\
\hline 89 & Rosalina anomala & $\mathrm{A}$ & $\mathrm{R}$ & & & $\mathrm{R}$ & & $\mathrm{A}$ & & & & $\mathrm{R}$ & A & & & & & & & \\
\hline 90 & R. bradyi & & $\mathrm{F}$ & & $\mathrm{A}$ & & $\mathrm{A}$ & & $\mathrm{F}$ & & & & $\mathrm{F}$ & & & & & & & \\
\hline 91 & R. globularis & & & & & $\mathrm{C}$ & & $\mathrm{C}$ & & & & & $\mathrm{C}$ & & & & & $\mathrm{C}$ & & \\
\hline 92 & $R . \mathrm{sp}$ & & $\mathrm{R}$ & & & & & & & & & & $\mathrm{R}$ & & & & & & & \\
\hline 93 & Hyalinea balthica & $\mathrm{F}$ & & & & $\mathrm{F}$ & & & & & & & $\mathrm{F}$ & & & & & & & \\
\hline 94 & $\begin{array}{l}\text { Planorbulina } \\
\text { mediterranensis }\end{array}$ & & & & & & & & $\mathrm{F}$ & & & & $\mathrm{R}$ & & & & & & & \\
\hline 95 & $\begin{array}{l}\text { Cymbaloporella } \\
\text { tabellaeformis }\end{array}$ & & $\mathrm{F}$ & & & $\mathrm{F}$ & & & & & $\mathrm{F}$ & & & & & & & & $\mathrm{F}$ & \\
\hline 96 & $\begin{array}{l}\text { Amphistegina } \\
\text { lessonii }\end{array}$ & & $\mathrm{C}$ & & & $\mathrm{C}$ & & & & & & & $\mathrm{C}$ & & & & & & & \\
\hline 97 & A. lobifera & & $\mathrm{R}$ & & & $\mathrm{R}$ & & & & & $\mathrm{R}$ & & $R$ & & & & & & & \\
\hline 98 & A. radiate & & $\mathrm{F}$ & & & $\mathrm{F}$ & & & & & & & & & & $\mathrm{F}$ & & & & \\
\hline 99 & Nonion fabum & & $\mathrm{C}$ & & & & & $\mathrm{C}$ & & & & & $\mathrm{C}$ & & & & & & & \\
\hline 100 & Neorotalia calcar & & $\mathrm{A}$ & & & & & & $\mathrm{A}$ & & & & $\mathrm{R}$ & & & & & & & \\
\hline 101 & $\begin{array}{l}\text { Pararotalia } \text { cf. } P . \\
\text { ozawai }\end{array}$ & & & $\mathrm{R}$ & & & & & & & & & $\mathrm{R}$ & & & & & & & \\
\hline 102 & Ammonia aoteana & & & A & $\mathrm{R}$ & & & A & & & & & A & & & & & $\mathrm{R}$ & & \\
\hline 103 & A. beccarii & $\mathrm{F}$ & & A & & $\mathrm{F}$ & $\mathrm{C}$ & & & $\mathrm{A}$ & & $\mathrm{C}$ & A & $\mathrm{F}$ & & $\mathrm{F}$ & & & $\mathrm{R}$ & $\mathrm{F}$ \\
\hline 104 & A. convexa & & $\mathrm{R}$ & & & $\mathrm{R}$ & & & & & & & $\mathrm{R}$ & & & & & & & \\
\hline 105 & A. parkinsoniana & & $\mathrm{F}$ & & & $\mathrm{F}$ & & & & & & & $\mathrm{F}$ & & & & & & & \\
\hline 106 & Elphidium aculeatum & & & A & & $\mathrm{A}$ & & & & & & & A & & & & $\mathrm{R}$ & & & \\
\hline 107 & E. advenum & & & & & $\mathrm{F}$ & & & $\mathrm{F}$ & & & & $\mathrm{F}$ & & & & & & & \\
\hline 108 & E. crispum & & $\mathrm{C}$ & & & $\mathrm{C}$ & & & & & & & $\mathrm{C}$ & & & & & & & \\
\hline 109 & E. macellum & & & $\mathrm{C}$ & & $\mathrm{C}$ & & & & & & & & & $\mathrm{C}$ & & & & & \\
\hline 110 & E. margaritaceum & & $\mathrm{R}$ & & & & & $\mathrm{R}$ & & & & & $\mathrm{R}$ & & & & & & & \\
\hline 111 & E. gerthi & & & $\mathrm{F}$ & & $\mathrm{F}$ & & & & & & & & & & $\mathrm{F}$ & & & & \\
\hline
\end{tabular}

A: Abundant: more than 15; C: Common: 10-15; F: Frequent: 5-10; R: Rare: less than 5.

Order: Foraminiferida Eichwald, 1830

Suborder: Textulariina Delage and Herouard, 1896

Superfamily: Spiroplectamminoidae Cushman, 1927

Family: Spiroplectamminidae Cushman, 1927

Subfamily: Spiroplectammininae Cushman, 1927

Genus: Spiroplectinella Kisel'man, 1972

Spiroplectinella sagittula Defrance, 1824

(Figure 2. 1-2)

1824 Textularia sagittula (DEFRANCE): 177.
2009 Spiroplectinella sagittula DEFRANCE; Milker et al.: 215, pl. 1, figs. 7-9.

Material: This species is identified as an abundant form in samples 2, 5, and 9, and as a common in sample 13.

Geographical distribution: Textularia sagittula (DEFRANCE) was recorded in the Gulf of Iskenderun by (Oflaz, 2006) and from western Mediterranean Sea (Milker et al., 2009 and Milker and Schmiedl, 2012).

\section{Spiroplectinella sp.}

(Figure 2. 3-4) 
Description: Wall agglutinated; test triangular to subtriangular; chambers biserially arranged, laterally compressed and rapidly increasing in size as added; sutures depressed and slightly curved; periphery acute; aperture low arch at the base of the apertural face.

Material: It is recorded as frequent in samples 5,13 , and 15 , and as a rare in samples 8 and 12 .

Superfamily: Verneuilinoidea Cushman, 1911

Family: Verneuilinidae Cushman, 1911

Subfamily: Verneuilininae Cushman, 1911

Genus: Gaudryina d'Orbigny, 1839

Gaudryina rudis Wright, 1900

(Figure 2. 5-8)

1900 Gaudryina rudis WRIGHT: 53, pl. 2, fig. 1.

2009 Connemarella rudis (WRIGHT); Milker et al.: 215, pl. 1, fig. 15 .

Material: This species is recorded as an abundant form in samples 2, 5, and as a frequent form in samples 3 and 13.

Geographical distribution: Connemarella rudis Wright, was recorded in Hebridean shelf, west of Scotland (Murray, 2003), New Caledonia, Southwestern Pacific (Debenay, 2012) and from western Mediterranean Sea (Milker et al., 2012).

Superfamily: Textlaroidea Ehrenberg, 1838

Family: Textlaridae Ehrenberg, 1838

Subfamily: Textulariinae Ehrenberg, 1838

Genus: Textularia Defrance, 1824

Textularia agglutinans d'Orbigny, 1839

(Figure 2. 9-11)

1839 Textularia agglutinans D’ORBIGNY: 144, pl. 1, figs. 17-18, 32-34.

2006 Textularia agglutinans D’ORBIGNY; Hussain et al.: 1660, figs. 3-6; 1661, figs. 4-11; 1662, figs. 1-5.
Material: Textularia agglutinans d'Orbigny is identified as an abundant form in samples 2, 9, 13 and 17 , and as a rare form in samples 5, and 8 .

Geographical distribution: This species was recorded from several areas worldwide such as southern Thailand (Jumnongthai, 1980), Spain (Ariza,1988), southern Norway (Alve, 1995), Bermuda islands (Javaux, et al., 2003), the central Adriatic Sea (Sabbatini et al., 2005), Central east coast of India (Rana, 2009), the Dardanelles Strait (Meriç et al., 2009), western Mediterranean Sea (Milker et al., 2012), Indonesia (Suhartati and Muchlisin, 2012), coast of Iligan Bay, Mindanao, Philippines (Lacuna, et al., 2013) and the Egyptian Red Sea (Madkour, 2013).

Textularia candeiana d'Orbigny, 1839

(Figure 2. 12-13)

1839 Textularia candeiana D'ORBIGNY: 143; pl. 1, figs. 25-27.

2009 Textularia candeiana D’ORBIGNY; Parker: 44, figs. 34a-f.

Material: This species is found as an abundant form in samples 9 and 14, and as a common form in samples 2, 3, and 13 .

Remarks: The recorded form differes from type species by its slightly narrow early portion, much compressed and later ones enlarging rapidly, and the final chamber is semi-inflated.

Geographical distribution: This species was identified from several areas such as the North American Atlantic Coast (Culver and Buzas, 1980 and Culver, 1986), the Caribbean Region (Culver and Buzas, 1982), and Western Australia (Parker, 2009).

Textularia conica d'Orbigny, 1839

(Figure 2. 14-16)

1839 Textularia conica D'ORBIGNY: 143, pl. 1, figs. 19-20.

2009 Textularia conica D’ORBIGNY; Sarkar and Gupta: 44, pl. 10, fig 7. 
Material: This species is recorded as frequent in samples 2, 5, and 12, and as a common form in samples 13 and 20.

Geographical distribution: This species was recorded from Bermuda islands (Javaux and Scott, 2003), Eastern Mediterranean (Oflaz, 2006), Northern Adriatic Sea (Sabbatini et al., 2005), and western Mediterranean Sea (Milker et al., 2012).

Textularia gramen d'Orbigny, 1846

(Figure 2. 17-19)

1846 Textularia gramen D’ORBIGNY: 248, table 1, figs. 4-6.

2009 Textularia bocki HOEGLUND; Avsar et al.: 134, pl. 1, figs. 9-10.

Material: In the present study, Textularia gramen d'Orbigny occures in samples 2, 5, and 12 as an abundant form, and as a rare in samples 2, 5, 13 and 14 .

Geographical distribution: This species was recorded from several areas such as the Caribbean Region (Culver and Buzas, 1982), Spain (Ariza, 1988), northern Argentina (Mercau et al., 2011) and western Mediterranean Sea (Milker and schmidl, 2012).

\section{Textularia $\mathrm{sp} .1$}

(Figure 2. 20-22)

Description: Test biserial throughout, subtriangular in side view, ovate in end view; periphery rounded throughout; chambers wider than high, increasing gradually in width slightly inflated; wall coarsely agglutinated; sutures slightly depressed, nearly horizontal; aperture an elongate slit a low broad opening at the base of the inner margin of the final chamber, with a distinct flaplike lip bordering the opening.

Material: This form is recorded as frequent in samples 1, 5, 12 and 18, and as a rare form in samples 7 and 13 .

\section{Textularia $\mathrm{sp} .2$}

(Figure 2. 23-24)

Description: Test characterized by a subtriangular shape in outline; initial end narrowly rounded, rapidly widening toward the apertural end; periphery subacute in the early portion, later thickening; the wall is coarsely agglutinated; chambers are triserially arranged, laterally compressed and rapidly increasing in size as added; sutures indistinct by slightly depressed; nearly horizontal; three apertures distinct with suboval to subcircular shape.

Material: This species id identified from samples 2, and 5 as abundant form, and as a common form in sample 13.

Suborder: Miliolina Delage and Herouard, 1896

Superfamily: Cornuspiroidea Schultze, 1854

Family: Fischerinidae Millett, 1898

Subfamily: Fischerininae Millett, 1898

Genus: Planispirinella Wiesner, 1931

Planispirinella exigua (Brady), 1879

(Figure 2. 25 and Figure 3. 1)

1879 Hauerina exigua BRADY: 27.

2009 Planispirinella exigua (BRADY); Parker: 157, figs. 110a-k.

Material: In the present study, Planispirinella exigua Brady occurs as a common form in samples 3, 5 and 13 .

Geographical distribution: This form was nidentified from the Red Sea (Brady, 1879) and from Ningaloo Reef, Western Australia (Parker, 2009). 


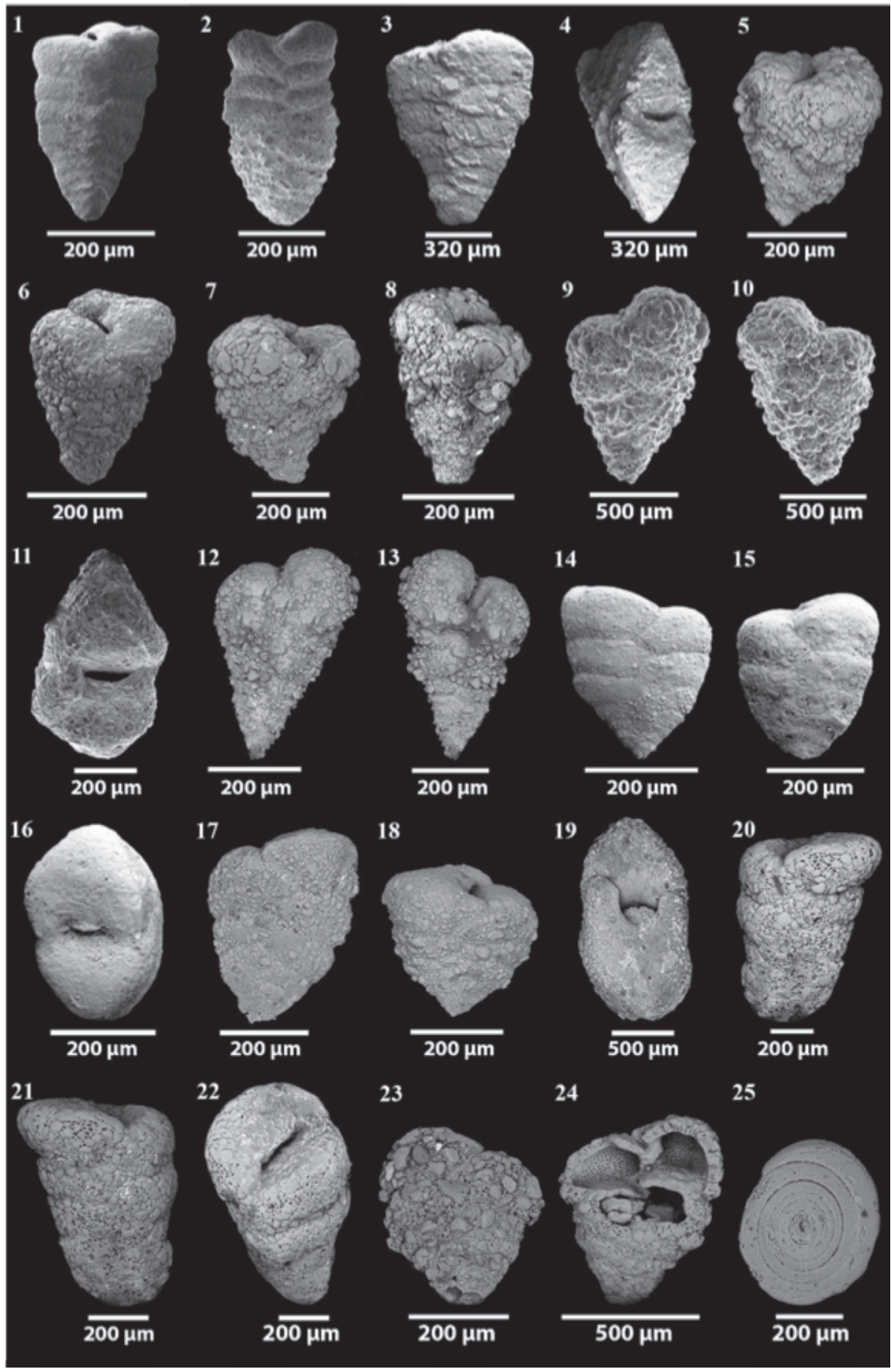

Figure 2. 1-2. Spiroplectinella sagittula Defrance, side views. 3-4; Spiroplectinella sp., lateral view and apertural view. 5-8. Gaudryina rudis Wright, 5, 7. Side views; 6, 8. Lateral views; 9-11. Textularia agglutinans d'Orbigny, 9-10. Side views, 11. Apertural view; 12-13. Textularia candeiana d'Orbigny, side views; 14-16. Textularia conica d'Orbigny, 14-15. Side views, 16. Apertural view; 17-19. Textularia gramen d'Orbigny, 18-19. Side views, 19. Apertural view; 20-22. Textularia sp.1, 20-21. Side views, 22. Apertural view; 23-24. Textularia sp. 2, side views; 25. Planispirinella exigua, Brady, side view. 
Superfamily: Milioloidea Ehrenberg, 1839

Family: Spiroloculinidae Wiesner, 1920

Genus: Adelosina d'Orbigny, 1826

Adelosina laevigata d'Orbigny, 1826

(Figure 3. 2-3)

1826 Adelosina laevigata D’ORBIGNY: 304, fig.1.

1988 Adelosina laevigata D’ORBIGNY; Loeblich and Tappan: 90, pl. 337, figs. 5-12.

Material: In the present study, Adelosina laevigata d'Orbigny occurs as a common form in samples 2, 7, and 8 as a rare form in samples 13 , and 16.

Geographical distribution: Adelosina laevigata d'Orbigny was identified from the Neogene of Mediterranian by d'Orbigny, 1826 and 1846.

\section{Adelosina mediterranensis (Le Calvez and Le} Calvez), 1958

(Figure 3. 4-5)

1958 Quinqueloculina mediterranensis LE CALVEZ and LE CALVEZ: 177, pl. 4, figs. 2931.

1991 Adelosina mediterranensis (LE CALVEZ and LE CALVEZ); Cimerman and Langer: 28, pl. 19, figs. 1-16.

2009 Adelosina mediterranensis (LE CALVEZ and LE CALVEZ); Milker et al.: 215, pl. 1, fig. 16.

Material: In the present study, this species is reported frequently from samples 5, 6, 13 and 20 .

Geographical distribution: Adelosina mediterranensis Le Calvez and Le Calvez was recorded from several regions such as Gulf of Naples, Italy (Sgarrella and Moncharmont Zei, 1993), Kallithea Bay, Greece (Rasmussen, 2005), West Turkey (Avsar et al., 2009), Western Mediterranean Sea (Milker et al., 2009) and Southwestern Pacific (Debenay, 2012).

\section{Adelosina sp.}

(Figure 3. 6-7)

Description: Wall porcelaneous; proloculus followed by an embracing, planispirally enrolled second chamber; periphery angular; aperture rounded on a neck; test surface partly ornamented with costae.

Material: This species is identify from samples 5, 16 and 19 as a common form and as a rare form from samples 8 and 13 .

Genus: Cribrolinoides Cushman and LeRoy, 1939

Cribrolinoides curta Cushman, 1917

(Figure 3. 8-9)

1917 Quinqueloculina disparilis D'ORBIGNY var. curta - CUSHMAN: 49; pl. 14, fig. 2, text-fig. 30 .

1951 Cribrolinoides curta CUSHMN; Asano: 9, pl. 6, figs. 63-64.

2009 Quinqueloculina cf. Q. curta CUSHMAN; Parker: 193, figs. 136a-e.

Material: This species is recorded presently as an abundant form in samples 5 and 9 and as a common form in samples 1 and 2.

Geographical distribution: Cribrolinoides curta Cushman was recorded in the North Pacific Ocean (Cushman, 1917), Tokyo (Asano, 1951), northern Great Barrier Reef, Australia (Baccaert, 1987) and Ningaloo Reef, Western Australia (Parker, 2009).

Genus: Spiroloculina d'Orbigny, 1826

Spiroloculina acutimargo Brady, 1884

(Figure 3. 10-12)

1884 Spiroloculina acutimargo BRADY: 154, pl. 10, figs. 12-15.

1994 Spiroloculina acutimargo BRADY; Jones: 26, pl. 10, fig. 13.

Material: In the present study, this species is distinguished from samples 1, 13 and 14 as an 
abundant form and as a frequent form in Samples 2 and 12 .

Geographical distribution: This species was recorded from several areas worldwide such as Caribbean region (Culver and Buzas, 1982), southeastern Arabian Sea (Sarkar and Gupta, 2009), Green Bay Cave on Bermuda (Scott and Hengstum, 2011) and Southwestern Pacific (Debenay, 2012).

Spiroloculina aequa Cushman, 1932

(Figure 3. 13-15)

1932 Spiroloculina aequa, CUSHMAN: 38, pl.9, figs. 13a-b.

2009 Spiroloculina aequa, CUSHMAN; Devi and Rajashekhar: 23, fig. 1.

Material: In the present study, Spiroloculina aequa Cushman occurs as a common form in samples 2, 5 and 17 and as a rare form in samples 13 and 18.

Geographical distribution: This species was recorded from several Indian coastlines such as Karwar, central west coast by Khare, 1992 and Devi and Rajashekhar, 2009.

Spiroloculina antillarum d'Orbigny, 1839

(Figure 3. 16-17)

1839 Spiroloculina antillarum D'ORBIGNY: 166, pl. 7, figs. 3-4.

2009 Spiroloculina antillarum D'ORBIGNY; Parker: 341, figs. 246a-1; 247a-1.

Material: Spiroloculina antillarum d'Orbigny is recorded here as an abundant form in samples 2,13 , and 14 and as a frequent form in samples 5 and 9.

Geographical distribution: This species was recorded from the Caribbean Region (Culver and Buzas, 1982), the northwestern Mediterranean coast of Egypt (Samir et al., 2003), the Dardanelles Strait, Turkey (Meriç et al., 2009) and from the Egyptian Red Sea (Madkour, 2013).
Spiroloculina communis Cushman and Todd, 1944

(Figure 3. 18-20)

1944 Spiroloculina communis CUSHMAN and TODD: 63, pl. 9, fig. 4-5, 7- 8 .

1990 Spiroloculina communis CUSHMAN and TODD; Kumar et al.: 57,pl. 1, fig. 5, table 1.

Material: In the present study, this species is recorded as frequent in samples 1, 5 and 15 .

Geographical distribution: This cosmopolitan species was recorded from different Arabian Sea areas by (Gandhi et al., 2002; Schumacher et al., 2007 and Sarkar and Gupta 2009) and from Tambelan Islands of Indonesia. (Natsir and Muchlisin, 2012) and coast of Iligan Bay, Mindanao, Philippines (Lacuna, et al., 2013).

Spiroloculina depressa d'Orbigny, 1826

(Figure 3. 21-23)

1826 Spiroloculina depressa D’ORBIGNY: 298.

2009 Spiroloculina depressa D'ORBIGNY; Devi and Rajashekhar: 24, image 2. fig. d.

Material: In the present study, Spiroloculina depressa d.Orbigny is recorded as a common in samples 2, 9, 13 and 20, and as a rare form in samples 5 and 11 .

Geographical distribution: This species was recorded from several areas worldwide such as Florida (Buzas and Severin, 1982), Karwar, central west coast of India (Khare, 1992), France (Debenay et al., 2001), Gulf of Iskenderun, Eastern Mediterranean (Oflaz, 2006), Thailand Gulf (Melis and Violanti, 2006), the Dardanelles Strait, Turkey (Meriç et al., 2009), Indian coast (Devi and Rajashekhar, 2009) and coast of Iligan Bay, Mindanao, Philippines (Lacuna et al., 2013).

Spiroloculina elegans Cushman, 1917

(Figure 3. 24-25; Figure 4. 1)

1917 Spiroloculina elegans CUSHMAN: p. 29. 


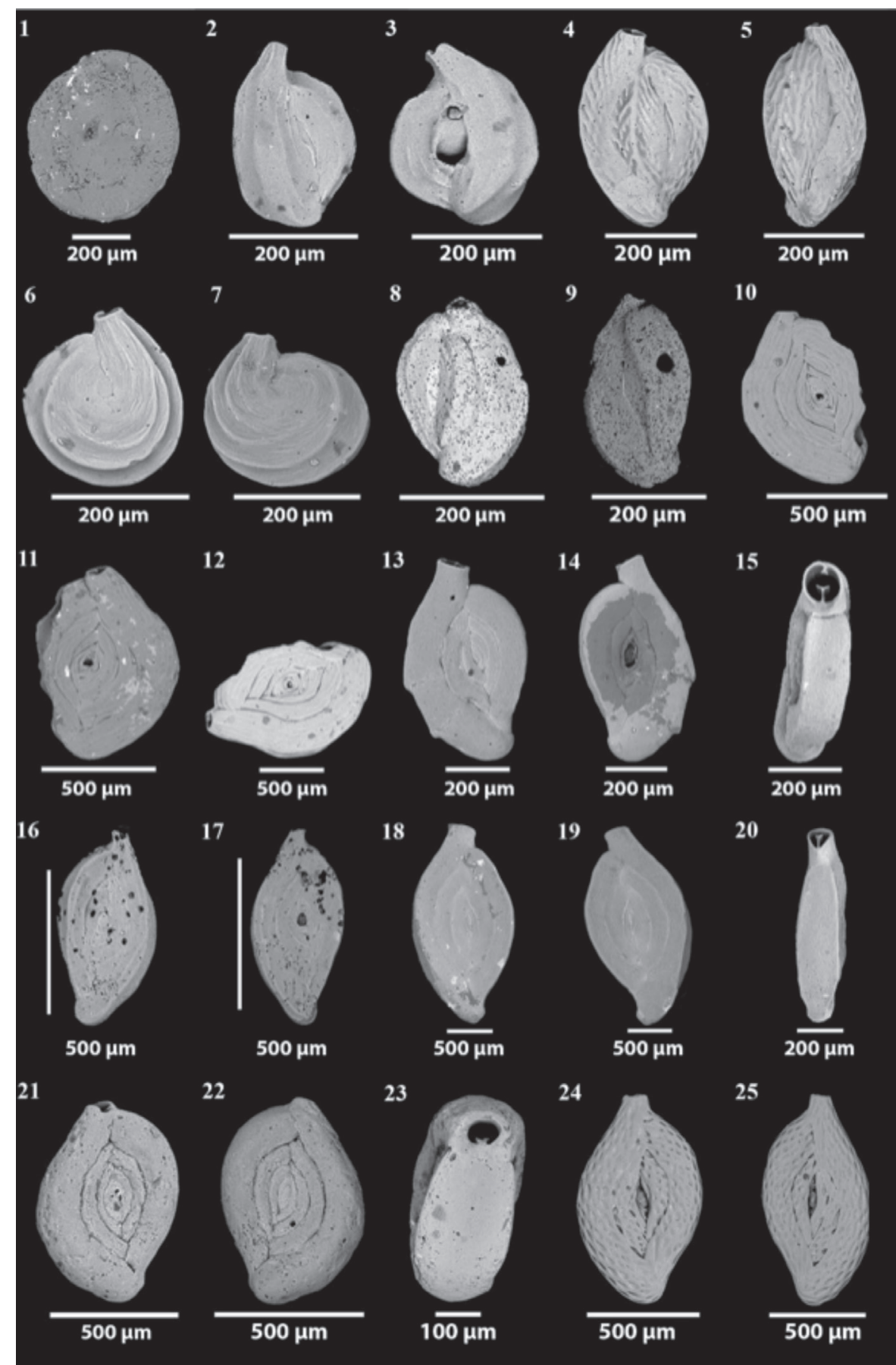

Figure 3. 1. Planispirinella exigua, Brady, side view; 2-3. Adelosina laevigata d'Orbigny, side views; 4-5. Adelosina mediterranensis Le Calvez and Le Calvez, side views; 6-7. Adelosina sp., side views; 8-9. Cribrolinoides curta Cushman, side views; 10-12. Spiroloculina acutimargo Brady, 10-11. Side views, 12. Oblique view; 13-15. Spiroloculina aequa Cushman, 13-14. Side views, 15. Apertural view; 16-17. Spiroloculina antillarum d'Orbigny, side views; 18-20. Spiroloculina communis Cushman and Todd, 18-19. Side views, 20. Apertural view; 21-23. Spiroloculina depressa d.Orbigny, 21-22. Side views, 23. Apertural view; 24-25. Spiroloculina elegans Cushman, side views. 
Material: In the present study, Spiroloculina elegans Cushman, is identified as a frequent form in samples 2, 5, and 9, and as a rare form in Samples 13 and 17.

Geographical distribution: Cushman (1917) recorded this species from the recent sediments of Pacific Ocean.

Spiroloculina tenuiseptata Brady, 1884

(Figure 4. 8-9)

1884 Spiroloculina tenuiseptata BRADY: 153, pl. 10, figs. 5-6.

2005 Spiroloculina tenuiseptata BRADY; Rasmussen: 61, pl. 3, fig. 12.

Material: In the present study, Spiroloculina tenuiseptata Brady is detected as a common form in samples 2, 9 and 13.

Geographical distribution: This species was recorded from several regions such as Gulf of Iskenderun (Oflaz, 2006), Maldives Ridge, southeastern Arabian Sea (Sarkar and Gupta, 2009), Dardanelles Strait in Turkey (Meriç et al., 2009) and Western Mediterranean (Milker and Schmiedl, 2012).

\section{Spiroloculina sp.1}

(Figure 4. 2-4)

Description: Test subcircular, slightly longer than broad in lateral view; with slightly rounded peripheral margins; wall porcelaneous and imperforate; chambers U-shaped in transverse section, with a rounded margin; surface covered with costae that are arranged with an angle to the chamber margin so that they are not continuous from the basal end to the apertural end; aperture rounded at the end of a distinct neck covered with costae.

Material: This species is recognized from samples1, 5, 13, and 18 as a common.

\section{Spiroloculina sp. 2}

(Figure 4. 5-7)
Description: Test fusiform in shape, slightly longer than broad in lateral view and strongly biconcave in end view; wall is porcelaneous; chambers arranged is in "spiroloculine form, leading to a raised some portions; later chambers broad, planispirally arranged, each chamber onehalf coil in length; aperture subcircular at the end of a short cylindrical neck.

Material: In the present study, this form is recorded as frequent in samples 13 and 19, and as a rare form in samples 5 and 10 .

Family: Hauerinidae Schwager, 1876

Subfamily: Siphonapertinae Saidova, 1975

Genus: Siphonaperta Vella, 1957

Siphonaperta agglutinans (d'Orbigny), 1839

(Figure 4. 10-11)

1839 Quinqueloculina agglutinans D'ORBIGNY: 195, pl. 12, figs. 11-13.

1993 Siphonaperta agglutinans

(D'ORBIGNY); Hottinger et al.: 62, pl. 61, figs. 10, 11; pl. 62, figs. 1-3.

2004 Siphonaperta agglutinans (D’ORBIGNY); Meriç et al.: 60, pl. 7, fig. 8.

Material: Siphonaperta agglutinans (d'Orbigny) is recorded here as abundant form in samples 2, 17 and 20, and as a frequently from samples 5 and 8 .

Geographical distribution: This species was recorded from several areas worldwide such as Atlantic Ocean (Cushman, 1929), the Gulf of Aqaba, Red Sea (Hottinger et al., 1993), Aegean Sea (Turkey) (Meriç et al., 2004), the western Mediterranean Sea (Milker and Schmiedl, 2012) and Philippines (Lacuna, et al., 2013).

Siphonaperta horrida (Cushman), 1947

(Figure 4. 12)

1947 Quinqueloculina horrida CUSHMAN: 88, pl. 19, fig. 1. 
1993 Siphonaperta horrida (CUSHMAN); Hottinger et al.: 63, pl. 63, figs. 7-12.

Material: Siphonaperta horrida (Cushman) is identified as an abundant in samples 2, and 9, and as a rare form in samples 5, 15 and 19 .

Geographical distribution: This species was recorded from northwest Gulf of Mexico (Phleger, et al., 1951), northern Gulf of Mexico (Leroy et al., 1974), the Gulf of Aqaba, Red Sea (Hottinger et al., 1993) and Central east coast of India (Rana, 2009).

\section{Siphonaperta irregularis (d'Orbigny), 1826}

(Figure 4. 13-14)

1826 Quinqueloculina irregularis D'ORBIGNY: 302, no. 25.

1958 Quinqueloculina irregularis D’ORBIGNY; Le Calvez and Le Calvez: 166, pl. 3, figs. 1-2.

1991 Siphonaperta irregularis (D'ORBIGNY); Cimerman and Langer: 32, pl. 26, figs. 4-6.

Material: The present species is recorded now as an abundant form in samples 2 and 12, and as a rare form in samples 5 and 13.

Geographical distribution: This species was recorded from France (Debenay et al., 2001), Turkey (Meriç et al., 2009) and Western Mediterranean (Milker and Schmiedl, 2012).

Subfamily: Hauerininae Schwager 1876

Genus: Hauerina d'Orbigny 1839

Hauerina diversa Cushman, 1946

(Figure 4. 15-16)

1946 Hauerina diversa CUSHMAN: 11, pl. 2, figs. 16-19.

1993 Hauerina diversa CUSHMAN; Hottinger et al.: 50, pl. 36, figs. 1-7.
Material: In the present study, Hauerina diversa Cushman is recorded as an abundant form in samples 5 and 13, and as a common form in samples 2, 16 and 20.

Geographical distribution: This species was recorded from several areas such as Atlantic Ocean (Baccaert, 1987), Southern Ryukyu Island Arc, Northwestern Pacific (Hatta and Ujiie, 1992), Gulf of Aqaba and north of Red Sea (Said, 1949 and Hottinger et al., 1993) and Haifa Bay (Yanko, 1995).

Genus: Quinqueloculina d'Orbigny, 1826

Quinqueloculina agglutinata d'Orbigny, 1839

(Figure 4. 17-18)

1839 Ouinqueloculina agglutinata D’ORBIGNY: 195, p1. 12, figs. 11-13.

1987 Ouinqueloculina agglutinata D’ORBIGNY; Rao et al.: 164, p1. 1, figs. 22-24.

Material: In the present study, this form is found as abundant form in samples 2, 5, 9 and 17 and as a rare form in samples 1 and 14 .

Geographical distribution: The present species was described from North Pacific Ocean (Cushman, 1917). Later, it was recorded from the north of the Red Sea (Said, 1949), Denmark (Haman, 1966), the Atlantic continental shelf of the U.S.A. (Murray, 1969), Newfoundland (Sen Gupta, 1971), Biscayne Bay, Florida (Ishman et al., 1997) and East coast of India (Gandhi et al., 2002).

Quinqueloculina bradyana Cushman, 1910

(Figure 4. 19-20)

1910 Quinqueloculina bradyana CUSHMAN: 52; pl. 18, fig. 2 .

1995 Quinqueloculina bradyana CUSHMAN; Yassini and Jones: 83; figs. 14-15.

Material: This form is recorded as a common form in samples 2, 7 and 13. 
Geographical distribution: This species was recorded from Bermuda island in the northwest Atlantic Ocean (Javaux et al., 2003), Maldives Ridge, southeastern Arabian Sea (Sarkar, et al, 2009) and New Caledonia, Southwestern Pacific (Debenay, 2012).

Quinqueloculina carinatastriata (Wiesner), 1923

(Figure 4. 21-23)

1923 Adelosina milletti WIESNER var. carinatastriata Wiesner: 76; pl. 14, figs. 190-191.

1988 Quinqueloculina carinatastriata (WIESNER); Haig: 233, pl. 5, figs. 6-10.

2009 Quinqueloculina carinatastriata (WIESNER); Parker: 188, figs. 133a-h, 134a-h.

Material: In the present study, this species is identified as an abundant in samples 2, 5, 8, and 12 , and as a rare form in samples 9 and 13.

Geographical distribution: This species was recorded off Palk Strait, India (Gandhi et al., 2002), Southwestern Pacific (Debenay, 2012) and from the coastal plains of the Aegean Sea (Greece) (Koukousioura et al., 2012).

Quinqueloculina corrugate (Collins), 1958

(Figure 4. 24-25)

1958 Massilina corrugata COLLINS: 362; pl. 2, figs. 11, 12.

1988 Quinqueloculina corrugata(COLLINS), Haig: 233, pl. 5, figs. 15-17.

Material: The present species occurs as an abundant form in samples 5, 13 and 17 and as a common form in samples 2 and 6.

Geographical distribution: This species was identified from the recent sediments of Great Barriers by Collins, 1958 and then by Haig, 1988 from the Papuan Lagoon.

Quinqueloculina debenayi Langer, 1992

(Figure 5. 1)
1992 Quinqueloculina debenayi LANGER: 90, pl. 2, figs. 7-8.

Material: In the present study, this species recorded as abundant form in samples 5 and 13, and as a frequent form in samples 2, 7, and 18 .

Geographicalal distribution: Quinqueloculina debenayi Langer, 1992 identified this species from the lagoon recent sediments at Madang, Papua New Guinea.

Quinquelocnlina granulocostata Germeraad, 1946

(Figure 5. 2-3)

1946 Quinquelocnlina granulocostata, GERMERAAD: 63, pl. 7, figs. 11, pl. 8, fig. 11.

2009 Quinqueloculina granulocostata GERMERAAD; Parker: 211, figs. 150a-k; 151a-h.

Material: In the present study, this species is recorded as an abundant in samples3, 7, 12 and 20 and as a common form in samples 5, 8 and 13 .

Geographical distribution: The present species was described from Indonesia (Germeraad, 1946), the southeast Australian coast (Yassini and Jones, 1995), east coast of India (Gandhi et al., 2002) and Tambelan Archipelago, Indonesia (Suhartati and Muchlisin, 2012).

Quinquelocnlina jugosa Cushman, 1944

(Figure 5. 4-5)

1944 Quinqueloculina seminulum LINNÉ var. jugosa Cushman: 13, pl. 2, fig. 5.

2005 Quinqueloculina jugosa CUSHMAN; Debenay et al.: 332, pl. 1, fig. 16.

Material: In the present study, this form is distinguished as abundant form in samples 2, 5 and 13 and as a common form in samples 9 and 14. 


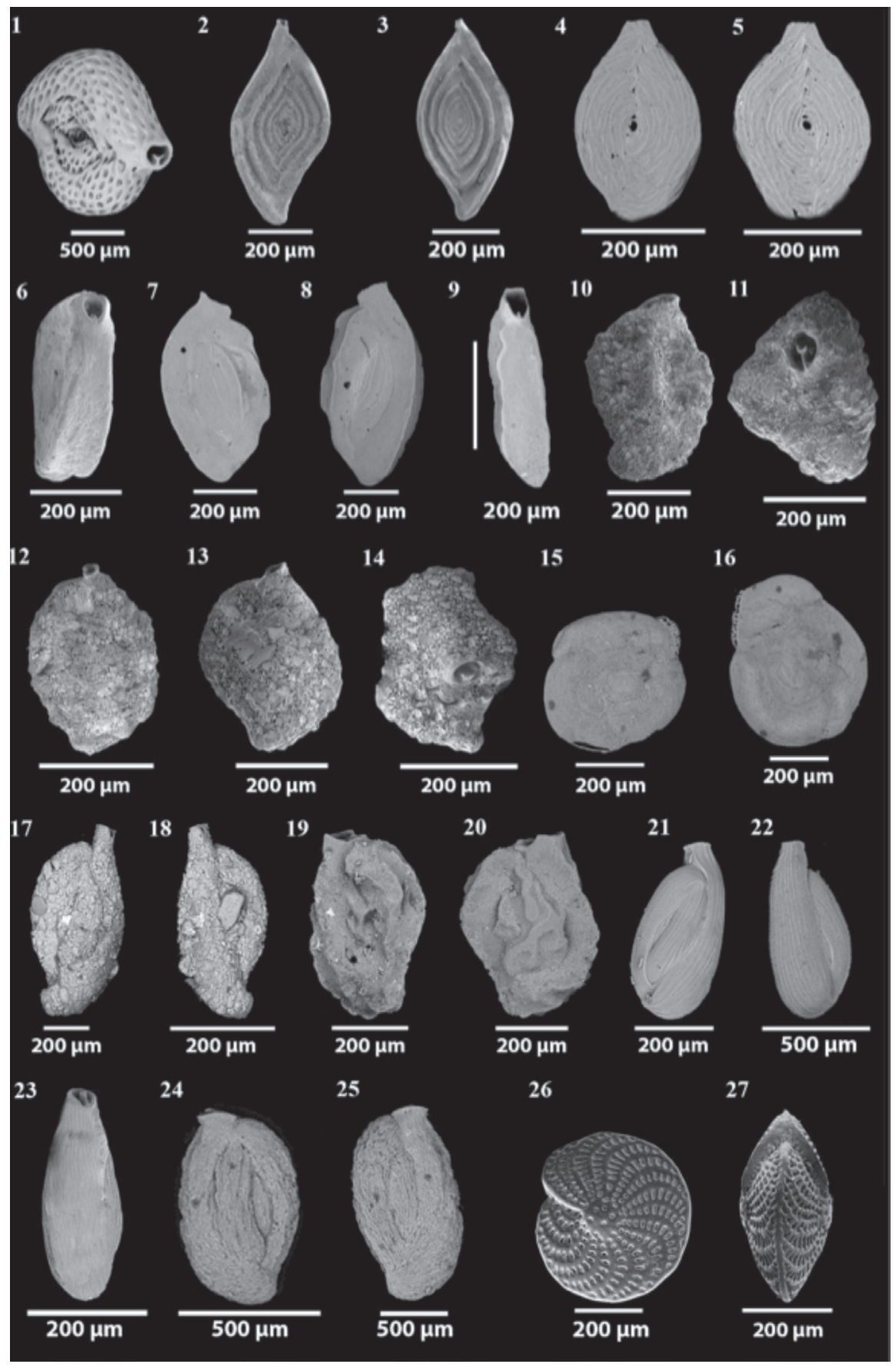

Figure 4. 1- Spiroloculina elegans Cushman, 1. Apertural view; 2. Side view; 3-4. Spiroloculina sp.1, 3. Side view; 4. Apertural view; 5-7. Spiroloculina sp.2, 5-6. Side views, 7. Apertural view; 8-9. Spiroloculina tenuiseptata Brady, Side views; 10-11. Siphonaperta agglutinans d'Orbigny, 10. Side view, 11. Apertural view; 12. Siphonaperta horrida Cushman, side view; 13-14. Siphonaperta irregularis d'Orbigny, 13. Side view, 14. Apertural view; 15-16. Hauerina diversa Cushman, side views; 17-18. Quinqueloculina agglutinata D'orbiony side views; 19-20. Quinqueloculina bradyana, Cushman, side views; 21-23. Quinqueloculina carinatastriata Wiesner, 21-22. Side views, 23. Apertural view; 24-25. Quinqueloculina corrugata Collins, side views; 26-27. Elphidium crispum (Linné), 26. Side view, 27. Apertural view. 
Geographical distribution: Cushman (1944) described this species from the recent deposits of the New England coast. It was later recorded from northern Carolina (Miller, 1953), the Dardanelles Strait in Turkey (Meriç et al., 2009) and Southwestern Pacific (Debenay, 2012).

Quinquelocnlina lamarckiana d'Orbigny, 1839

(Figure 5. 6-7)

1839 Quinquelocnlina lamarckiana D’ORBIGNY: 189, pl. 11, figs. 14-15.

1990 Quinquelocnlina lamarckiana D'ORBIGNY; Kaladhar et al.: 72, table 1.

Material: In the present study, this species is identified as abundant in samples 2, 7 and 10, and as a rare form in samples 5 and 13.

Geographicalal distribution: This cosmopolitan species was described from the recent deposits of Jamaica (d'Orbigny, 1839). It was later recorded from different areas such as California (Bandy, 1953), Carolina (Miller, 1953), India (Bhatia, 1956 and Gandhi et al., 2002), the Atlantic continental shelf of U.S.A. (Murray, 1969), western North America (Lankford and Phleger, 1973), Bermuda islands in the northwest Atlantic Ocean (Javaux et al., 2003), the Dardanelles Strait (Meriç et al., 2009) and Maldives Ridge, southeastern Arabian Sea (Sarkar and Gupta, 2009).

\section{Quinqueloculina lata Terquem, 1876}

(Figure 5. 8-9)

1876 Quinqueloculina lata TERQUEM: 82, pl. 11, figs. 8a-c.

\section{Quinqueloculina lata TERQUEM;} Murray: 17, fig. 4: 9-10

Material: In the present study, it is recorded as a common form in samples 2, 9, 13 and 20 .

Geographical distribution: This species was recorded from several areas worldwide such as France (Terquem 1876 and Levy et al., 1975), the Atlantic continental shelf of U.S.A (Murray, 1969), the English Channel (Murray, 1970), Indian coast (Devi and Rajashekhar, 2009) and western Mediterranean Sea (Milker and Schmiedl, 2012).

Quinqueloculina multimarginata Said, 1949

(Figure 5. 10-11)

1949 Quinqueloculina multimarginata SAID: 10, pI. 1, fig. 34 .

Material:In the presentstudy, Quinqueloculina multimarginata Said occurs as an abundant form in samples 2, 5, 10 and 17 and as a frequent form in samples 8 and 13 .

Geographical distribution: It was described from the recent deposits of northern Red Sea (Said, 1949).

\section{Quinqueloculina neapolitana Sgarrella and Moncharmont Zei, 1993}

(Figure 5. 12-14)

1993 Quinqueloculina neapolitana SGARRELLA AND MONCHARMONT ZEI: 173, pl. 5, figs. 10-12

Material: In the present study, it is recorded as a frequent form in samples 2 and 5, and as a rare form in samples 10 and 13 .

Geographical distribution: Sgarrella and Moncharmont Zei (1993) identified Thid species from thr Gulf of Naples (Italy).

Quinqueloculina padana Perconig, 1954

(Figure 5. 15-17)

1954 Quinqueloculina padana PERCONIG: 95, 97, figs. 1-4.

2009 Quinqueloculina padana PERCONIG; Frezza and Carboni: 55, pl. 1, fig. 9.

Material: In the present study, this species recorded as a common in samples 7, 9, 13 and 18, and as a rare form in samples 2 and 5.

Geographical distribution: Quinqueloculina padana Perconig was recorded from the Aegean 
Sea (Greece) (Koukousioura et al., 2012) and western Mediterranean Sea (Milker et al., 2012).

Quinqueloculina parkeri Brady, 1881

(Figure 5. 18-19)

1881 Miliolina parkeri BRADY: 177; pl. 7, figs. $14 \mathrm{a}-\mathrm{c}$.

2009 Quinqueloculina parkeri Brady; Parker: 233, figs. 167a-g; 168a- j.

Material: In the present study, Quinqueloculina parkeri Brady occurs as an abundant form in samples 3, 11 and 20, and as a frequent form in samples 2, 5, 13 and 17.

Geographical distribution: This species was recorded from several areas such as Hawaii Islands (Brady, 1881), northern Red Sea (Said, 1950), Solomon Islands (Hughes, 1977), East coast of India (Gandhi et al., 2002), southeastern Arabian Sea (Sarkar and Gupta, 2009) and Southwestern Pacific (Debenay, 2012).

Quinqueloculina plicosa Costa, 1856

(Figure 5. 20-22)

1856 Quinqueloculina plicosa COSTA: 322, pI. 25, fig. 2, 5, 7 .

2000 Quinqueloculina plicosa COSTA; AlHitmi: 168, fig.2.

Material: In the present study, this species recorded as an abundant in samples 2, 9 and 13 and as a rare form in samples 5 and 11.

Geographical distribution: It was recorded from Nepal by Costa, 1856 and from the coastline of Qatar Penensula by Al-Hitmi (2000).

Quinqueloculina poeyana d'Orbigny, 1839

(Figure 5. 23-25)

1839 Quinqueloculina poeyana D'ORBIGNY: 191, pl. 11, figs. 25-27.

2010 Quinqueloculina poeyana D'ORBIGNY; Issa: 6, pl. 1, fig. 5.
Material: The present species recorded as abundant in samples 5 and 11 and as a rare form in samples 2, 8 and 13 .

Geographical distribution: Quinqueloculina poeyana D'ORBIGNY was recorded from the recent deposits of Cuba (d'Orbigny, 1839), North Carolina (Miller, 1953), California (Bandy, 1961), the Atlantic continental shell of U.S.A. (Murray, 1969). Later it is recorded from Bahama West of Andros Island (Todd and low, 1971), Florida (Buzas and Severin, 1982), Bermuda islands (Javaux et al, 2003), coast of Iligan Bay, Mindanao, Philippines (Lacuna, et al., 2013) and from Yemen (El-Nakhal, 1980).

\section{Quinqueloculina pseudoreticulata Parr, 1941}

(Figure 6. 2-4)

1941 Quinqueloculina pseudoreticulata PARR: 177, p1. 9, figs. 2-3.

2009 Quinqueloculina pseudoreticulata PARR; Parker: 243, figs. 174a-j; 175a-h.

Material: In the present study, it is found as an abundant form in samples 2, 7 and 15, and as a rare form in samples 5 and 13 .

Geographical distribution: Parr, 1994 described Quinqueloculina pseudoreticulata from the Australian coastlines, then it was described as cosmopolitan species by different authors such as Rocha and Ubaldo, 1964 from Australia; Bahafzallah, 1979 from Saudi Red Sea coastline; Bhalla and Nigam, 1979 and Ragothaman and Kumar, 1985 from Indian coastlines; and Parker, 2009 from Ningaloo Reef, Western Australia.

Quinqueloculina cf. Q. rugosa d'Orbigny, 1826

(Figure 6. 5-7)

1826 Quinqueloculina rugosa D'ORBIGNY: 302; no. 24.

1988 Quinqueloculina cf. Q. rugosa D’ORBIGNY; Haig: 234, pl. 8, figs. 1- 5. 


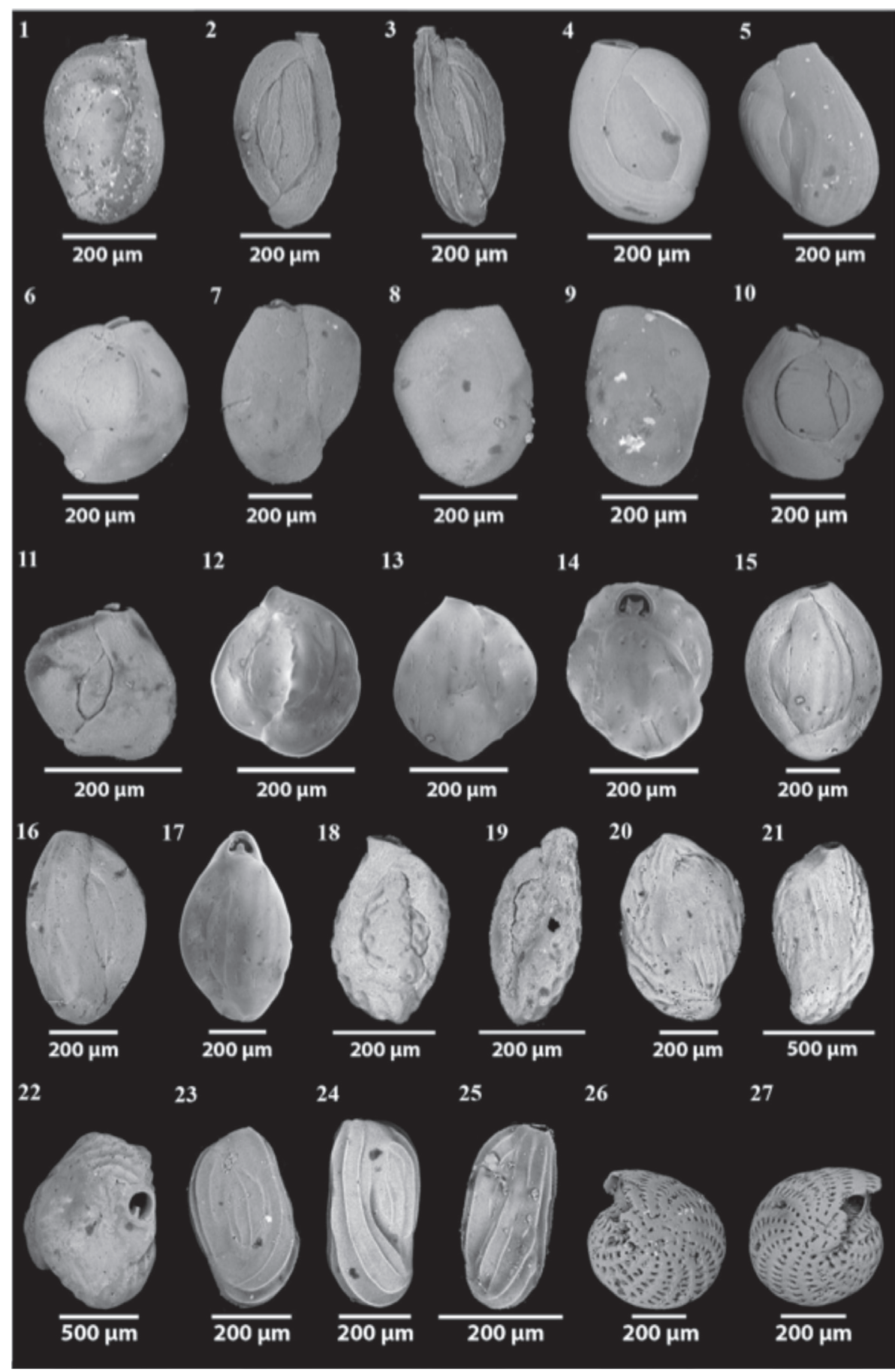

Figure 5. 1- Quinqueloculina debenayi Langer, side view; 2-3. Quinquelocnlina granulocostata Germeraad, side views; 4-5. Quinquelocnlina jugosa Cushman, side views; 6-7. Quinquelocnlina lamarckiana d'Orbigny, side wiews; 8-9. Quinqueloculina lata Terquem, side views; 10-11. Quinqueloculina multimarginata Said, side views; 12-14. Quinqueloculina neapolitana Sgarrella and Moncharmont Zei, 12-13. Side views; 14. Apertural view; 15-17. Quinqueloculina padana Perconig, 15-16. Side views; 17. Apertural view; 18-19. Quinqueloculina parkeri Brady, side views; 20-22. Quinqueloculina plicosa Costa, 20-21. Side views; 22. Apertural view; 23-25. Quinqueloculina poeyana d'Orbigny, 23. Side view, 24-25. Oblique views; 26-27. Elphidium advenum Cushman, side views. 
Material: In the presentstudy, Quinqueloculina cf. Q. rugosa occurs as an abundant form in samples 2 and 5 , and as a frequent form in samples 13 and 18.

Geographical distribution: This species was recorded from the North Pacific Ocean (Cushman, 1917) and Papuan Lagoon (Haig, 1988).

Quinqueloculina seminulum (Linné), 1758

(Figure 6. 8-10)

1758 Serpula seminula LINNÉ: 786. fig. 1 a-c.

2009 Quinqueloculina seminula (LINNAEUS); Parker: 251, figs. 180a-1; 181a-j; 182a-f.

Material: In the present study, this species recorded as an abundant in samples 2, 5, 9 and 18 , and as a common form in samples $6,10,13$ and 20 .

Geographical distribution: This cosmopolitan species was originally described from the recent deposits of the Adriatic Sea (Linné 1758), it was later recorded from numerous localities such as Carolina (Miller, 1953), India (Bhatia, 1956, and Rao and Rao, 1974), Denmark (Haman, 1966), The Atlantic continental shelf of U.S.A. (Murray, 1969), Newfoundland (Sen Gupta, 1971), Solomon islands, Pacific Ocean (Hughes, 1977), France (Debenay et al., 2001), Hebridean shelf, west of Scotland (Murray, 2003), Eastern Mediterranean (Oflaz, 2006) and Southwestern Pacific (Debenay, 2012).

Quinqueloculina subpolygona Parr, 1945

(Figure 6. 20-22)

1945 Quinqueloculina subpolygona PARR: 196: 12, figs. 2a-c.

2009 Quinqueloculina subpolygona PARR; Parker: 262, figs. 191a-j; 192a-1.

Material: In the presentstudy, Quinqueloculina subpolygona occurs as an abundant form in samples 1, 2, 7 and 18, and as a frequent form in samples 5, 10 and 13 .

Geographical distribution: This species was recorded from New Zealand (Hayward et al., 1999) and Southwestern Pacific (Debenay, 2012).

Quinqueloculina cf. Q. triangularis d Orbigny, 1846

(Figure 6. 23-26)

1846 Quinqueloculina cf. Q. triangularis D ORBIGNY: 312.

2005 Quinqueloculina cf. Quinqueloculina triangularis D’ORBIGNY; Toefy et al.: 5, fig. 2F.

Material: In the present study, this species recorded as a common in samples 8, 13 and 20, and as a rare form in samples 2 and 5 .

Quinquelocnlina trigonula Terquem, 1876

(Figure 6. 27-28)

I 876 Quinquelocnlina trigonula TERQUEM: 84, pI. 12, fig. 4.

1975 Quinquelocnlina trigonula TERQUEM; Levy et al.: 172. pl, figs. 10-15.

Material:In the presentstudy, Quinquelocnlina trigonula Terquem occurs as an abundant form in samples 2, 5, 13 and 16, and as a frequent form in samples 9 and 13.

Geographical distribution: This species was described from the northern shores of France (Terquem, 1876 and Levy et al., 1975).

Quinqueloculina undulosecostata Terquem, 1882

(Figure 7. 2-3)

1882 Quinqueloculina undulosecostata TERQUEM: 185, pl. 20. figs. 18-19.

1956 Quinqueloculina undulosecostata TERQUEM; Bhatia: 17, pl. 2, fig. 8.

Material: In the present study, this species recorded as an abundant in samples 1,8 and 12 and as a rare form in samples 5, 8, 13 and 20. 
Geographical distribution: Quinqueloculina undulosecostata Terquem was originally described from the Eocene of Paris (Terquem, 1882). It was later recorded from the recent deposits of the western shores of India (Bhatia, 1956).

Quinquelocnlina vulgaris d'Orbigny, 1826

(Figure 6. 29; Figure 7. 1)

1826 Quinquelocnlina vulgaris D’ORBIGNY, 302, fig. 33.

1980 Quinquelocnlina vulgaris D'ORBIGNY; Steinker: 136, pl. 6, fig. 4.

Material: The presentspecies is recorded as an abundant form in samples 2, 5 and 18, and as a rare form in samples 7,13 and 15 .

Geographical distribution: This species was recorded from several regions such as the central west coast of India (Khare, 1992), Bermuda islands in the northwest Atlantic Ocean (Javaux et al., 2003) and Indian coast (Devi and Rajashekhar, 2009).

\section{Quinqueloculina sp.1}

(Figure 6. 11-13)

Description: Test quinqueloculine, subrectangular in lateral view; periphery and sides broadly rectangular to sub acute; chambers acutely angled, quadrangular in cross section; wall ornamented with numerous, slightly elliptical shallow pits evenly distributed over the surface of the test; sutures slightly depressed; aperture terminal, quadrangular, produced on short a neck, provided with long simple tooth.

Material: In the present study, this species recorded as an abundant form in samples 2, 5 and 17, and as a frequent in samples 9, 13, 14 and 19.

\section{Quinqueloculina sp.2}

(Figure 6. 17-19)

Description: Test elongate about two and a half longer than broad, somewhat triangular in end view, with five chambers visible in the adult; chambers narrow with bicarinate margin; the two carinae merge towards the apertural end, giving a single high carina; oral end truncated and slightly produced, aboral end rounded and produced; sutures slightly depressed; wall finely striate, roughly finished; aperture terminal with a tall oval shape, with thickened peristomal lip; long thin tooth thickened at the tip.

Material: In the present study, it is recorded as an abundant form in samples 2 and 5 and as a rare form in samples 13 and 17.

Subfamily: Miliolinellinae Vella, 1957

Genus: Miliolinella Wiesner, 1931

Miliolinella subrotunda (Montagu), 1803

(Figure 7. 4-5)

1803 Vermiculum subrotundum MONTAGU: 521.

1929 Quinqueloculina subrotunda (MONTAGU); Cushman: 25, pl. 2, fig. 4.

2009 Miliolinella subrotunda (MONTAGU); Parker: 124, figs. 88a-j; 89a- g.

Material: In the present study, Miliolinella subrotunda (Montagu) occurs as an abundant form in samples 2 and 7 and as a rare form in samples 5, 9 and 13 .

Geographical distribution: This species was recorded in Bahama West of Andros Island (Todd and low, 1971), France (Debenay et al., 2001), Bermuda islands (Javaux, et al., 2003), the Gulf of Iskenderun (Oflaz, 2006), Indian coast (Devi and Rajashekhar, 2009), Maldives Ridge, southeastern Arabian Sea (Sarkar and Gupta, 2009), Southwestern Pacific (Debenay, 2012), western Mediterranean Sea (Milker Schmiedl, 2012) and the Egyptian Red Sea coast (Madkour, 2013).

\section{Miliolinella sp.}

(Figure 7.6-7) 


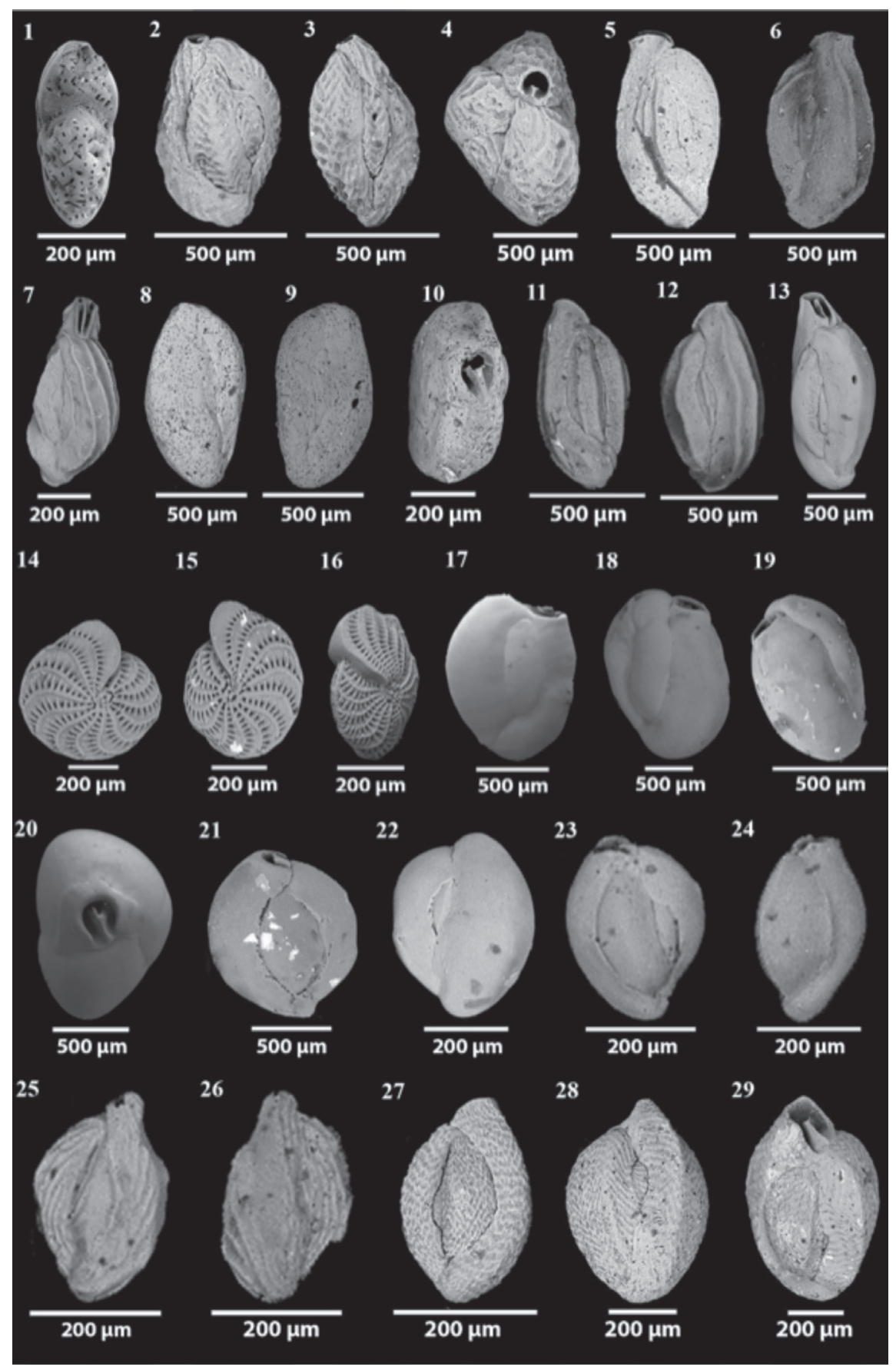

Figure 6. 1- Elphidium advenum Cushman, apertural view; 2-4. Quinqueloculina pseudoreticulata Parr, 2-3. Side views, 4. Apertural view; 5-7. Quinqueloculina cf. Q. rugosa d'Orbigny, 5-6. Side views; 7. Apertural view; 8-10. Quinqueloculina seminulum Linné, 8-9. Side views; 10. Apertural view; 11-13. Quinqueloculina sp.1, 11-12. Side views, 13. Apertural view; 14-16. Elphidium macellum Fichtel and Moll, 14-15. Side views; 16. Apertural view; 17-19. Quinqueloculina sp.2, 17-18. Side views, 19. Apertural view; 20-22. Quinqueloculina subpolygona Parr, 20-21. Side views; 22. Apertural view; 23-26. Quinqueloculina $\mathrm{cf}$. Q. triangularis (d Orbigny), 23. Side view, 2425. Oblique view, 26. Apertural view; 27-28. Quinquelocnlina trigonula Terquem, side views; 29. Quinquelocnlina vulgaris d'Ortitigny, side view. 
Description: Test elliptical to circular in lateral view, flattened; early stage quinqueloculine, latter planispiral with two to three chambers per whorl, slowly increasing in width; wall smooth; aperture terminal, rectangular, compressed, at end of the last chamber.

Material: In the present study, this species recorded as frequent in samples 2, 5, 10 and 13.

Genus: Pseudomassilina Lacroix, 1938

Pseudomassilina pacificiensis Cushman, 1924

(Figure 7. 8-10)

1924 Pseudomassilina pacificiensis CUSHMAN: 66, pl. 24, figs. 1-2.

1993 Pseudomassilina pacificiensis CUSHMAN; Hottinger et al.: 54, pl. 42, figs. 1-4.

Material: In the present study, this species recorded as a rare form in samples 2, 7, 12 and 13.

Geographical distribution: This species was recorded from the Gulf of Aqaba, Red Sea (Hottinger et al., 1993) and and from New Caledonia, Southwestern Pacific (Debenay, 2012).

Genus: Pyrgo (Defrance), 1824

Pyrgo oblonga (d'Orbigny), 1839

(Figure 7. 11)

1839 Biloculina oblonga D’ORBIGNY: 163, pl. 8, figs. 21-23.

\section{Pyrgo oblonga (D’ORBIGNY);} Hottinger et al.: 57, pl. 50, figs. 1-6.

Material: In the present study, Pyrgo oblonga (d'Orbigny) occurs as a rare form in samples 2, 5, 13 and 20.

Geographical distribution: This species was recorded from several areas worldwide such as the central Adriatic Sea (Morigi et al., 2005), Western Mediterranean shelf (Milker, 2010) and Southwestern Pacific (Debenay, 2012).

\section{Pyrgo sp.}

(Figure 7. 12-13)

Description: Test ovate in outline, slightly produced towards the aperture, inflated and subcircular in cross section; periphery obtusely angled to subrounded; wall smooth; chambers highly inflated and rotund with longitudinal two grooves elongates from base of test to the end of the last chamber, aperture subcircular provided with T-shaped tooth with a thin base.

Material: In the present study, this species recorded as frequent in samples 2, 5, 13 and 17.

Genus: Triloculina d'Orbigny, 1826

Triloculina affinis d'Orbigny, 1826

(Figure 7. 14)

1826 Triloculina affinis D'ORBIGNY: 299, pl. 2, figs. 9-10.

1993 Triloculina affinis D'ORBIGNY; Hottinger et al.: 64, pl. 65, figs. 7-10; pl. 66, figs. $1-3$.

Material: In the present study, Triloculina affinis d'Orbigny occurs as a rare form in samples $5,7,13$ and 19 .

Geographical distribution: This species was originally described from the Tertiary of France d'Orbigny (1826). It was later recorded from the recant deposits of Solomon Islands (Hughes, 1977), Southwestern Pacific (Debenay, 2012) and Red Sea (Madkour, 2013).

Triloculina brongniatiana D’Orbigny, 1826

(Figure 7. 15-17)

1826 Triloculina Brongniatiana D'ORBIGNY: 300.

1973 Triloculina Brongniatiana D’ORBIGNY; Brooks: 406, pl. 6, figs. 3-4.

Material: In the present study, it is recorded as an abundant form in samples 2, 9 and 18, and as a frequent form in samples 5 and 13. 
Geographical distribution: D’Orbigny (1826) described Triloculina. Brongniartiana from the recent deposits of Italy. It was recorded later from the southern coast of Puerto Rico (Brooks, 1973).

Triloculina elongotricarinata Debenay, 2013

(Figure 7. 18-19)

2013 Triloculina elongotricarinata DEBENAY: 136, 352, 379.

Material: In the present study, Triloculina elongotricarinata Debenay occurs as an abundant form in samples 2 and 13, and as a rare form in samples 5 and 16.

Geographical Distribution: This species was identified by Debenay, 2013 from the Southwestern Pacific New Caledonia, records this species.

Triloculina fichteliana d'Orbigny, 1839

(Figure 7. 20-21)

1839 Triloculina fichteliana D’ORBIGNY, 171, pl. 9, figs. 8-10.

1993 Triloculina fichteliana D'ORBIGNY; Hottinger et al.: 65, pl. 66, figs. 10-15.

Material: This species is recorded here as a common in samples 2, 4, 5 and 13.

Geographical distribution: This species was recorded from Eastern Pacific (Graham and Militante 1959), Western shore of Andros Island (Todd and low, 1971), Red Sea (Hottinger et al., 1993), southwestern coasts of Turkey (Meriç et al., 2009) and Southwestern Pacific (Debenay, 2012).

Triloculina insignis Brady 1884

(Figure 7. 22-23)

1884 Triloculina insignis BRADY: 165, p1.4, figs. 8-10.

1988 Triloculina insignis BRADY; Shareef and Venkatachalapathy: 434, p1. 2, figs. 7a-b.

Material: Triloculina insignis Brady is recorded as an abundant form in samples 2, 6, 12, and 18 , and as a rare form in samples 5 and 13 .
Geographical distribution: This species was identified from several regions areas in India (Khare, 1992 and Rana, 2009) and from New Zealand (Cameron, 1995).

Triloculina marioni Schlumberger, 1893

(Figure 7. 24)

1893 TriloculinamarioniSCHLUMBERGER: 204, pl. 1, figs. 38-41.

2004TriloculinamarioniSCHLUMBERGER; Meriç et al.: 101, pl. 15, figs. 3-5.

Material: In the present study, this species recorded as a rare in samples 5, 8 and 13 .

Geographical distribution: This species was recorded from several areas worldwide such as eastern Mediterranean, (Oflaz, 2006), the Dardanelles Strait in Turkey (Meriç et al., 2009) and western Mediterranean Sea (Milker and Schmiedl, 2012).

Triloculina oblonga (Montagu), 1803

(Figure 7. 25; Figure 8. 1-2)

1803 Vermiculum oblongum (MONTAGU): 522, pl. 14, fig. 9.

1839 Triloculina oblonga (Montagu); d'Orbigny, p. 175, pi. 10, figs. 3-5.

2009 Triloculina oblonga MONTAGU; Avsar et al.: 134, pl. 1, fig. 24.

Material: In the present study, Triloculina oblonga (Montagu) occurs as an abundant form in samples 2 and 12, and as a frequent form in samples 5 and 13 .

Geographical distribution: This species was described from the recent deposits of Devonshire, England (Montagu, 1803). It was later recorded from Bahama West of Andros Island (Todd and low, 1971), Mukha area, Red Sea (El-Nakhal, 1984), Karwar, central west coast of India (Khare,1992), Bermuda islands (Javaux et al., 2003), Eastern Mediterranean (Oflaz, 2006) and Turkey (Meriç et al., 2009). 


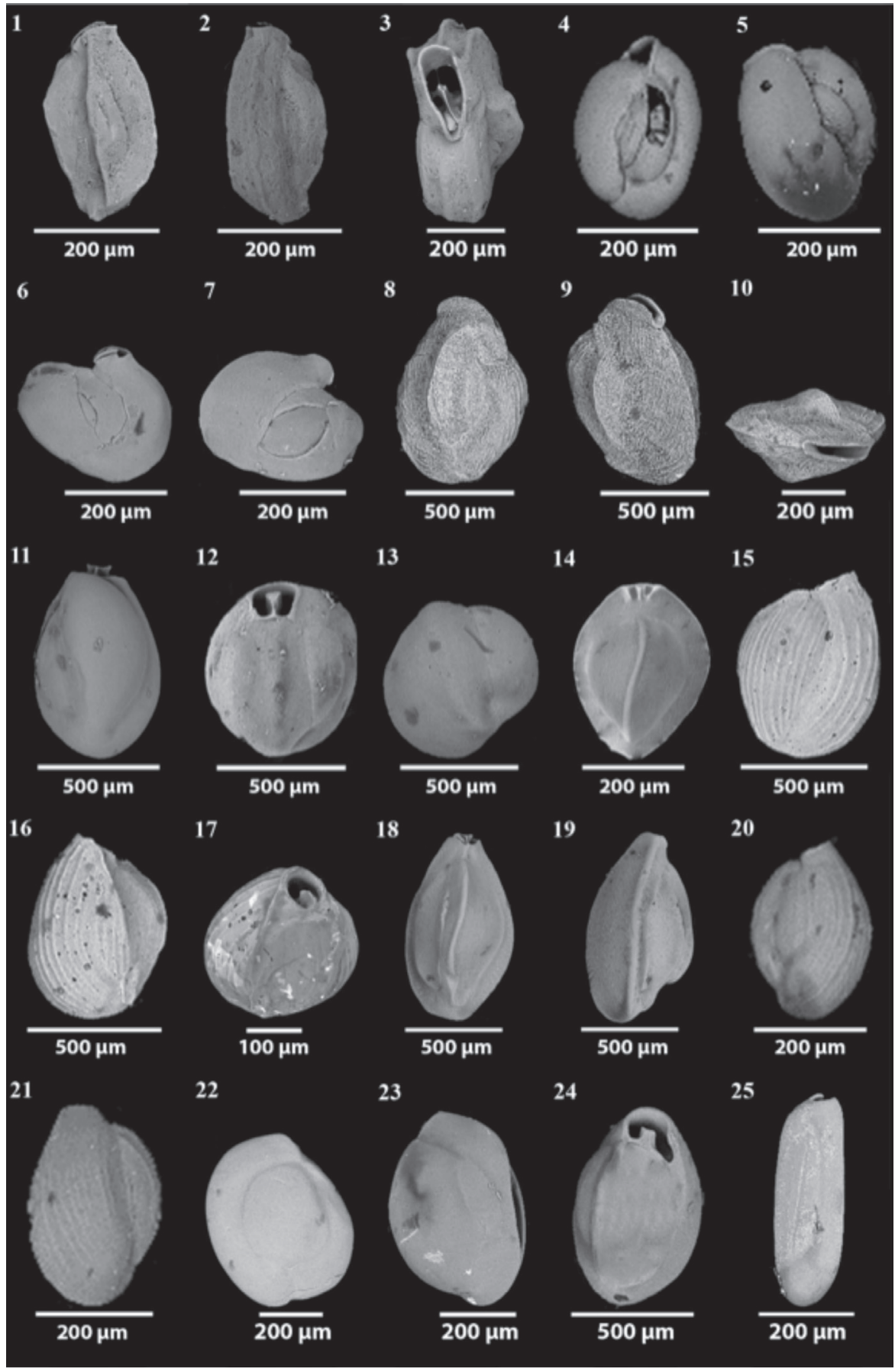

Figure 7. 1- Quinquelocnlina vulgaris d'Ortitign, side view; 2-3. Quinqueloculina undulosecostata Terquem, side views; 4-5. Miliolinella subrotunda Montagu, side views; 6-7. Miliolinella sp., side views; 8-10. Pseudomassilina pacificiensis Cushman, 8-9. Side views, 10. Apertural view; 11. Pyrgo oblonga d'Orbigny, side view; 12-13. Pyrgo sp., side views; 14. Triloculina affinis d'Orbigny, side view; 15-17. Triloculina brongniatiana D'Orbigny, 15-16. Side views, 17. Apertural view; 18-19. Triloculina elongotricarinata D’Orbigny, side views; 20-21. Triloculina fichteliana d'Orbigny, side views; 22-23. Triloculina insignis Brady, side views; 24. Triloculina marioni Schlumberger, side view; 25. Triloculina oblonga Montagu, side view. 
Triloculina plicata Terquem, 1876

(Figure 8. 3-4)

1876 Triloculina plicata TERQUEM: 61, pl. 6, fig. 2.

2005 Triloculina plicata TERQUEM; Rasmussen: 67, pl. 5, fig. 5.

Material: In the present study, this species recorded as frequent in samples 2, 7 and 13.

Geographical distribution: This species was recorded from several areas such as Eastern Mediterranean (Oflaz, 2006), the Dardanelles Strait in Turkey (Meriç et al., 2009) and western Mediterranean Sea (Milker and Schmiedl, 2012).

Triloculina rotunda d'Orbigny, 1826

(Figure 8. 5-6)

1826 Triloculina rotunda D’ORBIGNY: 299 , fig. 4 .

1977 Triloculina rotunda D'ORBIGNY; Lagoe: 106, 129.

Material: In the present study, this form is recorded frequently in samples 2, 5 and 17.

Geographical distribution: Triloculina rotunda d'Orbigny was originally described from the recent deposits the Adriatic Sea, Italy (d'Orbigny, 1826 and 1839). It was later recorded from the shore sands of western India (Bhatia, 1956), the coast of Puerto Rico (Brooks, 1973), the Central Arctic Ocean (Lagoe, 1977), Bermuda islands (Javaux et al., 2003), Indian coast (Devi and Rajashekhar, 2009) and New Caledonia, Southwestern Pacific (Debenay, 2012).

Triloculina terquemiana (Brady), 1884

(Figure 8. 7-9)

1884 Miliolina terquemiana BRADY: 166, pl. 114, fig. 1.

2009 Triloculina barnardi RASHEED; Parker: 358, figs. 260a-m.
Material: In the present study, it is recorded as a rare form in samples 2, 9 and 13 .

Geographical distribution: Brady, 1984, described Triloculina terquemiana from the shallow water of Ceylon and Madagascar. It was later recorded from the shore sands of western India (Bhatia, 1956), Indian coasts (Rana, 2009 and Devi et al., 2009) and Southwestern Pacific (Debenay, 2012).

Triloculina tricarinata d'Orbigny, 1826

(Figure 8. 10-12)

1826 Triloculina tricarinata D'ORBIGNY: 299, pl. 1, fig. 8.

2005 Triloculina tricarinata D'ORBIGNY; Rasmussen: 67, pl. 5, fig. 6.

Material: In the present study, Triloculina tricarinata d'Orbigny occurs as a frequent form in samples 2, 11, 13 and 20.

Geographical distribution: This species was recorded from central Adriatic Sea (Morigi et al., 2005), Eastern Mediterranean (Oflaz, 2006), Central east coast of India (Rana, 2009), southeastern Arabian Sea (Sarkar and Gupta, 2009), Indonesia (Suhartati and Muchlisin, 2012), Aegean Sea (Koukousioura et al., 2012) and Red Sea (Madkour, 2013).

\section{Triloculina trigonula (Lamarck), 1804}

(Figure 8. 13-14)

1804 Miliolites trigonula LAMARCK: 35, pl. 17, fig. 4.

2009 Triloculina trigonula (LAMARCK); Parker: 366, figs. 266a-k; 267a- k.

Material: In the present study, it is recorded as an abundant form in samples 2.8 and 14, and as a rare form in samples 13 and 19.

Geographical distribution: This cosmopolitan species was described from the Eocene of France (Lamarck, 1804). It was later recorded from 
the recent deposits of several parts of the world such as the Gulf of California (Bandy, 1961), the Atlantic Continental Shelf, U.S.A. (Murray, 1969), Bahama West of Andros Island (Todd and low, 1971), Mediterranean coast of Egypt (Samir et al., 2003), Indian coast (Devi and Rajashekhar, 2009), Aegean Sea (Koukousioura et al,. 2012) and coast of Iligan Bay, Mindanao, Philippines (Lacuna, et al., 2013).

Triloculina trihedra Loeblich and Tappan, 1953

(Figure 8. 15-16)

1953 Triloculina trihedra LOEBLICH and TAPPAN: 45, pl. 4. fig. 10.

1980 Triloculina trihedra LOEBLICH and TAPPAN; El-Nakhal: 44, pl. 3, figs. 4- 6.

Material: In the present study, it is found as abundant form in samples 2, 5, 9 and 18 and as a common form in samples 3 and 13.

Geographical distribution: Triloculina trihedra Loeblich and Tappan was described from the recent deposits of the Arctic Ocean, north Alaska and Greenland by Loeblich and Tappan (1953) and Lagoe (1977) and from the Red Sea coastline of Yemen (El-Nakhal, 1980, 1984).

Subfamily: Sigmoilinitinae Luczkowska, 1974

Genus: Sigmohauerina Zheng, 1979

Sigmoihauerina bradyi (Cushman), 1917

(Figure 8. 17-19)

1917 Hauerina bradyi CUSHMAN; p. 62, P1. 23, Figure 2.

1994 Sigmoihauerina bradyi (CUSHMAN); Jones: 27, pl. 11, figs. 12-13.

Material: In the present study, it is recorded as a frequent form in samples 5, 13, 16 and 20.

Geographical distribution: This form was recorded by Cushman, 1917 from the North Pacific Ocean and from the Gulf of Aqaba by Hottinger et al., 1993.
Family: Miliolidae Ehrenberg, 1839

Subfamily: Miliolinae Ehrenberg, 1839 Genus: Rupertlanella Loeblich and Tappan, 1985

Rupertianella rupertiana Brady, 1884

(Figure 8. 20-21)

1884 Rupertianella rupertiana BRADY, 354.

Material: In the present study, Rupertianella rupertiana Brady occurs as an abundant form in samples 2, 5, 12 and 13.

Geographical distribution: It was recorded from Palk Strait, India (Gandhi et al., 2002).

Super family: Alveolinoidea Ehrenberg, 1839

Family: Alveolinidae Ehrenberg, 1839

Genus: Borelis de Montfort, 1808

Borelis schlumbergeri Reichel, 1937

(Figure 8. 24)

1937 Neoalveolina pygmaea (Hanzawa) schlumbergeri - REICHEL: 110, pl. 10, figs. 1-3.

1979 Borelis schlumbergeri REICHEL; Bahafzallah: 182, pl. 15, figs. 11-12.

1997 Borelis schlumbergeri REICHEL; Haig: 270, fig. 3.

Material: In the present study, it is recorded as an abundant form in samples 2, 7, 14 and 19 and as a common form in samples 5 and 13 .

Geographical distribution: This species was originally described by Reichel (1937) from Madagascar. It has been recorded from different areas along the Red Sea coastline (Said, 1949, Bahafzallah, 1979, Hottinger et al., 1993 and Madkour, 2013) and from Exmouth Gulf, Western Australia (Haig, 1997).

Superfamily: Soritoidea Ehrenberg, 1839

Family: Peneroplidae Schultze, 1854

Genus: Coscinospira (Ehrenberg, 1839)

Coscinospira hemprichii Ehrenberg, 1839

(Figure 8. 25-27; Figure 9. 1) 
1839 CoscinospirahemprichiiEHRENBERG: 131 pl. 2, fig. 2.

\section{CoscinospirahemprichiiEHRENBERG;} Yalcin et al.: 38, pl. 3, figs. 1-2.

Material: In the present study, Coscinospira hemprichii Ehrenberg occurs as an abundant form in samples 1, 6, 10 and 13, and as a rare form in samples 2 and 11 .

Geographical distribution: This species was recorded from Yemen (El-Nakhal, 1993), Western Australia (Haig, 1997), Turkey (Yalcin et al., 2006) and New Caledonia, Southwestern Pacific (Debenay, 2012).

Geographical distribution: Peneroplis pertusus (Forskal) was originally described by Forskal (1775) as Nautilus pertusus. It was later recorded from Florida (Buzas and Severin, 1982), Eastern Mediterranean (Oflaz, 2006), Central east coast of India (Rana, 2009), the Dardanelles Strait in Turkey (Meriç et al., 2009), Indonesia (Suhartati and Muchlisin, 2012), Aegean Sea (Koukousioura et al., 2012), the Egyptian Red Sea coast (Madkour, 2013) and from the Philippines (Lacuna, et al., 2013).

Peneroplis planatus (Fichtel and Moll) 1798

(Figure 9. 10-11)

1798 Naatilus planatus FICHTEL AND MOLL: 91-94, pl. 16, figs. a-h.

1988 Peneroplis planatus (FICHTEL AND MOLL); Loeblich and Tappan: 371, pl. 391, figs. 7-8.

2002 Peneroplis planatus (FICHTEL AND MOLL); Hyams et al.: 174, pl. 1, fig. 13.

Material: In the present study, Peneroplis planatus (FICHTEL AND MOLL) occurs as an abundant form in samples 5, 10, 11 and 16, and as a rare form in samples 13 and 20.

Geographicalal distribution: This cosmopolitan species was originally described from the coast of Italy by (Fichtel and Moll, 1798). It was later recorded from southern Thailand (Jumnongthai, 1980), East Coast of India (Gandhi and Rajamanickam, 2002), eastern Mediterranean, (Oflaz, 2006) and Philippines (Lacuna, et al., 2013).

Family: Soritidae Ehrenberg, 1839

Subfamily: Soritinae Ehrenberg, 1839

Genus: Sorites Ehrenberg, 1839

Sorites marginalis Lamarck, 1816

(Figure 9. 12-13)

1816 Sorites marginalis LAMARCK: 196.

1994 Sorites marginalis LAMARCK; Loeblich and Tappan: 62, pl. 112, figs. 1-5.

Material: In the present study, this species is recorded as abundant in samples 2 and 13 and as a frequent form in samples 5 and 15 .

Geographical distribution: This species has been recorded from the Red Sea by (Said, 1949 and Madkour, 2013).

Sorites orbiculus (Forskal), 1775

(Figure 9. 14-15)

1775 Nautilus orbiculus FORSKAL: 125.

1987 Sorites orbiculus (FORSKAL); Baccaert: 70, pl. 27, fig. 2; pl. 28, figs. 1-2; pl. 29, fig. 1.

2009 Sorites orbiculus (FORSKAL); Parker: 336, figs. 244a-g; 245a-h.

Material: In the present study, Sorites orbiculus (Forskal) occurs as a common form in samples 2, 5, 12 and 13.

Geographical distribution: The present species was recorded from several areas worldwide such as Yemeni Red Sea coastline (El-Nakhal, 1980 and 1993), Egyptian Mediterranean coast (Samir et al., 2003), Eastern Mediterranean (Oflaz, 2006), Central east coast of India (Rana, 2009), the Dardanelles Strait in Turkey (Meriç et al., 2009) and Southwestern Pacific (Debenay, 2012). 


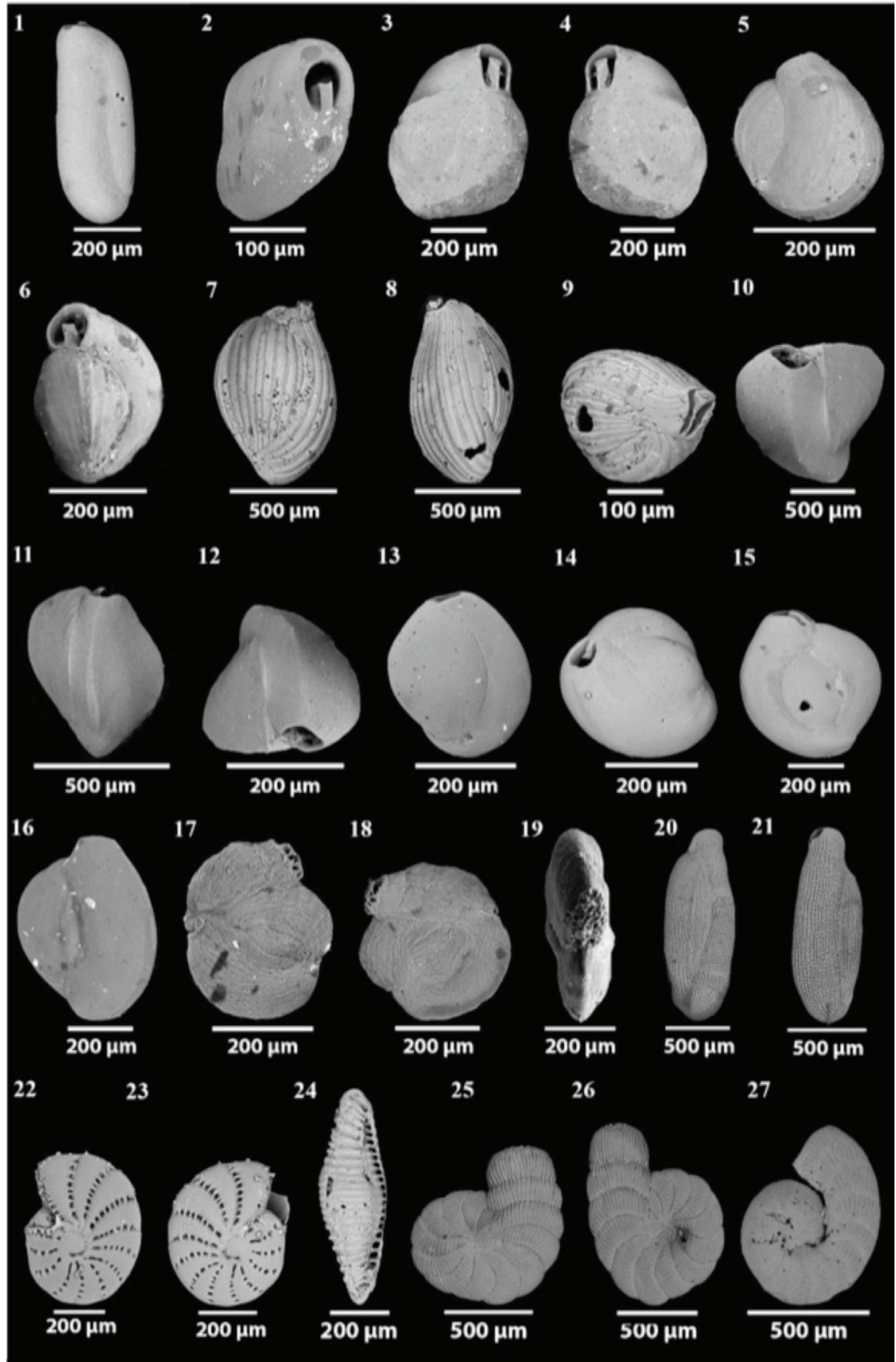

Figure 8. 1-2. Triloculina oblonga Montagu, 1. Side view; 2. Apertural view; 3-4. Triloculina plicata Terquem, side views; 5-6. Triloculina rotunda d'Orbigny, 5. Side views, 6. Apertural view; 7-9. Triloculina terquemiana Brady, 7-8. Side views; 9. Apertural view; 10-12. Triloculina tricarinata d'Orbigny, 10-11. Side views; 12 . Apertural view; 13-14. Triloculina trigonula Lamarck, 13. Side view, 14. Apertural view; 15-16. Triloculina trihedra Loeblich and Tappan, side views; 17-19. Sigmoihauerina bradyi Cushman, 17-18. Side views, 19. Apertural view; 20-21. Repertianella rupertiana Brady, side views; 22-23. Elphidium gerthi Van Voorthuysen, side views; 24. Borelis schlumbergeri Reichel, side view; 25-27. Coscinospira hemprichii Ehrenberg, side views. 
Genus: Peneroplis de Montfort, 1808

Peneroplis arietinus (Batsch) 1791

(Figure 9. 2-4)

1791 Nautilus arietinus BATSCH: 3, pl. VI, figs. $15 \mathrm{~d}-\mathrm{f}$.

1988 Peneroplis arietinus (BATSCH); Loeblich and Tappan: 371, pl. 391, figs. 11-12.

1994 Peneroplis arietinus (BATSCH); Gudmundsson: 113, text-Figs 21-22; pl. 2, fig. 3; pl. 3 , fig. 2.

Material: In the present study, it is recorded as a common form in samples 2, 5, 8 and 13 .

Geographical distribution: Peneroplis arietinus (Batsch) was originally described by Batsch (1791) from recent sand of Italy. It was later recorded from Northeast of Australia (Baccaert, 1987), Southeastern China Sea (Hatta and Ujiie, 1992), eastern Mediterranean, (Oflaz, 2006) and from the Egyptian Red Sea coast (Madkour, 2013).

Peneroplis bradyi Cushman, 1930

(Figure 9. 5-6)

1930 Peneroplis bradyi CUSHMAN: 40, pl. 14, figs. 8-10.

1971 Peneroplis bradyi CUSHMAN; Bock: 33, pl. 13, fig. 8 .

Material: In the present study, it is found as abundant form in samples 2, 9 and 13 and as a rare form in samples 1 and 5 .

Geographical distribution: This form was described from Montego Bay, Jamaica, (Cushman, 1930), and from the Bahama West of Andros Island (Todd and Low, 1971).

Peneroplis pertusus (Forskal), 1775

(Figure 9. 7-9)

1775 Nautilus pertusus FORSKAL: 125.

1917 Peneroplis pertusus (FORSKAL); Cushman: 86, pl. 37, figs. 1-2, 6 .
2009 Peneroplis pertusus (FORSKAL); Parker: 152, figs. 108a-h, 109i-1.

Material: In the present study, it is recorded as a frequent form in samples 3, 5, 13 and 17.

Suborder: Lagenina Delage and Herouard, 1896

Superfamily: Nodosaroidea Ehrenberg, 1838

Family: Nodosariidae Ehrenberg, 1838

Subfamily: Plectofrondiculariinae Cushman, 1927

Genus: Amphimorphina Neugeboren, 1850

Amphimorphina butonensis Keyzer, 1953

(Figure 9. 16-17)

1998 Amphimorphina butonensis KEYZER; Loeblich and Tappan: 114, pl. 44, figs. 12-14.

1999 Amphimorphina butonensis KEYZER; Eagle et al.: 59, fig. 10.

Material: In the present study, Amphimorphina butonensis Keyzer is recorde as a rare form in samples 2, 13 and 16 .

Geographical distribution: This species was recorded from Buton Island, Indonesia by Keyzer, 1953 and then from the Mathesons Bay, Auckland by Eagle et al., 1999.

Family: Ellipsolagenidae Silvestri, 1923

Subfamily: Ellipsolageninae Silvestri, 1923

Genus: Fissurina Reuss, 1850

Fissurina sp.

(Figure 9. 18)

Description: Test is subrounded outline and ovate in section. Wall calcareous, coarser perforations, surface coarsely with a rounded margin; the aperture is terminal at the end of a short neck.

Material: This form is recorded here as a frequent manner in samples 2, 10, 13 and 19. 
Suborder: Rotaliina Delage and Herouard, 1896

Superfamily: Bolivinoidea Glaessner, 1937

Family: Bolivinidae Glaessner, 1937

Genus: Bolivina d'Orbigny, 1839

Bolivina pseudoplicata Heron-Allen and Earland, 1930

(Figure 9. 19-21)

1930 Bolivina pseudoplicata HERONALLEN and EARLAND: 81, pl. 3, figs. 36-40.

2005 Bolivina pseudoplicata HERONALLEN and EARLAND; Rasmussen: 80, pl. 9, figs. 16-17.

Material: In the present study, Bolivina pseudoplicata Heron-Allen and Earland occurs as an abundant form in samples 2, 5 and 14 and as a rare form in samples 8 .

Geographical distribution: This species was recorded from several areas such as Northern New Zealand (Hayward et al., 1999), North American Pacific coast from California (Culver and and Buzas, 1986), France (Debenay et al., 2001) and from the western Mediterranean Sea (Milker et al., 2012).

Bolivina pseudopunctata Höglund, 1947

(Figure 9. 22-24)

1947 Bolivina pseudopunctata HÖGLUND: 273, pl. 24, fig. 5a; pl. 32, figs. 23-24.

2006 Bolivina pseudopunctata HÖGLUND; Lioyd: 323, pl. 2, fig.c.

Material: This species is recorded here as a common in samples 2, 6, 13 and 19.

Geographical distribution: Bolivina pseudopunctata Höglund was recorded from the Caribbean Region (Culver and Buzas, 1982), Hebridean shelf, west of Scotland (Murray, 2003), King George Island, West Antarctica (Majewski, 2007), West Greenland (Lioyd, 2006) and Maldives Ridge, southeastern Arabian Sea (Sarkar, and Gupta, 2009).

Bolivina variabilis (Williamson), 1858)

(Figure 9. 25; Figure 10. 2)

1858 Textularia variabilis WILLIAMSON: 76, pl. 6, figs. 162-163.

1965 Bolivina variabilis (WILLIAMSON); Phleger: 51, pl. 1, fig 8 .

2005 Bolivina variabilis (WILLIAMSON); Debenay et al.: 336, pl. 3, fig. 4.

Material: In the present study, Bolivina variabilis (Williamson) occurs as a frequent form in samples 2 and 7.

Geographical distribution: This species was recorded by Culver and Buzas, 1980, 1982 and 1986 from the North American Atlantic Coast, Caribbean Region and North American Pacific Coast from California respectively. It was recorded also from France (Debenay et al., 2001), Bermuda islands (Javaux, et al., 2003) and Indian coast (Devi and Rajashekhar., 2009).

Superfamily: Buliminoidea Jones, 1875

Family: Siphogenerinoididae Saidova, 1981

Subfamily: Siphogenerinoidinae Saidova, 1981

Genus: Sagrinella Saidova, 1975

Sagrinella lobata Brady, 1881

(Figure 10. 3-5)

1881 Sagrinella lobata BRADY: 58.

1993 Sagrinella lobata BRADY; El-Nakhal: 271.

Material: In the present study, Sagrinella lobata occurs as an abundant form in samples 5, 8 and 13, and as a rare form in samples 2, 15 and 19.

Geographical distribution: Brady (1881) described Sagrinella lobata from the Pacific Ocean and then it was recorded from Salif coast in Yemen, by El- Nakhal, 1993. 


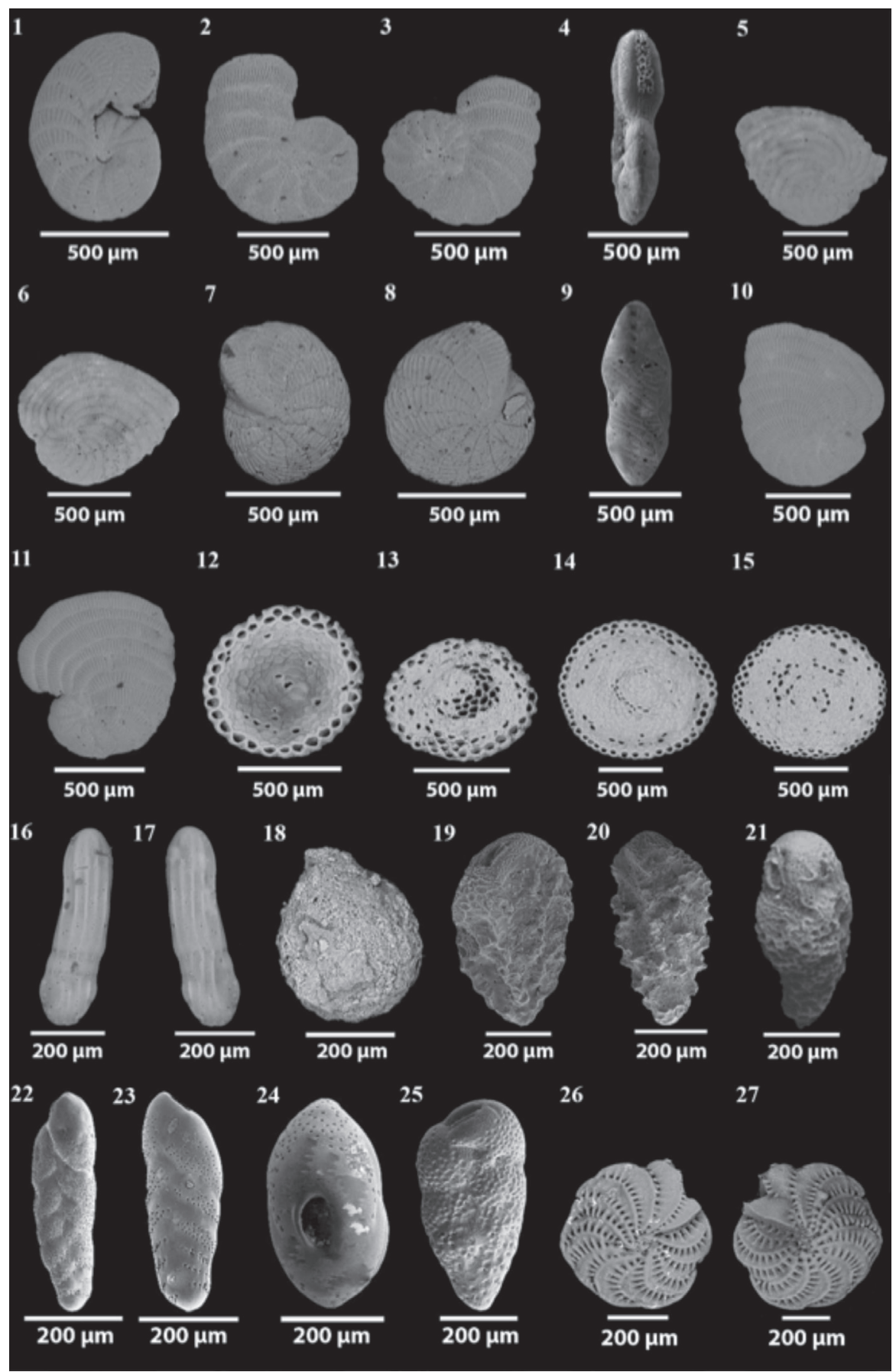

Figure 9. 1- Coscinospira hemprichii Ehrenberg, side view; 2-4. Peneroplis arietinus Batsch, 2-3. Side views, 4. Apertural view; 5-6. Peneroplis bradyi Cushman, side views; 7-9. Peneroplis pertusus Forskal, 7-8. Side views; 9. Apertural view; 10-11. Peneroplis planatus Fichtel and Moll, side views; 12-13. Sorites marginalis Lamarck, side views; 14-15. Sorites orbiculus Forskal, side views; 16-17. Amphimorphina butonensis Keyzer, side views; 18. Fissurina sp., side view; 19-21. Bolivina pseudoplicata Heron- Allen and Earland, 19-20. Side view; 21. Edge view; 22--24. Bolivina pseudopunctata Hoglund, 22-23. Side views, 24. Apertural view; 25. Bolivina variabilis Williamson, side view; 26-27. Elphidium margaritaceum Cushman, side views. 
Family: Reussellidae Cushman, 1933

Genus: Reussella Galloway, 1933

Reussella spinulosa (Reuss) 1850

(Figure 10. 6-7)

1850 Verneuilina spinulosa REUSS: 347, pl. 47, fig. $12 \mathrm{a}-\mathrm{c}$.

2009 Reussella spinulosa (REUSS); Milker et al.: 218, pl. 3, figs. 4-5.

Material: In the present study, this species recorded as frequent in samples 5, 10, 13, and 20.

Geographical distribution: This species was recorded from several areas worldwide such as the North American Atlantic Coast, the Caribbean Region and (Culver and Buzas, 1980 and 1982), east coast of India (Gandhi and Rajamanickam, 2002), the Pakistan continental margin, Arabian Sea (Schumacher et al., 2007) and from Philippines (Lacuna, et al., 2013).

Super Family: Discorboidea Ehrenberg, 1838

Family: Eponididae Hofker, 1951

Subfamily: Eponidinae Hofker, 1951

Genus: Eponides de Montfort, 1808

Eponides repandus (Fichtel and Moll), 1798

(Figure 10. 8-9)

1798 Nautilus repandus FICHTEL and MOLL: 35, pl. 3, figs. a-d.

2009 Eponides repandus (FICHTEL and MOLL); Parker: 603, figs. 429a-f.

Material: In the present study, Eponides repandus Fichtel and Moll occurs as a common form in samples 2, 7 and 13.

Geographical distribution: This species was recorded from several regions such as Karwar, central west coast of India bordering the Arabian Sea (Khare, 1992) and from New Caledonia, Southwestern Pacific (Debenay, 2012).

Family Rosalinidae Reiss, 1963
Genus: Rosalina d'Orbigny, 1826

Rosalina anomala Terquem, 1875

(Figure 10. 10-11)

1973 Rosalina anomala TERQUEM; Haynes: 150, pl. 17, figs. 1-3; pl. 19, fig. 2; text-fig. 28.

2009 Rosalina floridensis CUSHMAN; Milker et al.: 218, pl. 3, figs. 18-19.

Material: In this study, it is recorded as an abundant form in samples 1, 7 and 13, and as a rare form in samples 2, 5 and 11.

Geographical distribution: This species was recorded from several areas such as the Atlantic Ocean (Cushman, 1931), the Hebridean shelf, west of Scotland (Murray, 2003), Kosterfjord, south west Sweden (Wisshak et al., 2006) and from the Western Mediterranean Sea (Milker et al., 2009).

Rosalina bradyi Cushman, 1915

(Figure 10. 12-15)

1991 Rosalina bradyi CUSHMAN; CIMERMAN and LANGER: 66, pl. 71, figs. 1-5.

2008 Rosalina bradyi CUSHMAN; Abu-Zied et al.: 52, pl. 2, figs. 28-29.

Material: Rosalina bradyi Cushman occurs as an abundant form in samples 4 and 6 , and as a frequent form in samples 2, 8 and 13.

Geographical distribution: This species was recorded from several areas worldwide such as Port Joinville Harbor, France (Debenay et al., 2001), Australia (Nobes and Uthicke, 2008), eastern Mediterranean (Abu-Zied et al., 2008), the Dardanelles Strait in Turkey (Meriç et al., 2009) and Indian coast (Devi and Rajashekhar, 2009).

Rosalina globularis d'Orbigny, 1826

(Figure 10. 16-17)

1826 Rosalina globularis D’ORBIGNY: 271, pl. 13, figs. 1-4.

2009 Rosalina globularis D’ORBIGNY; Parker: 718; figs. 504a-1. 
Material: The present species is recorded as a common from samples 5, 7, 13 and 18 .

Geographical distribution: Rosalina globularis D'ORBIGNY was recorded from France (Debenay et al., 2001), Hebridean shelf, west of Scotland (Murray, 2003), southeastern Arabian Sea (Sarkar and Gupta, 2009), Turkey (Meriç et al., 2009) and coastal plains in the Aegean Sea (Koukousioura et al., 2012).

\section{Rosalina sp.}

(Figure 10. 18-19)

Description: Test trochospiral, ovate and convex on the spiral side, peripheral margin broadly rounded; the wall is calcareous, hyaline and perforate; sutures are depressed and backward curved on the spiral side; the first chamber is very big, ovate, convex, and finely perforate, later chambers can be coarsely perforate, About five inflated chambers are visible in the final whorl on the spiral side; umbilical side is evolute with triangular and perforate chambers, umbilicus is open; aperture is an interiomarginal, extraumbilical arched slit, extending from the periphery to the umbilicus.

Material: In the present study, this species recorded as a rare in samples 2 and 13.

Superfamily: Planorbulinoidea Schwager, 1877

Family: Planulinidae Bermúdez, 1952

Genus: Hyalinea Hofker, 1951

Hyalinea balthica (Schroeter), 1783

(Figure 10. 20-21)

1783 Nautilus balthicus SCHROETER: 20, pl. 1, fig. 2.

1988 Hyalinea balthica (SCHROETER); Loeblich and Tappan: 167, pl. 632, figs. 5-8.

2009 Hyalinea balthica (SCHROETER); Frezza and Carboni: 57, pl. 2, fig. 18.

Material: In the present study, Hyalinea balthica Schroeter occurs as a frequent form in samples 1, 5 and 13.
Geographical distribution: This species was recorded from several areas such as Eastern Mediterranean (Parker, 1958), Marmara Sea (Kaminski et al., 2002), the Hebridean shelf, west of Scotland (Murray, 2003), Kallithea Bay, Greece (Rasmussen, 2005) and Northern Tyrrhenian Sea, Italy (Frezza and Carboni, 2009).

Family: Planorbulinidae Schwager, 1877

Subfamily: Planorbulininae Schwager, 1877

Genus: Planorbulina d'Orbigny, 1826

Planorbulina mediterranensis d'Orbigny, 1826

(Figure 10. 22-23)

1826 Planorbulina mediterranensis D'ORBIGNY: 280, pl. 15, figs. 4-6.

2010 Planorbulina mediterranensis D’ORBIGNY; Dias et al.: 844, fig. 2, image 7.

Material: In the present study, this species recorded as a rare in samples 8 and 13 .

Geographical distribution: The present form was recorded from several areas worldwide such as the Caribbean Region (Culver and Buzas, 1982), France (Debenay et al., 2001), Bermuda islands (Javaux and Scott, 2003) and the Dardanelles Strait in Turkey (Meriç et al., 2009).

Family: Cymaloporidae Cushman, 1927

Subfamily: Cymbaloporinae Cushman, 1927

Genus: Cymbaloporella Cushman, 1927

Cymbaloporella tabellaeformis Brady, 1884

(Figure 10. 24-25)

1884 Cymbaloporella tabellaeformis BRADY: 637, pl. 102, figs. 15-18.

2009 Cymbaloporella tabellaeformis BRADY; Sarkar and Gupta: 30, pl. 3, Figure 17.

Material: In the present study, it is found as a frequent form in samples 2, 5, 10, and 19 .

Geographical distribution: This species was identified from Maldives Ridge in southeastern Arabian Sea (Sarkar and Gupta, 2009). 


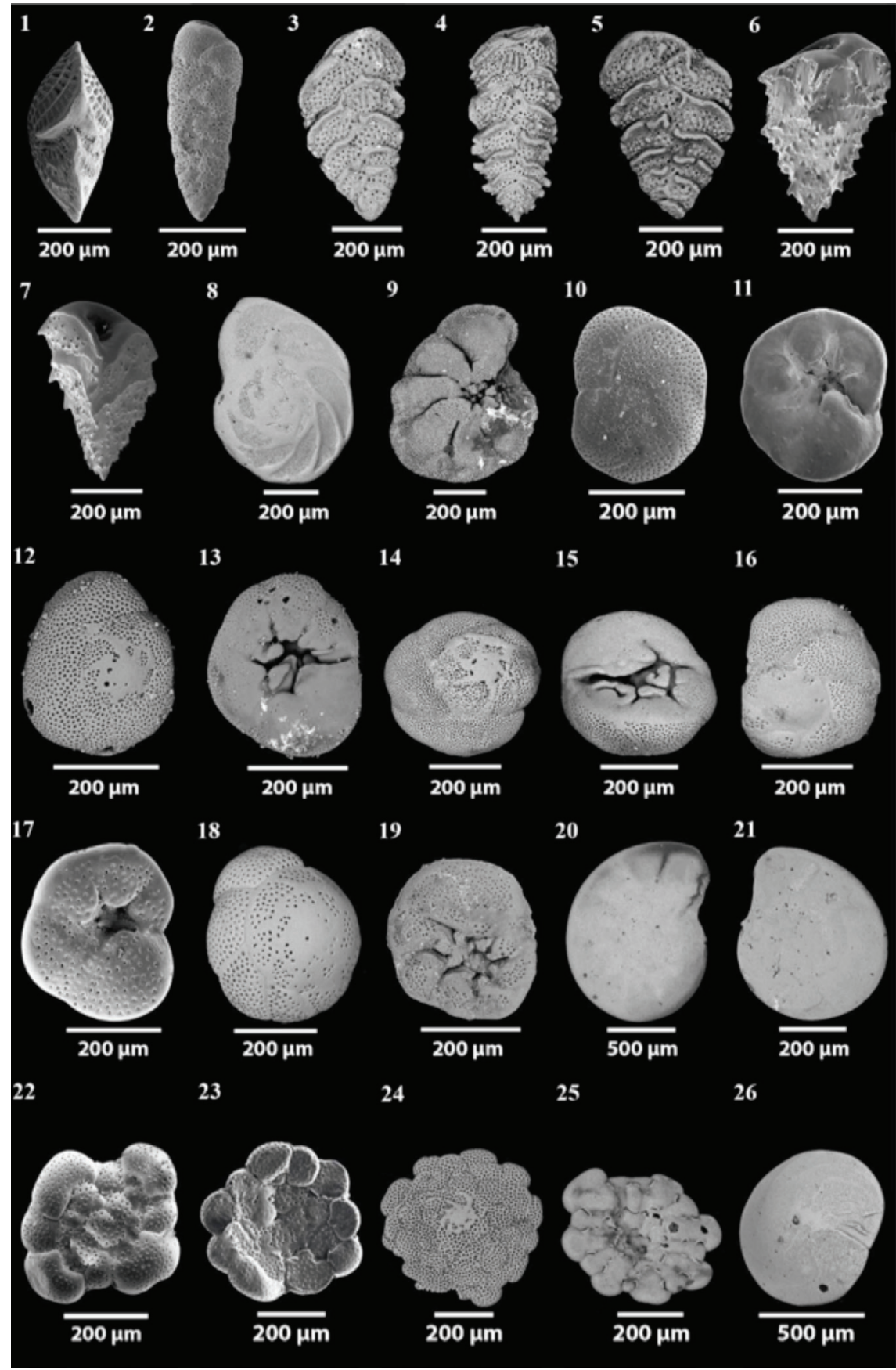

Figure 10. 1- Elphidium margaritaceum Cushman, apertural view; 2. Bolivina variabilis Williamson, side view; 3-5. Sagrinella lobata Brady, side views; 6-7. Reussella spinulosa Reuss, side views; 8-9. Eponides repandus Fichtel and Moll, 8. Spiral side, 9. Umbilical side; 10-11. Rosalina anomala Terquem, 10. Spiral view; 11. Umbilical view; 1215. Rosalina bradyi Cushman, 12, 14. Spiral side views, 13, 15. Umbilical views; 16-17. Rosalina globularis d'Orbigny, 16. Spiral view, 17. Umbilical view; 18-19. Rosalina sp., 18. Spiral view, 19. Umbilical view; 20-21. Hyalinea balthica Schroeter, 20. Spiral view, 21. Umbilical view; 22-23. Planorbulina mediterranensis d'Orbigny, 22. Spiral view, 23. Umbilical view; 24-25. Cymbaloporella tabellaeformis Brady, 24. Side view, 25. Spiral view; 26. Amphistegina lessonii d'Orbigny, spiral view. 
Superfamily: Asterigerinoidea d'Orbigny, 1839

Family: Amphisteginidae Cushman, 1927

Genus: Amphistegina d'Orbigny, 1826

Amphistegina lessonii d'Orbigny, 1826

(Figure 10. 26; Figure 11. 1)

1826 Amphistegina lessonii D’ORBIGNY: 304.

2009 Amphistegina lessonii D’ORBIGNY; Parker: 498, figs. 355a-d.

Material: In the present study, Amphistegina lessonii d'Orbigny occurs as a common form in samples 2, 5 and 13 .

Geographical distribution: This species was recorded from north American Atlantic Coast and the Caribbean Region by Culver and Buzas (1980, 1982), Bermuda islands (Javaux et al., 2003), the central Great Barrier Reef of Australia (Horton et al., 2007) and Red Sea coast (Madkour, 2013).

Amphistegina lobifera Larsen, 1976

(Figure 11. 2-3)

1976 Amphistegina lobifera LARSEN: 4-6, pl. 3, figs. 1-5; pl. 7, fig. 3; pl. 8, fig. 3 .

2009 Amphistegina lobifera LARSEN; Parker: 498, figs. 355: e-o.

Material: In the present study, it is found as a rare form in samples 2, 5, 10 and 13.

Geographical distribution: This species was recorded from Haifa Bay (Yanko et al. 1993), Arabian Gulf (Cherif et al., 1997) and Southwestern Pacific (Debenay, 2012).

Amphistegina radiata (Fichtel and Moll), 1798

(Figure 11. 4-5)

1798 Nautilus radiata FICHTEL and MOLL: 58, pl. 8, figs. a-d.

2009 Amphistegina radiata (FICHTEL and MOLL); Parker: 499, fig. 356: a-j.
Material: In the present study, this species recorded as frequent in samples 2, 5 and 16.

Geographical distribution: This species was recorded from several regions such as India (Khare, 1992 and Gandhi and Rajamanickam, 2002), New Guinea (McCloskey, 2009) and Southwestern Pacific (Debenay, 2012).

Super family: Nonionoidea Schultze, 1854

Family: Nonionidae Schultze, 1854

Sub family: Nonioninae Schultze, 1854

Genus: Nonion de Montfort, 1808

Nonion fabum (Fichtel and Moll), 1798

(Figure 11. 6-8)

1798 Nautilus faba FICHTEL and MOLL: 103, pl. 19: b-c.

1988 Nonion fabum (FICHTEL and MOLL); Loeblich and Tappan: 179, pl. 690, figs. 1-7.

2005 Nonion fabum (FICHTEL AND MOLL); Rasmussen: 102, pl. 16, fig. 5.

Material: In the present study, Nonion fabum (Fichtel and Moll) occurs as a common form in samples 2, 7 and 13 .

Geographical distribution: This species was recorded from The Guadiana shelf, Southwestern Iberia (Mendes et al., 2004), Kallithea Bay, Greece (Rasmussen, 2005), Namibia (Leiter, 2008) and western Mediterranean Sea (Milker et al., 2009).

Superfamily Rotalioidea Ehrenberg, 1839

Family Rotaliidae Ehrenberg, 1839

Subfamily Pararotaliinae Reiss, 1963

Genus: Neorotalia Bermúdez 1912

Neorotalia calcar d'Orbigny, 1839

(Figure 11.9-11)

1993 Neorotalia calcar D'ORBIGNY; Hottinger et al.: 140, pl. 199, figs. 1-10. 
2009 Neorotalia calcar D’ORBIGNY; Devi and Rajashekhar: 33, fig. 11f.

Material: In the present study, Neorotalia calcar d'Orbigny occurs as an abundant form in samples 2 and 8 , and as a rare form in samples 13 .

Geographical distribution: This species was recorded from several areas such as the Caribbean Region (Culver and Buzas, 1982), Indonesia (Renema, 2003), Indian coast (Devi and Rajashekhar, 2009) and Southwestern Pacific (Debenay, 2012).

Genus: Pararotalia le Calvez, 1949

Pararotalia cf. P. ozawai (Asano), 1951

(Figure 11. 12-13)

1951 Rotalia ozawai ASANO: 15, figs. 115117.

1965 Pararotalia ozawai (ASANO); Todd: 29, pl. 9, fig. 1: a-c.

Material: In the present study, this species recorded as a rare in samples 3 and 13.

Geographical distribution: Asano, 1951 described Pararotalia ozawai from Japan then it was recorded from the tropical Pacific by Todd, 1965.

Subfamily: Ammoniinae Saidova, 1981

Genus: Ammonia Bruennich, 1772

Ammonia aoteana (Finlay), 1940

(Figure 11. 14-15)

1940 Streblus aoteanus FINLAY: 461.

2004 Ammonia aoteana (FINLAY); Hayward et al.: pl. 2, fig. T5; pl. 3, fig. T5; pl. 4, fig. T5.

2009 Ammonia aoteana (FINLAY); Parker: 480, fig. 344: a-h.

Material: In the present study, Ammonia aoteana (Finlay) occurs as an abundant form in samples 3, 7 and 13 and as a rare form in samples 4 and 18.
Geographical distribution: This species was recorded from the central Great Barrier Reef of Australia (Horton et al., 2007) and New Caledonia, Southwestern Pacific (Debenay, 2012).

Ammonia beccarii (Linné), 1758

(Figure 11. 16-19)

1758 Nautilus beccarii LINNÉ: 710.

2005 Ammonia beccarii (LINNÉ); Debenay et al.: 334, pl. 2, fig. 17

2010 Ammonia beccarii (LINNÉ); Issa: 6, pl. 1, fig. 10 .

Material: Ammonia beccarii (LINNÉ) is recorded with different forms in samples 1, 3, 5, 9, 13, 14, 16, 19 and 20.

Geographical distribution: This species was recorded by Culver and Buzas (1980 and 1982) from the North American Atlantic Coast and the Caribbean region. Also it was identified from North American Pacific Coast from California (Culver, 1986), Red Sea coastlines (El-Nakhal, 1993 and Madkour, 2013), west of Scotland (Murray, 2003) and from the Guadiana shelf, southwestern Iberia (Mendes et al., 2004).

\section{Ammonia convexa (Collins), 1958}

(Figure 11. 20-21)

1958 Streblus convexus COLLINS: 414, pl. 5, figs. 10: a-c.

1987 Ammonia convexa (COLLINS); Baccaert: 232, pl. 94, fig. 6.

2008 Ammonia convexa (COLLINS); Nobes and Uthicke: 31, fig. 35.

Material: In the present study, it is found as a rare form in samples 2, 5 and 13.

Geographical distribution: Ammonia convexawas recorded from the Great Barrier Reef, Australian (Nobes and Uthicke, 2008) and Southwestern Pacific (Debenay, 2012). 
Ammonia parkinsoniana (d'Orbigny), 1839

(Figure 11. 22-23)

1839 Rosalina parkinsoniana D’ORBIGNY: 99, pl. 4, figs. 25-27.

1993 Ammonia parkinsoniana (D'ORBIGNY); Sgarrella and Moncharmont Zei: 228, pl. 20, figs. 3-4.

2006 Ammonia parkinsoniana (D’ORBIGNY); Avsar et al.: 133, pl. 3, figs. 1516.

Material: Ammonia parkinsoniana (d'Orbigny) occurs here as a frequent form in samples 2, 5 and 13.

Geographical distribution: This species was recorded from several areas such as the Caribbean Region (Culver and Buzas, 1982), Biscayne Bay in Florida from Atlantic ocean (Ishman, et al., 1997), the central Adriatic Sea (Morigi et al., 2005), Aegean Sea (Koukousioura et al,. 2012).

Family: Elphidiidae Galloway, 1933

Subfamily: Elphidiinae Galloway, 1933

Genus: Elphidium de Montfort, 1808

Elphidium aculeatum (d'Orbigny), 1846

(Figure 11. 24-25)

1846 Polystomella aculeata D'ORBIGNY: 131, pl. 6, figs. 27-28.

1991 Elphidium aculeatum (D’ORBIGNY); Cimerman and Langer: 77, pl. 89, figs. 1-4.

2005 Elphidium aculeatum (D'ORBIGNY); Rasmussen: 108, pl. 18, fig.12.

Material: In the present study, this species recorded as an abundant in samples 3, 5 and 13, and as a rare form in samples 17.

Geographical distribution: Elphidium aculeatum (D'ORBIGNY) was recorded from Kallithea Bay Greece (Rasmussen. 2005), the Dardanelles Strait in Turkey (Meriç et al, 2009) and western Mediterranean Sea (Milker et al., 2012).

Elphidium advenum (Cushman), 1922

(Figure 6. 1; Figure 5. 26-27)

1922 Polystomella advena CUSHMAN: 56, pl. 9, figs. 11-12.

1933 Elphidium advenum (CUSHMAN); Cushman: 50, pl. 12, figs. 1-3.

2005 Elphidium advenum (CUSHMAN); Rasmussen: 108, pl. 18, figs. 13-15.

Material: In the present study, it is recorded as a frequent form in samples 5, 8 and 13 .

Geographical distribution: This species was originally described by Cushman (1922) from southern Florida. It has been recorded from the Red Sea (Said, 1949 and Madkour, 2013), Caribbean Region (Culver and Buzas, 1982), east coast of India (Gandhi and Rajamanickam, 2002), Southern Iraq (Al-Ali et al., 2010) and Aegean Sea (Greece) (Koukousioura et al,. 2012).

Elphidium crispum (Linné), 1758

(Figure 4. 26-27)

1758 Nautilus crispum LINNÉ: 709.

1933 Elphidium crispum (LINNÉ); Cushman: 47, pl. 11, fig. 4.

2009 Elphidium crispum (LINNÉ); Frezza and Carboni: 55, pl. 1, fig. 16.

Material: Elphidium crispum (Linné) occurs as a common form in samples 2, 5 and 13.

Geographical distribution: This species was recorded from several areas Worldwide such as France (Debenay et al., 2001), southwestern Iberia (Mendes et al., 2004), the central Adriatic Sea (Morigi et al., 2005), southwestern coasts of Turkey (Meriç et al., 2009) and Mindanao, Philippines (Lacuna, et al., 2013).

Elphidium gerthi Van Voorthuysen, 1957

(Figure 8. 22-23) 
1957 Elphidium gerthi VAN VOORTHUYSEN: 32, pl. 23, fig. 12: a-b.

2003 Elphidium gerthi VAN VOORTHUYSEN; Murray: 21, figs. 7-8.

Material: In the present study, it is found as a frequent form in samples 3, 5 and 16.

Geographical distribution: This species was recorded in Marmara Sea (Kaminski et al., 2002), Hebridean shelf, west of Scotland (Murray, 2003), and Indian coast (Devi and Rajashekhar, 2009).

Elphidium macellum (Fichtel and Moll), 1798

(Figure 6. 14-16)

1798 Nautilus macellus FICHTEL AND MOLL: 66, pl. 10, figs. e-g.

1988 Elphidium macellum (FICHTEL AND MOLL); Loeblich and Tappan: 199, pl. 789, figs. $1-5$.

2009 Elphidium macellum (FICHTEL AND MOLL); Devi and Rajashekhar: 35, figs. b-c.

Material: This species is recorded as a common in samples 3, 5 and 15.

Geographical distribution: This species was recorded from several areas such as the north American Atlantic coast (Culver and Buzas, 1980), Marmara sea (Kaminski et al., 2002), Italy (Fiorini, 2004), Greece (Rasmussen, 2005), southwestern coasts of Turkey (Meriç et al., 2009) and Indian coast (Devi et al., 2009).

Elphidium margaritaceum Cushman, 1930

(Figure 9. 26-27; Figure 10. 1)

1930 Elphidium advenum CUSHMAN var. margaritaceum Cushman: 25, pl. 10, fig. 3.

Material: In the present study, Elphidium margaritaceum Cushman occurs as a rare form in samples 2, 7 and 13.
Geographical distribution: This species was recorded from Atlantic Ocean (Cushman, 1930), the Caribbean region (Culver and Buzas, 1982), the gulf of Naples (Italy) (Sgarrella and Moncharmont Zei, 1993), the Gulf of Kalloni, Greece (Debenay et al., 2005), Central east coast of India (Rana, 2009) and the western Mediterranean (Milker, 2009).

\section{CONCLUSION}

Twenty beach sand samples have been collected from the Bir Ali Beach, Yemeni Arabian Sea coastline to identify the benthic foraminiferal species in this area. The systematic position of recorded foraminiferal species is applied to identify one hundred and eleven benthic foraminiferal species.

The recorded species are distributed with different percentages on the foraminifera suborders with a notacible ratio of Miliolina suborder in particular the genus Quinqueloculina. The foraminiferal assemplage of the study area reflected a remarkable similarity with the species identified in previous studies from the Arabian Sea, the Indian Ocean, the Red Sea and the Mediterranean Sea.

\section{ACKNOWLEDGEMENTS}

Authors are deeply indebted to the technicial team in the SEM Unit, the Egyptian mineral resources authority (Central Laboratories Sector), Geza-Egypt for their cooperation during the photographing of foraminiferal samples. We are thankful to the two reviewers for their constructive comments and critical remarks for the improvement of the text. 


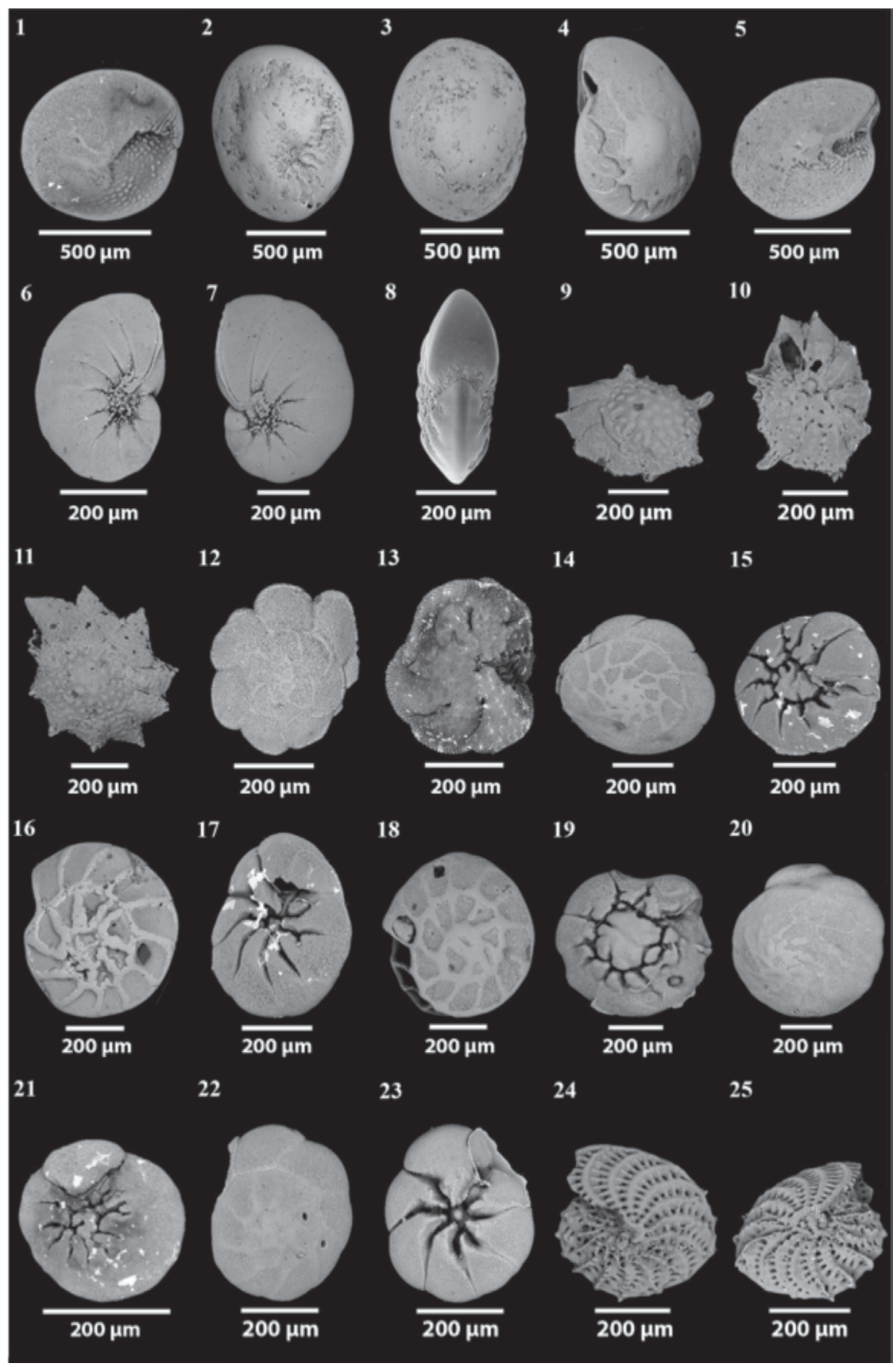

Figure 11. 1- Amphistegina lessonii d'Orbigny, umbilical side; 2-3. Amphistegina lobifera Larsen, 2. Spiral side, 3. Umbilical view; 4-5. Amphistegina radiata Fichtel and Moll, 4. Spiral view, 5. Umbilical view; 6-8. Nonion fabum Fichtel and Moll, 6. Spiral view, 7. Umbilical view, 8. Apertural view; 9-11. Neorotalia calcar d'Orbigny, 9, 11. Spiral view, 10. Umbilical view; 12-13. Pararotalia cf. P. ozawai Asano, 12. Spiral view, 13. Umbilical view; 14-15. Ammonia aoteana Finlay, 14. Spiral view, 15. Umbilical view; 16-19. Ammonia beccarii Linné, 16-18. Spiral views; 19. Umbilical views; 20-21. Ammonia convexa Collins, 20. Spiral side, 21. Umbilical view; 22-23. Ammonia parkinsoniana d'Orbigny, 22. Spiral view, 23. Umbilical view; 24-25. Elphidium aculeatum d'Orbigny, side views. 


\section{REFERENCES}

Abu-Zied, R.H., Rohling, E.J., Jorissen, F.J., Fontanier, C., Casford, J.S.L. and Cooke, S., 2008. Benthic foraminiferal response to changes in bottom-water oxygenation and organic carbon flux in the eastern Mediterranean during LGM to Recent times. Journal of Marine Micropaleontology, 67, 46-68.

Al-Ali, R. A., Al- Shaikhly, S. S., and Al- Marsoumi1, A. M. H., 2010. Study of foraminiferal species in recent sediments in Shatt Al- Arab banks, the coast Khor Abdullah and Khor Al-Zubair, Southern Iraqi Journal Basrah Research, 36 (4).

Al-Hitmi, H. H., 2000. Recent benthic foraminifera from the local water of Qatar, Arabian Gulf. Qatar University, Science Journal, 20, 167- 179.

Al-Wosabi, M, A., Mohammed, M, A. and Al-Kadasi, W, M., 2011. Recent Foraminifera from Socotra Island, Indian Ocean, Yemen. Journal of Natural and Applied Sciences, Thamar University, Yemen, 4, 01-32.

Ariza, M. S., 1988. Study of agglutinated foraminifera from the motril-nerja littoral region, Spain. Abh. Geol, 41, 301-305.

Asano, K., 1951. Illustrated catalogue of Japanese Tertiary smaller foraminifera. Petroleum Branch, Natural Resources Section, Supreme Commander for the Allied Powers, Tokyo, 183.

Avsar, N., Aksu, A. and Dincer, F., 2006. Benthic foraminiferal assemblage of Erdek Bay (SW Marmara Sea). Yerbilimleri 27 (3), 125-141.

Avsar, N., Meric, E., Cevik, M.G. and Dincer, F., 2009. Recent benthic foraminiferal assemblages on the continental shelf off the Büyük Menderes river delta (W Turkey). Yerbilimleri, 30, 127-144.

Baccaert, J., 1987. Distribution patterns and taxonomy of benthic foraminifera in the Lizard Island Reef Complex, northern Great Barrier Reef, Australia. Unpublished PhD Thesis, University of Liège, 3 vols, 109pls.

Bahafzallah, A. A. K., 1979. Distribution, Ecology and systematics of recent benthic foraminifera from Jeddah Bay, Red Sea. PhD Thesis, University of Bristol.

Bandy, O. L., 1953. Ecology and paleoecology of some California Foraminifera. Part I. The frequency distribution of recent Foraminifera of California. Journal of Paleontology, 27 (2), 161-182.

Bandy, O. L., 1961. Distribution of I $>$ ornminifera. Radiolaria and diatoms in sediments of the Gulf of California. Journal of Micropaleontology, 7, 1-26.

Batsch, A.I.G.C., 1791. Sechs Kupfertafeln mit Conchylien des Seesandes. Gezeichnet und gestochen von A. J. G. K. Batsch, Jena, 6pls, 3, 5.

Bermudez, P. J., 1952. Estudio sistematico de los foraminiferos rptaliformes. Bulletin de Geologia Venezuela, 2(4), 1-230.

Beydoun, Z, R., 1966. Eastern Aden Protectorate and part of Dhufar In: Geology of the Arabian Peninsula. United State Geological Survey Proffisional Paper 560-H, Washington, 1-49.

Bhalla, S.N. and Nigam, R., 1979. A note on recent foraminifera from Calongute beach sands. Goa. Bulletin Indian Geologists Association, 12 (2): 239- 240.

Bhatia, S.B., 1956. Recent foraminifera from shore sands of western India. Contribution from the Cushman Laboratory for Foraminiferal Research, 7, 15-24.

Bock, W.D., 1971. A handbook of the benthonic foraminifera of Florida Bay and adjacent waters. Miami Geological Society, Memoir 1, 1-92.

Brady, H.B., 1879. Notes on some Retieularian Rhizopoda of the 〈Challenger〉 expedition. Part II. Additions to the knowledge of porcellanous and hyaline types. Quaternary Journal of the Microscopical Science, 19 (new Series), 261-299.

Brady, H. B., 1881. Notes on some reticularian Rhizopoda of the «Challenger» expedition, Part 3. Quaternary Journal of the Microscopical Science, 21 (new series), 31-71.

Brady, H. B., 1884. Report on the foraminifera dredged by H. M. S. Challenger, during the years 18731876 , in Report on the Scientific Results of the Voyage of the H. M. S. Challenger during the years 1873-1876. Zoology, 9.

Brooks, W., 1973. Distribution of Recent foraminifera from the southern coast of Puerto Rico. Micropaleontology, 20, 236-244.

Bruennich, M. T., 1771. M. T. Brunnich zoologiae fundamenta. Hafnine et Lipsiae: Grunde I dyeloeren. 
Brummer, G. J. A. and Kroon, D., 1988. Planktonic foraminifers as tracers of ocean climate history. Free University Press, Amsterdam, 6-346.

Buzas, M. A. and Severin, K. P., 1982. Distribution and Systematics of foraminifera in the Indian River, Florida. Smithsonian contributions to the marine sciences, 16(i-iii), 1-73.

Cameron, A, A., 1995. Recent foraminifera from the continental shelf and slope off kaikoura, New Zealand. New Zealand Natural Sciences, 22, 2742.

Caton-Thompson, G. and Gardner, E. W., 1939. Climate, irrigation, and early man in Hadhramaut. Geographicalal Journal, 93, 18-35.

Chapman, F., 1895. On some foraminifera obtained by the Royal Indian Marine〉 Surveys 〈Investigator〉 from the Arabian Sea, near Laccadive Islands. Proceeding of Zoological Society, London, 1, $1-55$.

Cherif, O. H., AL-Ghadban, A. and Al-Rifaiy, I. A., 1997. Distribution of foraminifera in the Arabian Gulf. Micropaleontology, 43(3), 253-280.

Cimerman, F. and Langer, M. R., 1991. Mediterranean foraminifera. Ljubljana, Slovenska Akademija Znanosti in Umetnosti, 118pp.

Clemens, S., Prell, W. D., Murray, D., Shimmield, G. and Weedon, G., 1991. Forcing mechanisms of the Indian Ocean monsoon. Nature, 353, 720-725.

Collins, A. C., 1958. Foraminifera, Great Barrier Reef Expedition (1928- 29). Scientific Report, 6, 335437.

Costa, O.G., 1856. Paleontologia del regno di Napoli, Parte II. Atti dell Accademia Pontaniana Napoli, 7(2), 113-378.

Culver, S. J. and Buzas, M. A., 1980. Distribution of Recent Benthic Foraminifera off the North American Atlantic Coast. Smithsonian Contributions to the Marine Sciences, 6, 512.

Culver, S. J. and Buzas, M. A., 1982. Distribution of Recent Benthic Foraminifera in the Caribbean Region. Smithsonian institution press, Washington, 382.

Culver, S. J. and Buzas, M. A., 1986. Distribution of Recent Benthic Foraminifera off the North American Pacific Coast from California to Baja.
Smithsonian contributions to the marine sciences 26, 234.

Cushman, J. A., 1910. A monograph of the foraminifera of the North Pacific Ocean, Part 1: Astrorhizidae and Lituolidae. Bulletin of the United States National Museum, 71 (1), 1-134.

Cushman, J. A., 1911. A monograph of the foraminifera of the North Pacific Ocean. Pt. 2. Textulariidae. Bulletin of the United States National Museum, 71 (2), 1-108.

Cushman, J. A., 1915. A monograph of the foraminifera of the North Pacific Ocean. Part 5, Rotaliidae. Bulletin of the United States National Museum, $71(5), 1-87$.

Cushman, J. A., 1917. A monograph of the foraminifera of the North Pacific Ocean, Part 6, Miliolidae. Bulletin of the United States National Museum, 71 (6), 1-108.

Cushman, J. A., 1922. Shallow-water foraminifera of the Tortugas Region. Publications of the Carnegie Institution Washington, 311, Department of Marine Biology, 17, 1-85.

Cushman, J. A., 1924. Samoan Foraminifera. Carnegie Institution of Washington, No. 342, Department of Marine Biology, 21, 1-75.

Cushman, J. A., 1927. An outline of a re-classification of the foramininifera. Contribution from the Cushman Laboratory for Foraminiferal Research, 3, 1-105.

Cushman, J. A., 1929. The foraminifera of the Atlantic Ocean, Part 6: Miliolidae, Ophthalmidiidae, Fischerinidae. Bulletin of the United States National Museum, 104 (6), 1-129.

Cushman, J.A., 1930. The foraminifera of the Atlantic Ocean. Bulletin of the United States National Museum, 104 (7), 1-79.

Cushman, J. A., 1931. The foraminifera of the Atlantic Ocean, Part 8: Rotaliidae, Amphisteginidae, Calcarinidae, Cymbalporettidae, Globorotallidae, Anomalinidae, Planorbulinidae, Pupertiidae and Homotremidae. Bulletin of the United States National Museum, 104 (8), 1-179.

Cushman, J. A., 1932. The foraminifera of the tropical Pacific collections of the "Albatross»"1899-1900, Part 1: Astrorhizidae to Trochamminidae. Bulletin of the United States National Museum, 161, 1-88. 
Cushman, J. A., 1933. The foraminifera of the tropical Pacific collections of the «Albatross» 1899-1900, Part 2: Lagenida to Alveolinellidae. Bulletin of the United States National Museum, 161, 1-79.

Cushman, J. A., 1944. Foraminifera from the shaloow water of the New England coast. Special Publications Cushman Laboratory for Foraminiferal Research, 12, 1-37.

Cushman, J. A., 1946. The Genus Hauerina and its species. Contributions from the Cushman Laboratory for Foraminiferal Research, 22, 2-15.

Cushman, J. A., 1947. New species and varieties of foraminifera from off the southeastern coast of the United States. Contributions from the Cushman Laboratory for Foraminiferal Research, 23, 86-92.

Cushman, J.A., and LeRoy, L. W., 1939. Cribrolinoides, a new genous of the foraminifera, its development and relationshios. Contributions from the Cushman Laboratory for Foraminiferal Research, 15, 15-19.

Cushman, J. A. and Todd, R., 1944. The genus Spiroloculina and its species. Cushman Laboratory for Foraminiferal Research, Special Publication 1, 1-82.

Debenay, J. P., 2012. A guide to 1,000 Foraminifera from Southwestern Pacific: New Caledonia. Publications Scientifiques du Muséum, Paris, 378.

Debenay, J. P., 2013. A guide to 1,000 Foraminifera from the Southwestern Pacific New Caledonia. IRD Editions. Publication Scientifique du Museum, CP41, 383.

Debenay, J. P., Millet, B. and Angelidis, M. O. 2005. Relationships between foraminiferal assemblages and hydrodynamics in the Gulf of Kalloni, Greece. Journal of Foraminiferal Research, 35, 327-343.

Debenay J. P., Tsakiridis E., Soulard r. and GrosseL H., 2001. Factors determining the distribution of foraminiferal assemblages in Port Joinville Harbor (îled'Yeu, France): the influence of pollution. Marine Micropaleontology, 43, 75-118.

Defrance, J. L. M., 1824. Dictionnaire des Sciences Naturelles, Vol. 32, moll-morf. Strasbourg: F. G. Levrault 567pp.

Delage, Y. and Herouard, E., 1896. Tarite de Zoologie Concrete, Vol. 1, La Cellute et les Protozoaires, Paris: Schlecher Freres.
Devi, G. S. and Rajashekhar, K. P., 2009. Intertidal foraminifera of Indian coast. A scanning electron photomicrograph illustrated catalogue, Journal of Threatened Taxa, 1(1), 17-36.

Dias, B. B., Hart, M. B., Smart, C.W. and Hall-Spencer, J. M., 2010. Modern seawater acidification: the response of foraminifera to high- $\mathrm{CO}_{2}$ conditions in the Mediterranean Sea. Journal of the Geological Society, London, 167, 843-846.

Eagle, M. K., Hayward, B. W., Grant-Mackie, J. A. and Gregory, M. R., 1999. Fossil communities in an early Miocene transgressive sequence, Mathesons Bay, Leigh, Auckland. Tane, 37, 43-68.

Ehrenberg, C. G., 1838. Uber dem blossen Auge unsichtbare kalkthierchen und Kieselthierchen als Hauptbestandtheile der Kreidegebirge, Bericht über die zu Bekanntmachung geeigneten Verhandlungen der Königlichen Preussischen Akademie der Wissenschaften zu Berlin, 1838, 192-200.

Ehrenberg, C. G., 1839. Uber die Bildung der Kreidefelsen und des Kreidemergels durch unsichtbare Organismen. Physikalische Abhandlungen der Koniglichen Akademie der Wissenschaften zu Berlin, 59-147.

Eichwald, C.E. von, 1830. Zoologia specialis. Vol. 2. Vilnae: D. E. Eichwaldus, 1-323.

Ellis, B. F. and Messina, A. R., 1940. Catalogue of foraminifera. American Museum of National History. Special Publication (New York), with supplements.

El-Nakhal, H. A., 1980. Recent foraminifera from the seashores of Yemen Arab Republic, part 2, the genus Quinqueloculina. Journal of College of Science, Riyadh University, 2. 147-170.

El-Nakhal, H. A., 1984. Recent foraminiferida from the sea shores of Yemen Arab Republic Part 1, the genus Quinqueloculina. Journal of College of Science, Riyadh University, 25 (1/2), 45-58.

El-Nakhal, H. A., 1993. Recent foraminiferida from the sea shores of Yemen Arab Republic Part 3, the remaining genera. Dirasat Yamanyyah, 49, 302368.

Erbacher, J. and Nelskamp, S., 2006. Comparison of benthic foraminifera inside and outside a sulphur-oxidizing bacterial mat from the present 
oxygen-minimum zone off Pakistan (NE Arabian Sea): Deep Sea Research, Part I: Oceanographic Research Papers, 53, 751-775.

Fantozzi, P. L. and Sgavetti, M., 1998. Tectonic and sedimentary evolution of the eastern Gulf of Aden margins: new structural and stratigraphic data from Somalia and Yemen. In: Purser, B. H., and Bosence, D. W. J. (ed.) Sedimentation and tectonics in rift basins, Red Sea-Gulf of Aden. London, Chapman and Hall, 56-76.

Fichtel, L. and Moll, J. P., 1798. Testacea microscopica aliaqueminuta generibus Argonauta et Nautilus, Wien, Osterreich, Camesina (Reprinted, 1803).

Finlay, H. J., 1940. New Zealand foraminifera; Key species in stratigraphy-No 4. Transactions and Proceedings of the Royal Society of New Zealand, 69, 448-472.

Fiorini, F., 2004. Benthic foraminiferal associations from upper Quaternary deposits of southeastern plain, Italy. Micropaleontology, 50, 45-58.

Forskal, P., 1775. Descriptiones animalium. Hauniae. Carsten Niebuhr, Copenhagen.

Frezza, V. and Carboni, M. G., 2009. Distribution of recent foraminiferal assemblages near the Ombrone River mouth (Northern Tyrrhenian Sea, Italy). Revue de micropaleontology, 52, 43-66.

Galloway, J. J., 1933. A Manual of Foraminifera, Bloomington: Principal Press. (In Loeblich an tappan, 1988).

Gandhi, S., Rajamanickam, G. V. M. and Nigam, R., 2002. Taxonomy and distribution of benthic foraminifera from the sediments off Palk Strait, Tamil Nadu, East Coast of India. Journal of the paleontological Society of India, 47, 47-64.

Germeraad, J. H., 1946. Geology of central Seran, in L. Rutten, and W. Hotz. Geological, Petrographical and Paleontological Results of Explorations Carried Out from September 1917 till 1919 in the Island of Cerma, ser. 3 (Geology), no. 2. Amsterdam: J. H. de Bussy, 7-135.

Glaessner, M. F., 1937. Die Entfaltung der Foraminiferenfamilie Buliminidae, Problemy Paleontologii. Paleontologicheskaya Laboratoriya Moskovskogo Gosudarstvennogo Universiteta, 2-3, 411-422.
Graham, J. and Militante, P., 1959. Recent foraminifera from the Puerto Galera area, northern Mindoro, Philippines. Stanford University Publications, (Geological), 6 (2), 1-170.

Gudmundsson, G., 1994. Phylogeny, ontogeny and systematics of recent Soritacea Ehrenberg 1839 (Foraminiferida). Micropaleontology, 40 (2), 101155.

Haig, D. W., 1988. Miliolid foraminifera from inner neritic and mud facies of the Papuan Lagoon. Journal of Foraminiferal Research, 18, 203-236.

Haig, D. W., 1997. Foraminifera from Exmouth Gulf, Western Australia. Journal of the Royal Society of Western Australia, 80, 263-280.

Haman, D., 1966. On some recent foraminifera from the Faeroe Island. Denmark. Contribution from the Cushman Laboratory for Foraminiferal Research, 17(2), 67 - 70 .

Hatta, A. and Ujiie, H., 1992. Benthic foraminifera from Coral Seas between Ishigaki and Iriomote Islands. Southern Ryukyu Island Arc, Northwestern Pasific. Bulletin of the Colloge of Science, University of Ryukyus, 53, 49-119.

Haynes, J. R., 1973. Cardigan Bay recent foraminifera. Bulletin of the British Museum Natural History (Zoology), Supplement 4, 1-245.

Hayward, B. W., Grenfell, H. R., Ried, C. M. and Hayward k, A. 1999. Recent New Zealand shallow-water benthic foraminifera: taxonomy, ecologic distribution, biogeography, and use in paleoenvironmental assessment. Institute of Geological and Nuclear Sciences monographs, 21, 1-264.

Hayward, B. W., Holzmann, M., Grenfell, H. R., Pawlowski J. and Triggs, C. M. 2004. Morphological distinction of molecular types in Ammonia - towards a taxonomic revision of the world has most commonly misidentified foraminifera. Marine Micropaleontology, 50, 237 271.

Heron-Allen, E. and Earland, A., 1930. The foraminifera of the Plymouth District. Journal of the Royal Microscopical Society, 50 (3), 46-84.

Hofker, J., 1927. Foraminifera of the Siboga Expedition. Part 1, Siboga Exped. Monogr. 4, 1-78. 
Hofker, J., 1951. The Foraminifera of the Siboga expedition. Part III. Siboga-Expeditie. Monographie Va. Leiden: E. J. Brill. 1-513.

Höglund, H., 1947. Foraminifera in the Gullmar Fjord and the Skagerak. Zoologiska Bidrag från Uppsala, 2: 1-328.

Horton, B.P., Culver, S.J., Hardbattle, M.I.J., Larcombe, P., Milne, G.A., Morigi, C., Whittaker, J.E. and Woodroffe, S. A., 2007. Reconstructing Holocene sea-level change for the central Great Barrier Reef (Australia) using subtidal foraminifera. Journal of Foraminiferal Research, 37, 327-343.

Hottinger, L., Halicz, E. and Reiss, Z., 1993. Recent foraminiferida from the Gulf of Aqaba, Red Sea. Slovenska Akademija Znanosti in Umetnosti, Ljubljana, 33.

Hughes, G. W., 1977. Recent Foraminifera from the Honiara Bay area, Salomon Islands. Journal of Forarniniferal Research, 7, 45-57.

Hussain, S.M., Krishnamurthy, R. Gandhi, M. S., Ilayaraja, K. Ganesan, P. and Mohan, S. P., 2006. Micropaleontological investigations of tsunami sediments of Tamilnadu and Andaman Islands. Current Science. 91 (12), 1655- 1667.

Hyams, O., Almogi-Labin, A. and Benjamini, C., 2002. Larger foraminifera of the southeastern Mediterranean shallow continental shelf off Israel. Israel Journal of Earth Science, 51, 169-179.

Ishman, S, E., Graham, L. and D’Ambrosio, J., 1997. Modern Benthic Foraminifer Distributions in Biscayne Bay: Analogs for Historical Reconstructions. United State Geological Survey, Reston, File Report, 97-34.

Issa, B. M., 2010. Depositional environments and Biofacies of Selected Sediments, North Basrah. Jour. Basrah Research, Science, 36 (5), 1-14.

Javaux, E. J. and Scott, D. B., 2003. Illustration of modern benthic foraminifer from Bermuda and remarks on distribution in other subtropical/ tropical areas. Palaeontologia Electronica, 6(1), 1-29.

Jones, R.W., 1994. The Challenger Foraminifera. Journal of Evolutionary Biology, 9(1), 124-124

Jorissen, F.J., 1987. The distribution of benthic foraminifera in the Adriatic Sea. Marine Micropaleontology. 12, 21-48.
Jumnongthai, J., 1980. Recent foraminifera from southern Thailand. Geology Survey Paper, 1. 1- 21.

Kaladhar, R, Kamalakaran, S, Varma, K.U. and Bhaskara Rao, V. 1990. Recent foraminifera from nearshore shelf, south of Visakhapatnam, east coast of India. Indian Journal of Marin Science, 19, $71-73$.

Kaminski, M.A., 2004. The Year 2000 Classification of the Agglutinated Foraminifera. In: Bubik, M., Kaminski, M.A., (ed.) Proceedings of the sixth International Workshop on Agglutinated Foraminifera, Grzybowski Fondation Special Publication, 8, 237-255.

Kaminski, M.A., Aksu, A., Box, M., Hiscott, R.N., Filipescu, S. and Al-Salameen, M., 2002. Late Glacial to Holocene benthic foraminifera in the Marmara Sea: implications for Black Sea Mediterranean Sea connections following the last deglaciation. Marine Geology, 190, 162-202.

Keyzer, F. G., 1953. Reconsediration of the so-called Oligocene fauna in the asphaltic deposite of Buton (Malaya Archiopelago), 2. Young Neogene foraminifera and calcareous algae. Leidsche Geologische Meded-Lingen, 17, 259-293.

Khare, N., 1992. A study of foraminifera in surface and subsurface sediments from the shelf region off Karwar and their paleoclimatic significance. Unpublished PhD Thesis, Goa University, India.

Kisel'man, E. N., 1972. Verkhnemelovy I Paleosenovye foraminifery novogo roda Spiroplectinela (Upper Cretaceous and Paleocene new foraminiferal genus Spiroplectinella). Trudy Saibirskogo NauchnoIssledovatel'skogo Instituta Geologii Geofiziki I Mineral'nogo Syrya (SNIIGGIMS) Ministerstva Geologii Okhrany Nedr SSSR. Novosibirsk, 146: 134-140.

Koukousioura, O., Triantaphyllou, M. V., Dimiza, M. D., Pavlopoulos, K., Syrides, G. and Vouvalidis, K., 2012. Benthic foraminiferal evidence and paleoenvironmental evolution of Holocene coastal plains in the Aegean Sea (Greece). Journal Quaternary International, 261, 105-117.

Kumar, V., Manivannan, V. and Ragothaman, V., 1990. Distribution and species diversity of recent foraminifera from the Thamirabarani River estuary, Punnaikkayal, Tamil Nadu. Journal of Paleontological Society of India, 35, 53- 60. 
Kurbjeweit, F., Hemleben, Ch., Schmiedl, G., Schiebel, R., Pfannkuche, O., Wallmann, K. and Schafer, P., 2000. Distribution, biomass and diversity of benthic foraminifera in relation to sediment geochemistry in the Arabian Sea. Deep-Sea Research, II, 47(14), 2913-2955.

Lacroix, E., 1938. Revision du genre Massilina.Bulletin de I'institut Oceanographique Monaco, 754, 1-11.

Lacuna M. L. D. G., Masangcay S. I. G., Orbita M. L. S. and Torres M. A. J., 2013. Foraminiferal assemblage in Southeast coast of Iligan Bay, Mindanao, Philippines. Aquaculture, Aquarium, Conservation and Legislation International Journal of the Bioflux Society, 6 (4), 303-319.

Lagoe, M. B., 1977. Recent benthonic foraminifera from the Central Arctic Ocean. Journal of Foraminiferal Research, 7, 106-129.

Lamarck, J.B., 1804. Suite des mémoires sur les fossils des environs de Paris. Annales Muséum National d'Histoire Naturelle. 1, 475-475.

Lamarck, J.B., 1816. Histoire naturelle des animaux sans vertèbres. Verdière, Paris, tome 2, 1-568.

Langer, M. R., 1992. New recent foraminiferal genera and species from the lagoon at Madang, Papua New Guinea. Journal of Micropalaeontology, 11, 85-93.

Lankford, R. R. and Phleger, F. B., 1973. Foraminifera from the nearshore turbulent zone, western North America. Journal of Foraminiferal Research, 3, 101-132.

Larsen, A. R., 1976. Studies of recent Amphistegina, taxonomy and some ecological aspects. Israel Journal of Earth Sciences, 25, 1-26.

Le Calvez, Y., 1949. Revision des foraminiferes Lutetiens du Bassin de Paris. II Rotaliidae et families affines. Memoires du Service de la Carte Geologique detaillee de la France, 1-54.

Le Calvez, Y. and Le Calvez, J., 1958. Répartition des foraminiféres dans la Baie de Villefrance, I. Miliolidae. Annales de L>Institut Océanographique, 35, 159- 234.

Leiter, C., 2008. Benthos-Foraminiferen in Extremhabitaten: Auswertung von METEORExpeditionen vor Namibia. PhD Thesis, LudwigMaximilians-Universitaet, Munich, Germany, 103pp.
Leroy, D. and Levinson, S.A., 1974. A deep-water Pleistocene microfossil assemblage from a well in the northern Gulf of Mexico. Micropaleontology, 20, 1-37.

Levy, A., Poignant, A., Rosset-Moulinier, M. and Rouvillois. A., 1975. Sur quelques foraminifères actuels des plages de Dunkerque et des environs: néotypes et espèces nouvelles. Revue de Micropaléontologie, 17, 171-181.

Linné, C., 1758. Systema naturae per regna tria naturae, secundum classes, ordines, genera, species, cum characteribus, differentiis, synonymis, locis. G. Engelmann (Lipsiae). 10, 1-824.

Lioyd, J. M., 2006. Modern distribution of benthic foraminilcra from Disko Bugt, West Greenland. Journal of foraminiferal Research, 36(4), 315-331.

Loeblich A. R. and Tappan, H., 1953. Studies of Arctic foraminifera. Smithsonian Miscellaneous Collections, 121, 1-150.

Loeblich, A.R. and Tappan, H., 1964. Sarcodina, chiefly "Thecamoebians" and foraminifera (2 vols.). in: Moore, R. C. (eds.), Treatise on Invertebrate Paleontology, Protista 2, part C, Geological Society of America and Kansas University Press, 900pp.

Loeblich, A.R. and Tappan, H., 1964. Rupertlanella, newname of Pseudotriloculina Rasheed. 1971, non cherif, 1970 (Miliolacea). Journal of Foraminiferal Research, 15, 52.

Loeblich, A. R. and Tappan. H., 1988. Foraminiferal genera and their classification. Van Nostrand Reinhold, New York, 970pp.

Luczowska, E., 1974. Miliolidae (Foraminiferid) from the Miocene of Poland, Part II. Biostratigraphy, paleoecology and systematic. Acta Palaeontologica Polonica 19:3-176.

Madkour, H. A., 2013. Recent benthic foraminifera of shallow marine environment from the Egyptian Red Sea coast. Global Advanced Research Journal of Geology and Mining Research, 2(1), 5-14.

Majewski, W., Lecroq, B., Sinniger, F. and Pawlowski, J., 2007. Monothalamous foraminifera from Admiralty Bay, King George Island, West Antarctica. Polish Polar Research. 28, 187-210.

Maliker, Y., 2010. Western Mediterranean shelf foraminifera: Recent distribution, Holocene sea- 
level reconstructions, and paleoceanographic implications. $\mathrm{PhD}$ dissertation, Hamburg University, 169pp.

McCloskey, B., 2009. Foraminiferal responses to arsenic in a shallowwater hydrothermal system in Papua New Guinea and in the laboratory. PhD Dissertations, University of South Florida, 425pp.

Melis, R. and Violanti, D., 2006. Foraminiferal biodiversity and Holocene evolution of the Phetchaburi Coastal area (Thailand Gulf). Marine Micropaleontology, 61, 94-115.

Mendes, I., Gonzalez, R., Dias, J. M. A., Lobo, F. Martins V., 2004. Factors influencing recent benthic foraminifera distribution on the Guadiana shelf (Southwestern Iberia). Marine Micropaleontology, 51(1-2), 171-192.

Mercau, J. R., Laprida, C., Chandler, D. D. E., Lopez, R. A. and Marcomini, Y. S., 2011. Modern foraminifera from coastal settings in northern Argentina: implications for the paleoenvironmental interpretation of mid Holocene littoral deposits. Modern foraminifera from coastal settings, northern Revista Mexicana de Ciencias Geologicas, 28, 45-64.

Meriç, E., Avşar, N. and Bergin, F., 2004. Benthic foraminifera of Eastern Aegean Sea (Turkey) systematics and autoecology. Turkish Marine Research Foundation and Chamber of Geological Engineers of Turkey, Publication No. 18, 306pp.

Meriç, E., Avşar, N., Nazik, A., Yokeş, B., Ergin, M., Eryılmaz, M., YücesoyEryılmaz, F., Gökaşan, E., Suner, F., Tur, H, Aydin, Ş. and Dinçer, F., 2009. Factors controlling formation of benthic foraminifera, ostracod, mollusc assemblages and sediment distribution of the geochemistry in the Dardanelles Strait. Geology Bulletin of Turkey, 52 (2), 155-216.

Milker, Y. and Schmiedl. G., 2012. A taxonomic guide to modern benthic shelf foraminifera of the western Mediterranean Sea. Palaeontologia Electronica, 15 (2), 16A, 134p.

Milker, Y., Schmiedl, G., Betzler, C., Römer, M., Jaramillo-Vogel, D. and Siccha, M., 2009. Distribution of recent benthic foraminifera in neritic carbonate environments of the Western Mediterranean Sea. Marine Micropaleontology, 70, 207-225.
Miller, D. N., 1953. Ecological study of the Foraminifera of Mason Inlet, North Carolina. - Contribution from the Cushman Laboratory for Foraminiferal Research, 4 (2), 41-63.

Millett, F. W., 1898. Report on the Recent Foraminifera of the Malaya Archiopelahgo collected by Mr. a. Durrand, F. R. M. S., Journal of Royal Microscopical Society, 1898:258-269.

Montagu, G., 1803. Testacea Brittanica or Natural History of British Shells Marine, Land and Fresh Water, Including the Most Minute. J.S. Hollis, Romsey.

Montfort, P. denys de., 1808. Conchyliologie Systematique et Classification Methodique des Coquilles, Vol. 1. Paris: F. Schoell.

Morigi, C., Jorissen, F.J., Fraticelli, S., Horton, B.P., Principi, M., Sabbatini, A., Capotondi, L., Curzi, P.V. and Negri, A., 2005. Benthic foraminiferal evidence for the formation of the Holocene mudbelt and bathymetrical evolution in the central Adriatic Sea. Marine Micropaleontology, 57, 2549.

Murray, J. W., 1969. Recent foraminif era from the Atlantic continental shelf of the United States. Micropaleontology, 15, 401-419.

Murray, J. W. 1970. Foraminifers of the Western Approaches to the English Channel. Micropaleontology, 16, 471-85.

Murray, J. W., 2003. An illustrated guide to the benthic foraminifera of the Hebridean shelf, west of Scotland, with notes on their mode of life. Paleaeontologia Electronica, 5 (1), 1-31.

Natsir, S. M. and Muchlisin, Z. A., 2012. Benthic foraminiferal assemblages in Tambelan Archipelago, Indonesia. Aquarium, Conservation and Legislation International Journal of the Bioflux Society, 5, 259-264.

Neugeboren, J. L., 1850. Foraminiferen von FelsoLapugy: zweiter Artikel. Verhandulungen und Mittheilungen des Siebenburgischer Verein fur Naturwissen-schaften zu Hremannstadt, 1, 118127.

Nigam, R., Setty, M.G.A.P. and Ambre, N.V., 1979. A checklist of benthic foraininiferids from the inner shelf of Dabhol-Vengurla region, Arabian Sea. Journal of Geological Society of India, 20, 244-247. 
Nobes, K. and Uthicke, S., 2008. Benthic foraminifera of the Great Barrier Reef, A guide to speeies potentially useful as water quality indicators. Australian Inst. of Marine Sci., Townsvillc, 38pp.

Nuglisch, K., 1985. Foraminiferen - marine Mikroorganismen. Die neue Brehm-Bücherei, Wittenberg. 176pp.

Oflaz, S. A., 2006. Taxonomy and Distribution of the Benthic Foraminifera in the Gulf of Iskenderun, Eastern Mediterranean. Unpublished M.Sc. Thesis, Middle East Technical University, Ankara, $306 \mathrm{p}$.

Orbigny, A. d'., 1826. Tableau methodique de la classe des Cephalopodes Annal. Sci. Natur. 7, 245-314.

Orbigny, A. d'., 1839. Foraminiferes, in Ramon de la Sagra, Histoire physique, politique et naturelle de file de Cuba. Paris, Arthus Bertrand.

Orbigny, A. d'., 1846. Foraminiferes Fossiles Du Bassin Tertiaire De Vienne (Autriche). Gide et Comp, Libraires- Editeurs, Paris, Gide et Comp.

Parker, F. L., 1958. Eastern Mediterranean foraminifera. Reports of the Swedish Deep-Sea Expedition, Sediment Cores from the Mediterranean Sea and the Red Sea, 8, 217-285.

Parker J. H., 2009. Taxonomy of foraminifera from Ningaloo Reef, Western Australia. Memoirs of the Association of Australasian Palaeontologists, 36, 1-810.

Parr, W. J., 1941. A new genus, Planulinoides, and some species of foraminifera from South Australia. Mining and Geological Journal, 2, 177.

Parr, W. J., 1945. Recent foraminifera from Barwon Heads, Victoria. Proceedings of the Royal Society of Victoria, 56, 189-227.

Perconig, E., 1954. Note paleontologiche Sulla zona costiera di Agrigento (Sicilia). Contributi di Scienze Geologiche con particolare riguardo all'Italia central, 3, 91-98.

Phleger, F. B., 1965. Living benthic foraminifera from coastal marsh, southwestern Florida. Bol. Soc. Geol. Mexicana, 28(1), 45-60.

Phleger, F. B. and Parker, F. L., 1951. Ecology of foraminifera, northwest Gulf of Mexico, Part II, Foraminifera species. Geological Society of America Memoir, 46, 1-59.
Ragothaman, V. and Kumar, V., 1985. Recent foraminifera off the coast of Rameshwaram, Palk Bay, Tamil Nadu. Bulletin of the Geological, Mining and Metallugical Society of India, 97-121.

Rana, S. S., 2009. Study of foraminiferal distribution in surface and subsurface sediments off central east coast of India and their paleoecological significance. Published PhD Thesis, Department of Marine Science Goa University, Goa, India.

Rao, K. K., 1970. Forminifera of the Gulf of Cambay. Journal of Bombay Naturai History, 66: 584-596.

Rao, K. K., Sivadas, P., Narayanan, B. Jayalakshmi, K.V. and Krishnan Kutty, M. 1987. Distribution of foraminifera in the lagoons of certain islands of the Lakshadweep Archipelago. Arabian Sea. Indian Journal of Marine Science, 16, 161-178.

Rao. T.V. and Rao, M. S., 1974. Recent foraminifera of Suddagadda estuary, east coast of India. Micropaleontology, 20, 398-419.

Rasmussen, T. L., 2005. Systematic paleontology and ecology of benthic foraminifera from the Plio- Pleistocene Kallithea Bay section, Rhodes, Greece. Cushman Foundation for Foraminiferal Research Special Publication, Y13, 39, 53-157.

Reichel, M., 1937. Etude sur les Alvéolines, II. Schweizerische Paläontologische Abhandlung, 59 (3), 95-147.

Reiss, Z., 1963. Reclassification of perforate foraminifera. Bulletin of the Geological Survey of Israel, 59, 1-111.

Renema, W., 2003. Foraminifera on reefs around Bali (Indonesia). Zoologische Verhandelingen. 345, 337-366.

Reuss, A. E., 1850. Neues Foraminiferen aus den Schichten des osterreichischen Tertiarbeckens. Denk-schriften der Kaiserlichen Akademie der Wissenschaf-ten, MathematischNaturwissenschaftliche Classe, 1, 365-390.

Rocha, A. T. and Ubaldo, M. L., 1964. Nota Sobre of foraminifera recents da areias das praias dejampor (Damao) e de Baga Goa. Garcia de orto (lisaboa), 12, 645-650.

Sabbatini, M., Capotondi, L., Curzi, P. V. and Negri, A., 2005. Benthic foraminiferal evidence for the formation of the Holocene mud-belt and bathymetrical evolution in the central Adriatic 
Sea. Marine Micropaleontology, 57, 25-49.

Said, R., 1949. Foraminifera form the northern Red Sea. Special Publication Cushman Laboratory for Foraminiferal Research, 26, 1-44.

Said, R., 1950. Additional foraminifera from the northern Red Sea. Contribution from the Cushman Laboratory for Foraminiferal Research, 1, 5-9.

Saidova. Kh. M., 1975. Bentosnye Foraminifery Tikhogo Okeana (Benthonic foraminifera of the Pacific Ocean). 3 vol. Moscow: Institute Okeanologii P. P. Shirshova, Akademiya Nauk SSSR.

Saidova. Kh. M., 1981. Osovermennom sostoyanii sistemy nadvidykh taksonov Kaynozoyskikh Bentosnkh Foraminifer (On an up-todate system of supraspecific taxonomy of Cenozoic Benthonic foraminifera) Moscow: Institute Okeanologii P. P. Shirshova, Akademiya Nauk SSSR.

Samir, A. M., Abdou, H. F., Zazou, S. M. and ElMenhawey, W. H., 2003. Cluster analysis of recent benthic foraminifera from the northwestern Mediterranean coast of Egypt. Revue de Micropaleontologie, 46, 111-130.

Sarkar, S. D. S. and Gupta, A. K., 2009. Late Quaternary benthic foraminifera from Ocean Drilling Program Hole 7I6A, Maldives Ridge, southeastern Arabian Sea. Micropaleontology, 55 (1), 23- 48.

Sgarrella, F. and Moncharmont Zei, M., 1993. Benthic foraminifera of the Gulf of Naples (Italy): systematics and autoecology. Bollettino Della Società Paleontologica Italiana, 32 (2), 145-264.

Schlumberger, C. 1893. Note sur les genres Trillina et Linderina, Bulletin de la Societe Geologique de France, sen. 3 (21), 118-123.

Schroeter, J.S., 1783. Einleitung in die Conchilienkenntnis nach Linné, Erster Band. Gebauer, J.J, Halle.

Schultze, M. S., 1854. Uber den Organismus der Polythalamina (Foraminiferen) nebset Bermerkungen Uber die Rhizopoden im Allgemeinen. Leipzig: Wilhelm Engelmann.

Schwager, C., 1876. Saggio di una classificazion dei foraminiferei avuto riguardo alle loro famiglie naturali. Bulletino R. Comitato Geologico d'Italia, 7:475-485.
Schwager, C., 1877. Quadro del proposto Sistema di classificazion dei foraminiferi con guscio, Bulletino R. Comitato Geologico d'Italia, 8, 1827.

Schumacher, S., Jorissen, F. J., Dissard, D., Larkin, K. E. and Gooday, A. J., 2007. Live (Rose Bengal stained) and dead benthic foraminifera from the oxygen minimum zone of the Pakistan continental margin (Arabian Sea). Marine Micropaleontology, 62, 45-73.

Scott, D. B. and Hengstum, P. J. V., 2011. Ecology of foraminifera and habitat variability in an underwater cave: distinguishing anchialine versus submarine cave environments. Journal of Foraminiferal Research, 41(3), 201-229.

Seears, H., 2011. Biogeography and phylogenetics of the planktonic foraminifera. $\mathrm{PhD}$ thesis, University of Nottingham, United Kingdom, P. 76-77.

Silvestri, A., 1923. Lo stipites Della Elissoforme ele sue affinita. Memorie Della Pontificia Accademia Della Scienze, Nuovi Lincei, ser. 2: 231-270.

Sen Gupta, B. K., 1971. The benthonic foraminifera of the Tail of the Grand Banks. Micropaleontology, 17(1), 69-98.

Setty M. G. A. P. and Nigam, R., 1980. Microenvironment and anomalous benthic foraminiferal distribution within the neritic regime of the Dabhol-Vengurla sector (Arabian Sea). Revista Italianade Paleontologia and Stratigrafia, 417-428.

Sgarrella, F. and Moncharmont Zei, M., 1993. Benthic foraminifera in the Gulf of Naples (Italy): systematics and autoecology. Bollettino Della Societa Paleontologica Italiana, 32 (2), 145-264.

Shareef, N. A. and Venkatachalapathy, V., 1988. Foraminifera from the shore sands of Bhaktal and Devgad Islands, west coast of India. Journal of Geological Society of India, 31, 432-441.

Steinker, D. C., 1980. Nearshore foraminifera from Bermuda. The Compass, 57, 129-148.

Stubbings, H. G., 1939. Stratification of biological remains of marine deposits of the Arabian Sea. British Museum, (Nat. Hist.), John Murray Expedition, 3(3), 159-192.

Suhartati, M. and Muchlisin, Z. A., 2012. Benthic foraminiferal assemblages in Tambelan 
Archipelago, Indonesia. Aquarium, Conservation and Legislation International Journal of the Bioflux Society, 5(4), 259-264.

Terquem, O., 1875. Essai sur le classement des animaux qui vivent sur la plage el dans les environs de Dunquerque. Easc, 1. Paris, pp. 1-54.

Terquem, O., 1876. Essai sur le classement des animaux qui vivent sur la plage et dans les environs de Dunquerque. deuxieme fascicule, 55-100.

Terquem, O., 1882. Les foraminiferes de 1" Eocene environs de Paris. Memoires de la Societe Geologique de France, ser.3, 2 (3), 1-193.

Todd, R., 1965. The foraminifera of the tropical Pacific collections of the «Albatross», 1899-1900, Part 4, Rotaliform families and planktonic families. United States National Museum Bulletin, 161, 1-139.

Todd, R. and Low, D., 1971. Foraminifera from the Bahama Bank west of Andros Island. United States Geological Survey Professional Paper, 683C: $1-22$.

Toefy, R., McMillan, I. K., und Gibbons, M. J., 2005. The foraminifera associated with the alga Gelidium pristoides, South Africa. African Invertebrates, 46, 1-26.

Van Voorthuysen, H. J., 1957. Foraminiferen aus dem Eemian (Riss-Würm interglazial) in der Bohrung Amersfoort 1 (Locus typicus). Mededelingen van der Geologische Stichting, 11, 27-39.

Vedantam, D. and Rao, M.S. 1970. Recent foraminifera from off Pentakota, east coast of India. Micropaleontology 16 (3), 325-344.

Wiesner, H., 1920. Zur Systematik der Miliolideen. Zoologischhes Anzeiger 51, 13-20.

Wiesner, H., 1923. Die Miliolideen der östlichen Adria. The author, Prag Bubanec. Albani, A. D., 1974. New benthonic foraminiferida from Australian waters. Journal of Foraminiferal Research, 4, 3537.
Wiesner, H., 1931, Die Foraminiferen der deutschen Südpolar-Expedition 1901-1903. In: Drygalski, E. von, (ed.) Deutsche Südpolar-Expedition 19011903, im Auftrage des Reichsministeriums des Innern: 20 (= Zoologie, Band 12), 49-165. Walter DeGruyter and Co. (Berlin and Leipzig).

Williamson, W. C., 1858. On the recent foraminifera of Great Britain. The Ray Society, London, 1-107.

Wisshak, M. and Rueggeberg, A., 2006. Colonisation and bioerosion of experimental substrates by benthic foraminiferans from euphotic to aphotic depths (Kosterfjord, SW Sweden). Facies, 52, $1-17$.

Wright, j., 1900. The foraminifera of $\operatorname{dog}>\mathrm{s}$ Bay, Connemara. Irisb Naturalist, 9: 50-55.

Yalcin, H., Meric, E, Avsar, N., Tctiker, S., and Dincer, F., I., 2006. Recent colored benthic foraminifers and their mineralogical and geochemical features in the Aegean and Southwestern Mediterranean Coasts. Geological Bulletin of Turkey, 49 (2), 2951.

Yanko, V., 1995. Benthic foraminifera as indicators of heavy metal pollution along Israeli Coasts. In: Yanko, V. (ed.) Avicenna (AVI CT92-0007), benthic foraminifera as indicators of heavy metal pollution-a new kind of biological monitoring for the Mediterranean. Task 5, 58-152.

Yanko, V., avsar, N., Sanvoisin, R., Spezzaferri, S, Meric, E. and Basso, D., 1993. Foraminiferal study: Taxonomy, distribution. Task 9, 31-33.

Yassini, I. and Jones B. G., 1995. Recent foraminifera and ostracoda from estuarine and shelf environments on the southeastern coast of Australia. University of Wollongang Press, New South Wales, Wollongang, 484pp.

Zheng, S. Y., 1979. The recent foraminifera of the Xisha Island, Guangdong Province, China, II. Studia Marina Sinica, 15, 101-232. 